\title{
Parabolic Trough Reference Plant for Cost Modeling with the Solar Advisor Model (SAM)
}

Technical Report NREL/TP-550-47605 July 2010

C. Turchi

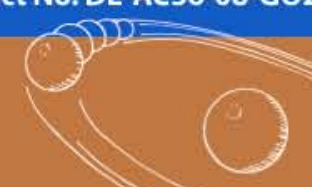




\section{Parabolic Trough Reference}

Plant for Cost Modeling with the Solar Advisor Model (SAM)

C. Turchi

Prepared under Task No. SS01.2340

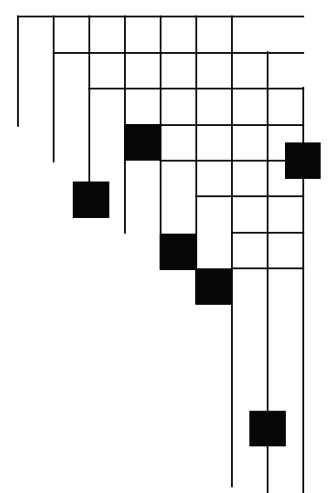




\section{NOTICE}

This report was prepared as an account of work sponsored by an agency of the United States government. Neither the United States government nor any agency thereof, nor any of their employees, makes any warranty, express or implied, or assumes any legal liability or responsibility for the accuracy, completeness, or usefulness of any information, apparatus, product, or process disclosed, or represents that its use would not infringe privately owned rights. Reference herein to any specific commercial product, process, or service by trade name, trademark, manufacturer, or otherwise does not necessarily constitute or imply its endorsement, recommendation, or favoring by the United States government or any agency thereof. The views and opinions of authors expressed herein do not necessarily state or reflect those of the United States government or any agency thereof.

Available electronically at http://www.osti.gov/bridge

Available for a processing fee to U.S. Department of Energy and its contractors, in paper, from:

U.S. Department of Energy

Office of Scientific and Technical Information

P.O. Box 62

Oak Ridge, TN 37831-0062

phone: 865.576 .8401

fax: 865.576 .5728

email: mailto:reports@adonis.osti.gov

Available for sale to the public, in paper, from:

U.S. Department of Commerce

National Technical Information Service

5285 Port Royal Road

Springfield, VA 22161

phone: 800.553.6847

fax: 703.605.6900

email: orders@ntis.fedworld.gov

online ordering: http://www.ntis.gov/ordering.htm 


\section{Parabolic Trough Reference Plant for Cost Modeling with the Solar Advisor Model}

\section{Summary}

This report describes a component-based cost model developed for parabolic trough solar power plants. The cost model was developed by the National Renewable Energy Laboratory (NREL) with assistance from WorleyParsons Group Inc. for use with NREL's Solar Advisor Model (SAM). This report includes an overview and explanation of the model, two summary contract reports from WorleyParsons, and an Excel spreadsheet for use with SAM 2010-04-12. The cost study uses a reference plant with a 100-MWe capacity and six hours of thermal energy storage. Wet-cooling and dry-cooling configurations are considered. The spreadsheet includes capital and operating costs by component, e.g., mirrors, heat transfer fluid, operators, etc., to allow users to estimate the impact of changes in component costs. Costs estimated by WorleyParsons were adjusted for a slight change in plant size and relocation to southwest Arizona. The solar field costs estimated by WorleyParsons were reduced based on input from trough developers. The spreadsheet also allows users to estimate the costs of different-size plants and to take into account changes in commodity prices. The Excel spreadsheet can be downloaded at https:/www.nrel.gov/analysis/sam/templates.html.

\section{Background and Motivation}

The Solar Advisor Model was developed to assist solar stakeholders in assessing the performance and cost of photovoltaic (PV) and concentrating solar power (CSP) electricity generation systems. SAM incorporates modules that estimate the performance of different PV and CSP systems based on design parameters and climate files that include solar and weather data for the selected location. The current SAM version, released in April 2010, is available at https://www.nrel.gov/analysis/sam/. SAM also includes algorithms to estimate the levelized cost of electricity (LCOE) based on a variety of selectable financial and incentive assumptions. Essential inputs of the LCOE calculations include the estimated installed cost and operating cost of the technology.

Parabolic troughs represent the most mature of the different CSP technologies and more than 500 MW of trough plants are operating in the United States and Spain. In addition, several gigawatts $(\mathrm{GW})$ of trough plants have been proposed for locations around the world [1]. Because of this, the parabolic trough model is one of the more commonly used components within SAM. The trough plant model within SAM uses a set of cost inputs to calculate the total installed cost and LCOE of the specific plant case input by the SAM user.

Prior to October 2009, NREL's default cost inputs for the parabolic trough were based on references dating back as far as 1999, as well as more recent discussions with developers and industry members. Knowing that the 2009 release of SAM would be a major revision, NREL decided to undertake an update to the parabolic trough cost model. This update started by specifying conditions for a representative plant and contracting with an experienced engineering firm to perform a conceptual design and budgetary cost estimate for the facility. The desire to update the parabolic trough cost model was further motivated by the fluctuations in commodity 
prices witnessed from 2007 to 2009. Simple corrections for inflation rate were not accurate for tracking yearly changes in system components such as steel and nitrate salt. The revised cost model was to tie different system components (e.g., heat-transfer fluid, nitrate salt, steel tanks and heat exchangers) to industry price indices that provide a better mechanism for tracking market price fluctuations.

\section{Approach}

NREL contracted with WorleyParsons Group, Inc. (Golden, CO) to perform a design and cost analysis of the representative trough plant. WorleyParsons' Renewable Energy Program includes comprehensive services related to all aspects of project development, environmental impact assessment, detailed design, procurement, construction and operations \& maintenance of renewable energy power plants. WorleyParsons' capability in CSP system engineering and design is exemplified by their history of engineering design and cost support for multiple renewable energy and conventional power projects in the United States and abroad.

NREL provided WorleyParsons with nominal design specifications for the reference plant, as outlined in Table 1. Using this guidance, WorleyParsons completed a conceptual design and cost assessment of a parabolic trough plant with wet cooling and optional dry cooling. The wetcooled plant represented the base case for the analysis; a dry-cooled plant with the same nominal capacity was also examined. WorleyParsons considers the confidence interval for this level of cost estimate to be $\pm 30 \%$.

Table 1. Baseline trough plant specifications provided to WorleyParsons

\begin{tabular}{|l|c|}
\hline Baseline Plant Conditions & $100 \mathrm{MW}_{\mathrm{e}}$ \\
\hline Nameplate Capacity & 6 hours \\
\hline $\begin{array}{l}\text { Thermal Storage (operating time } \\
\text { at nameplate capacity) }\end{array}$ & 2.0 \\
\hline Solar Multiple & Synthetic oil \\
\hline Heat Transfer Fluid & Binary Na/K nitrate salt \\
\hline Storage Fluid & Indirect "2-tank" system [6] \\
\hline Thermal Storage System & Duperheated steam Rankine cycle with wet cooling \\
\hline Power Cycle & Daggett, CA \\
\hline Location & Air-cooled system of same nominal capacity \& \\
\hline \multicolumn{2}{|c|}{ storage } \\
\hline
\end{tabular}

In addition to the contract work provided by WorleyParsons, NREL continued a dialog with various solar developers and engineering/construction firms. In general, discussions with industry indicated equivalent or slightly lower costs than reported by WorleyParsons. Some of the difference was attributed to developers' vertical integration or negotiation of final prices, 
although it is also likely that scope and accounting practices are not completely consistent. The resulting values for a hypothetical $100-\mathrm{MW}_{\mathrm{e}}$ net plant are shown in Table 2 . These values consider input from WorleyParsons as well as from other solar industry members.

The primary purpose of the WorleyParsons contract was to develop a line-item cost model that SAM users could manipulate to represent cases of interest. The costs shown in Table 2 are for a reference plant located in southwest Arizona with merit-shop labor and may not be representative of other locations or markets within the United States. As in previous versions of SAM, users are cautioned to review the inputs and determine whether they are appropriate for their specific analysis.

Table 2. Cost inputs used for SAM Reference case Parabolic Trough plant.

\begin{tabular}{|c|c|c|}
\hline Direct Cost (DC) Category & $\begin{array}{l}\text { Value used in } \\
\text { SAM }\end{array}$ & Units \\
\hline Site Improvements & $25^{*}$ & $\$ / \mathrm{m}^{2}$ \\
\hline Solar Field & 295 & $\$ / \mathrm{m}^{2}$ \\
\hline HTF System & 90 & $\$ / \mathrm{m}^{2}$ \\
\hline Storage & 80 & $\$ / \mathrm{kWh}-\mathrm{t}$ \\
\hline Fossil Backup & 0 & $\$ / \mathrm{kW}$ \\
\hline Power Plant (wet-cooled), based on turbine gross & 940 & $\$ / \mathrm{kW}$ \\
\hline Power Plant (dry-cooled), based on turbine gross & 1160 & $\$ / \mathrm{kW}$ \\
\hline Contingency & 10 & $\%$ of DC \\
\hline \multicolumn{3}{|l|}{ Indirect Cost Category } \\
\hline Engineer, Procure, Construct & 15 & $\%$ of DC \\
\hline Project, Land, Management & 3.5 & $\%$ of DC \\
\hline Sales Tax & 7.75 & $\%$ \\
\hline \multicolumn{3}{|l|}{ O\&M Cost Category } \\
\hline Fixed Annual Cost & 0 & $\$ / y r$ \\
\hline Fixed Cost by Capacity & 70 & $\$ / \mathrm{kW}-\mathrm{yr}$ \\
\hline Variable Cost by Generation & 3 & $\$ / \mathrm{MWh}$ \\
\hline Fuel Cost & 0 & \$/MMBTU \\
\hline \multicolumn{3}{|l|}{ Other } \\
\hline $\begin{array}{l}\text { Availability (based on } 2 \text {-week outage in January } \\
\text { plus } 7 \text { days forced outage per year) }\end{array}$ & 96 & $\%$ \\
\hline
\end{tabular}

* average value. Estimate is slightly higher for wet-cooled plant and slightly lower for a dry-cooled plant due to elimination of evaporation ponds

System Availability is used in SAM to reduce the annual generation that is estimated by plant design and climate data alone. In the case of a solar plant, daily output varies by season and the impact of an outage in summer is much greater than one in winter. The value of $96 \%$ assumes a 
two-week planned outage in January and seven days of forced outage throughout the year. The forced outage days assume an annual average daily output is lost. Forced outages are not weather related, but indicate some equipment-related failure.

\section{Wet-Cooled and Dry-Cooled Plant Results}

The WorleyParsons contract reports on the wet-cooled plant and dry-cooled plant are provided as Appendix A and B, respectively. Table 3 is a summary comparison of the two designs. The WorleyParsons cost analyses were performed for an Engineering, Procurement, and Construction Management (EPCM) project contract. As such, several typical project costs were not included in the WorleyParsons estimates - most notably, those normally associated with owner's costs. Typical owner's costs include permitting, land, legal fees, geotechnical and environmental surveys, taxes, interest during construction, and the owner's engineering and project management activities. In addition, WorleyParsons did not include sales tax in their analysis. These categories are accounted for in SAM under Indirect Capital Costs and are essential for calculating LCOE.

The bottom of Table 3 includes an estimate of Total Installed Cost and LCOE taken from SAM for the wet-cooled and dry-cooled designs. These estimates use the SAM cost values presented in Table 2, as explained above. The sizing parameters in SAM (e.g., solar field area, power block, reference insolation) were set to match the values in the WorleyParsons reports. Financial assumptions in SAM match those provided in the SAM Sample Parabolic Trough Systems file, i.e., $2.5 \%$ inflation rate, $8 \%$ loan rate, $8 \%$ real discount rate, 30 -year project life, $35 \%$ federal and $8 \%$ state tax rates, $15 \%$ required internal rate of return (IRR), Modified Accelerated Cost Recovery System (MACRS) depreciation, and 30\% investment tax credit (ITC). 
Table 3. Comparison of wet-cooled and dry-cooled parabolic trough plants in Daggett, CA, based on WorleyParsons Plant design.

\begin{tabular}{|c|c|c|c|}
\hline Design Parameters & $\begin{array}{l}\text { Wet-Cooled } \\
\text { Design }\end{array}$ & $\begin{array}{l}\text { Dry-Cooled } \\
\text { Design }\end{array}$ & $\%$ Change \\
\hline Power block net rating $\left(\mathrm{MW}_{\mathrm{e}}\right)$ & 103 & 103 & 0 \\
\hline Thermal energy storage at design point (hours) & 6.3 & 6.3 & 0 \\
\hline Design conditions DNI $\left(\mathrm{W} / \mathrm{m}^{2}\right)$ & 1000 & 1000 & 0 \\
\hline Design conditions wet-bulb temperature $\left({ }^{\circ} \mathrm{C}\right)$ & 21.8 & 21.8 & 0 \\
\hline Design conditions dry-bulb temperature $\left({ }^{\circ} \mathrm{C}\right)$ & 42.2 & 42.2 & 0 \\
\hline \multicolumn{4}{|l|}{ Size Parameters } \\
\hline Turbine gross rating $\left(\mathrm{MW}_{\mathrm{e}}\right)$ & 118 & 120.5 & $+2.1 \%$ \\
\hline Plant footprint (acres) & 1018 & 1024 & $+0.6 \%$ \\
\hline Solar Field area $\left(\mathrm{m}^{2}\right)$ & 987,540 & $1,062,750$ & $+7.6 \%$ \\
\hline Thermal storage media (metric tonnes) & 62,000 & 66,800 & $+7.8 \%$ \\
\hline Thermal storage size (MWh- $\mathrm{t})$ & 1988 & 2144 & $+7.8 \%$ \\
\hline \multicolumn{4}{|l|}{ Output values estimated by WorleyParsons } \\
\hline Annual net electricity generation (MWh) & 426,717 & 438,790 & $+2.8 \%$ \\
\hline Capacity factor (based on $103 \mathrm{MW}_{\mathrm{e}}$ net) & $47 \%$ & $48 \%$ & $+2.8 \%$ \\
\hline Annual water consumption $\left(\mathrm{m}^{3}\right)$ & $\begin{array}{c}1,530,000 \\
(1240 \text { acre- } \\
\mathrm{ft})\end{array}$ & $\begin{array}{c}114,000 \\
(90 \text { acre-ft) }\end{array}$ & $-93 \%$ \\
\hline $\begin{array}{l}\text { Design point parasitic: HTF circulation pumps } \\
\left(\mathrm{MW}_{\mathrm{e}}\right)\end{array}$ & 7.9 & 8.4 & $+6 \%$ \\
\hline Design point parasitic: Cooling system $\left(\mathrm{MW}_{\mathrm{e}}\right)$ & 2.0 & 3.6 & $+80 \%$ \\
\hline Design point parasitic: Total $\left(\mathrm{MW}_{\mathrm{e}}\right)$ & 15.0 & 17.6 & $+17 \%$ \\
\hline Annual O\&M costs & $\$ 11.8 \mathrm{M}$ & $\$ 11.7 \mathrm{M}$ & $-1 \%$ \\
\hline \multicolumn{4}{|l|}{$\begin{array}{l}\text { SAM Results using design and size parameters in } \\
\text { this table and cost values from Table } 1\end{array}$} \\
\hline Annual net electricity generation (MWh) & 414,500 & 419,100 & $+1.1 \%$ \\
\hline Total Installed Costs $\left(\$ / \mathrm{kW}_{\mathrm{e}}\right)$ & 8950 & 9,810 & $+10 \%$ \\
\hline LCOE $(\phi / \mathrm{kWh})$, nominal with $30 \%$ ITC & 18.4 & 19.7 & $+7 \%$ \\
\hline LCOE $(\phi / \mathrm{kWh})$, real with $30 \%$ ITC & 14.6 & 15.6 & $+7 \%$ \\
\hline
\end{tabular}

SAM case files were created with the Physical Trough Model to replicate as closely as possible the WorleyParsons' design assumptions. The SAM analysis was performed using the TMY3 climate file for Daggett, CA, because this was the dataset used by WorleyParsons. The TMY3 data have a slightly lower annual average insolation versus the TMY2 data for Daggett.

The SAM runs gave total energy generation about 3\% to $4 \%$ lower than that provided by WorleyParsons for both wet-cooling and dry-cooling cases. The difference is primarily due to 
NREL using a plant availability of $96 \%$, while WorleyParsons did not include plant availability in their estimate of annual net generation. Switching from wet to dry cooling raised plant installed cost by about $10 \%$ and LCOE by $7 \%$. LCOE does not increase as much as installed cost due to the greater annual energy generation of the dry-cooled plant. The dry-cooled plant produces more energy because the solar field and power block are oversized to maintain designpoint generation at high ambient temperature. At the lower ambient temperatures that characterize most of the year, this combination generates more energy than the slightly smaller wet-cooled plant.

The annual energy generation and associated capacity factors shown in Table 3are higher than NREL normally estimates for a trough plant having six hours of storage. This results from the conservative design approach taken by WorleyParsons in the ratio of solar field to turbine size. The ratio of energy supply of the solar field to energy use by the power block at a specified reference condition is known as the solar multiple. Even without storage, solar trough plants are normally designed with a solar multiple larger than 1.0 to allow the power block to run at design point under less than ideal solar conditions. With six hours of storage, a solar multiple of 2.0 has been shown by NREL to minimize LCOE under typical conditions. Using WorleyParsons' solar field and turbine size, SAM calculates a solar multiple of approximately 2.25 . The relatively high solar multiple leads to a higher total installed cost, although the effect on LCOE is less dramatic, and under certain conditions negligible, due to additional energy generation. WorleyParsons believes the difference can be explained by their treatment of thermal loses external to the troughs and guaranteed (WP) vs. expected (SAM) equipment performance.

One surprising finding is the dry-cooled plant occupies less land per MWh than the more efficient wet-cooled plant. This occurs because the additional solar field area required to maintain the net capacity of the dry-cooled plant is offset by elimination of over 60 acres of evaporation ponds.

\section{Water Consumption}

The primary reason for using dry cooling is to minimize water consumption. All thermoelectric power plants prefer to use wet cooling because this approach yields higher thermal-cycle efficiency. However, water may not be available or its usage may be prohibited or limited by policy. The WorleyParsons work found that a relatively small initial temperature difference (ITD) of $14^{\circ} \mathrm{C}$ in the air-cooled condenser (ACC) was the preferred design approach for drycooled parabolic trough plants. The smaller ITD means a more expensive ACC, but minimizes the additional solar field and turbine capacity needed to overcome the lesser efficiency of the dry-cooled plant.

Table 4 highlights a comparison of water consumption by the two plant designs. Switching to dry cooling reduces water consumption by more than $93 \%$ by eliminating the evaporative-cooling tower. Remaining water consumption for mirror washing and steam-cycle applications increase due to the lower plant efficiency, but these effects are overwhelmed by eliminating the cooling tower. In the WorleyParsons design, a small amount of makeup water is necessary to support a wet-surface air cooler to provide low temperature cooling water for turbine components. Annual water consumption for the two plants is also listed in terms of acre-ft of water used per acre of total plant area. This format provides a useful comparison to agricultural water consumption. 
Typical western crops such as cotton, alfalfa, and sugar beets require 2 to 4 feet of water for irrigation $[4,5]$, i.e., more than twice the water required by a wet-cooled plant and more than 22 times by a dry-cooled plant.

Table 4. Comparison of water consumption for wet-cooled and dry-cooled trough plants. See Table 3 for plant size information.

\begin{tabular}{|c|c|c|c|}
\hline $\begin{array}{l}\text { Water Usage (acre-ft per year) } \\
\text { Note: } 1 \text { acre-ft }=1233 \text { cubic meters }\end{array}$ & $\begin{array}{l}\text { Wet-Cooled } \\
\text { Design }\end{array}$ & $\begin{array}{l}\text { Dry-Cooled } \\
\text { Design }\end{array}$ & $\%$ Change \\
\hline Cooling tower makeup & 1165 & 3 & $-99.7 \%$ \\
\hline Blow-down quench and steam-cycle makeup & 23 & 24 & $+4 \%$ \\
\hline Steam-cycle makeup during startup & 13 & 19 & $+46 \%$ \\
\hline Mirror washing & 40 & 44 & $+10 \%$ \\
\hline Total & 1241 & 90 & $-93 \%$ \\
\hline Annual water consumption (acre-ft/acre) & 1.2 & 0.09 & $-93 \%$ \\
\hline
\end{tabular}

\section{Impact of Labor Cost}

Daggett, CA, has an excellent solar resource and has served as the CSP program's de facto representative location for several years. Although the resource and topography are attractive, the WorleyParsons analysis highlighted the relatively high labor rates in this region. Comparing the solar resource and labor rates for southern California and southwest Arizona indicates a significant reduction in installed cost and LCOE for a site in southwest Arizona. The NREL reference plant provided in the spreadsheet uses a southwest Arizona site. Relocation of the NREL CSP reference plant to SW Arizona also aligns with the historic use of Phoenix as the reference site for installed photovoltaic cost estimates. The reader should note that the WorleyParsons reports provided in the appendices use the higher Riverside, CA, union shop wage rates relevant for Daggett, CA. As described in the following section, NREL adjusted the WorleyParsons labor costs from southern California to southwest Arizona using data from the US Bureau of Labor. The Bureau of Labor statistics indicated a reduction of approximately $47 \%$ in labor rates (private industry, mean hourly wage, union labor, Riverside, CA versus nonunion Phoenix, AZ) [2].

WorleyParsons labor rates are based on an "all-in crew rate" for union labor in southern California that includes items which some developers may not consider labor. These overhead categories include rental equipment, field offices, temporary facilities, small tools, consumables, etc.; a complete listing is given in section 3.3.5 of the Appendix reports. Some of these labor overhead costs are fixed and not dependent on local payroll rates. Thus, as calculated by WorleyParsons, the reduction in "labor cost" by moving from California to Arizona is not equal to the $47 \%$ listed by the Bureau of Labor CA-AZ differential. To simplify labor rate corrections we shift a fraction of the labor costs into materials before applying the Bureau of Labor differential as described in the following section. This shift is also consistent with developer 
feedback that the fraction of solar field cost that is affiliated with labor is significantly less than reported by WorleyParsons.

For comparison, WorleyParsons also estimated labor using a "force account rate" that includes only payroll, fringe benefits, and statutory overheads. Accordingly the force account rate is substantially lower than the all-in crew rate. Discussion with solar developers suggests that developers may be using a labor rate closer to the force account rate and accounting for the items WorleyParsons considers labor overheads elsewhere. That is, the companies may utilize different labor accounting methods.

\section{Parabolic Trough Model Spreadsheet and NREL Reference Trough Plant}

The primary objective of the WorleyParsons contract was to help create a model framework that would allow SAM users to look at the cost impact of individual components of a typical parabolic trough plant. For example, mirror manufacturers wish to know how much of the total plant cost is due to the cost of the reflector materials. Secondly, the rapid fluctuations in commodity prices over the last two years highlighted the need to keep the cost model current by incorporating appropriate cost indices for the different cost components. The result of these objectives was the creation of a spreadsheet-based cost model for a hypothetical parabolic trough plant of 100-MW capacity with 6 hours of thermal energy storage, based partly but not entirely on the WorleyParsons work. The model allows users to update costs for changes in technology or markets. This spreadsheet, available for download at https://www.nrel.gov/analysis/sam/templates.html, is designed to interface with the Physical Trough Model in SAM. Users are encouraged to customize the spreadsheet model for their individual purpose. Guidelines for use are provided below and within the spreadsheet itself.

The spreadsheet includes cost indices to escalate component and labor costs for inflation and market factors. Cost indices in the spreadsheet model are based on the Chemical Engineering Plant Cost Index published monthly in Chemical Engineering Magazine and available online at http://www.che.com/. Additional cost indices are taken from the U.S. Bureau of Labor's Producer Price Index (PPI), which can be tracked on line at http://www.bls.gov/ppi/. The spreadsheet includes a PPI index for synthetic ammonia to represent the nitrate salt storage media in trough plants. This public index tracks the nitrogen fertilizer market; however, vendor data suggest it may not be an accurate surrogate for solar salt prices. Salt price has a large impact on overall storage costs and users are encouraged to check with vendors for these prices. A vendor-supplied estimate of historic solar salt prices is included. Users may also customize the spreadsheet by choosing alternative cost indices. Within the spreadsheet, a specific cost index is selected by changing the Matl cost esc Factor or Labor cost esc Factor.

The spreadsheet contains cost information for two trough plants: a "reference plant" and a "project plant." The reference plant (highlighted in yellow) is defined as a $100-\mathrm{MW}_{\mathrm{e}}$ trough plant with 6 hours of thermal energy storage located in southwest Arizona. The solar multiple was set to 2.0, and SAM was used to calculate the associated solar field size. The TMY3 climate file for Blythe, CA was selected as the best representation of southwest Arizona. Blythe sits on the California/Arizona border. If this climate file is not in your SAM database it can be downloaded from the TMY3 website by following the instructions on the SAM Climate Page. (As an alternative the user can use the Tucson TMY2 climate file included in SAM.) Because the 
WorleyParsons work did not exactly match these plant conditions, the line-item capital and labor cost values provided by WorleyParsons were adjusted as follows:

- Solar field, site preparation, and heat transfer fluid (HTF) system costs were scaled linearly to the smaller solar field area in the NREL reference plant.

- Thermal storage costs were scaled linearly to the smaller storage capacity in the NREL reference plant.

- Power block costs were scaled by the 0.7 power to the smaller power block in the NREL reference plant.

- Labor rates were adjusted to represent Arizona wage scales. This adjustment was made by comparing the mean hourly earnings for workers in the occupation category of Natural Resources, construction and maintenance from the U.S. Bureau of Labor. The adjustment compared Phoenix, AZ, and union-shop, LA-Long Beach-Riverside, CA, datasets from April 2008 [2].

- Several solar developers told NREL that labor accounts for less than $20 \%$ of their installed solar field cost. The WorleyParsons analysis indicates a labor contribution of $45 \%$ for an Arizona location and even higher for a California labor pool. As noted in the Impact of Labor section, some costs that WorleyParsons includes with labor do not scale with local labor rates. For the NREL reference plant, WorleyParsons' all-in crew labor costs were reduced by $40 \%$ and the costs were distributed over the materials categories. For consistency this shift of labor overhead to material overhead was applied to all direct cost categories, i.e., site preparation, solar field, power block, etc. Note that this adjustment reduces the labor fraction of the direct cost categories but does not change the overall installed cost. The implicit assumption is developers and WorleyParsons differ in how they account for certain cost categories.

- Discussion with solar field developers, including some who have recently built parabolic trough plants, indicated their estimated solar field costs were significantly less than that shown in the WorleyParsons reports. While different labor overhead rates could account for this discrepancy, those rates would impact all cost categories, not just the solar field and the other cost category estimates were comparable. NREL reduced the WorleyParsons site preparation and solar field costs by $25 \%$ to bring the final $\$ / \mathrm{m} 2$ number closer, although still slightly higher than, numbers reported by developers. Whether this adjustment represents the vertical integration of developers, conservative design on the part of WorleyParsons, newer collector technology, etc. is unclear. It likely is some combination of these factors. Nonetheless, NREL believes the values provided in the spreadsheet to be representative; however, as with any cost estimate users are cautioned to carefully examine solar field cost and distribution to determine if it is appropriate for your specific case.

WorleyParsons did not provide detailed operation and maintenance (O\&M) categories, but only a rollup of O\&M costs, as shown in Appendix A and B. Thus, the labor categories on sheet O\&MS were generated by relying on information from NREL's Excelergy spreadsheet model, which was based on data from the California SEGS plants. The total O\&M costs were manipulated to closely match the WorleyParsons rollup costs for the plant size and location used 
in the WorleyParsons analysis. Annual salary values used on the O\&M\$ sheet come from the U.S. Bureau of Labor under NAICS 221100, Electric Power Generation, Transmission and Distribution, May 2008. National mean values are shown in the spreadsheet. These values are adjusted within the spreadsheet to represent a workforce in different geographic regions [2].

As noted previously, WorleyParsons provided only the EPCM indirect costs and did not include an estimate of Owner's costs. General indirect cost categories are listed in the spreadsheet with NREL estimated values. Owner's costs include such items as permitting, land, legal fees, geotechnical and environmental surveys, taxes, interest during construction, and the owner's engineering and project management activities. For simplicity SAM uses only three indirect cost categories: (1) Engineer, Procure, Construct; (2) Project, Land, Misc.; and (3) Sales Tax. In SAM's default files, the combined indirect costs are approximately $25 \%$ of total direct + contingency costs. Because project costs can vary greatly and have a significant impact on total installed cost and LCOE, users are cautioned to review and revise these estimates, as appropriate.

The project plant provided in the spreadsheet (highlighted in orange) is intended to represent the user's specific scenario. The spreadsheet calculates the project plant costs by comparing its size to that of the reference plant. As supplied, the project plant is adjusted to match NREL's SAM default trough plant case.

Users can link the cost model spreadsheet to SAM 2010 through the Excel Exchange linkage. SAM allows users to connect any input variable in SAM to a cell or range of cells in a Microsoft Excel workbook. This feature allows users to use external spreadsheet-based cost and performance models to generate values for SAM input variables. A list of the exchange variables used in the cost model template is provided in Table 5. User-defined input variables can also share values with external workbooks. For example, User Variable 2 returns an estimate of annual utility costs to SAM. UV-2 can be divided by the annual generation to check if SAM's estimated Variable Cost by Generation is accurate. This extra step is required because Variable Cost by Generation requires SAM's estimate of annual generation which cannot be passed a priori to the spreadsheet. 
Table 5. Sent to/captured from variable list for SAM Excel Exchange.

\begin{tabular}{|c|c|c|}
\hline $\begin{array}{l}\text { SAM variables sent from SAM to } \\
\text { Excel }\end{array}$ & Excel cell & Comments \\
\hline Design gross output & h11 & \\
\hline Actual aperture & h12 & Total solar field aperture area \\
\hline TES thermal capacity & h13 & \\
\hline User Variable 1 & h15 & Cost reference year \\
\hline Inflation Rate & h16 & \\
\hline Row spacing & h18 & Used to estimate land area \\
\hline Aperture width, total structure & h19 & Used to estimate land area \\
\hline Sales Tax & $\mathrm{h} 20$ & \\
\hline User Variable 4 & h21 & Labor rate multiplier \\
\hline \multicolumn{3}{|c|}{ SAM variables captured by SAM from Excel } \\
\hline Sales Tax Percentage of Direct Costs & i37 & $\begin{array}{l}\text { Based on the fraction of direct costs made } \\
\text { by materials }\end{array}$ \\
\hline Site Improvement Cost per m2 & $\mathrm{i} 26$ & \\
\hline Solar Field Cost per m2 & $\mathrm{i} 27$ & \\
\hline HTF System Cost per m2 & $\mathrm{i} 28$ & \\
\hline Storage System Cost per kWht & $\mathrm{i} 29$ & \\
\hline Fossil Backup Cost per kWe & $\mathrm{i} 30$ & \\
\hline Power Plant Cost per kWe & $\mathrm{i} 31$ & \\
\hline Contingency & $\mathrm{i} 32$ & \\
\hline Engineer,Procure, Construct & $i 35$ & \\
\hline Project,Land,Management & i36 & \\
\hline Fixed Annual Cost & $\mathrm{i} 41$ & \\
\hline Fixed Cost by Capacity & $\mathrm{i} 42$ & \\
\hline User Variable 2 & $\mathrm{i} 43$ & Annual utility costs in $\$ / y r$ \\
\hline Fossil Fuel Cost & i44 & \\
\hline User Variable 3 & $\mathrm{i} 45$ & Estimated O\&M labor force \\
\hline
\end{tabular}


To access Excel data exchange in SAM, first click Configure Simulations to view the Configure Simulation page:

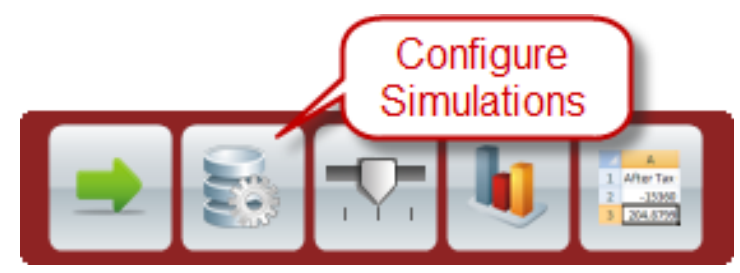

Then click Excel Exchange to display the Excel data exchange options:

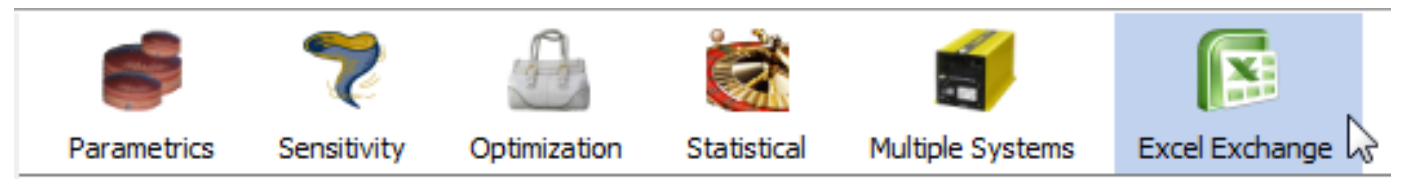

More information on SAM with Excel Exchange can be found in the SAM help files. When retrieving data from Excel via the SAM Excel Exchange, the cells in Excel must not have \$ or \% formatting. Such formatting will cause an error message in SAM. Also, note that after the exchange process, the spreadsheet does not retain the values read in from SAM; in contrast, the SAM case does retain the values captured from the spreadsheet.

\section{References}

1. SolarPACES project lists available at http://www.nrel.gov/csp/solarpaces/

2. National Compensation Survey, U.S. Department of Labor, April 2008, available at http://www.bls.gov/ncs/ncswage2008.htm and http://www.bls.gov/ncs/ocs/compub.htm

3. Kelly, B., "Nexant Parabolic Trough Solar Power Plant Systems Analysis, Task 2: Comparison of Wet and Dry Rankine Cycle Heat Rejection," Subcontract Report, NREL/SR-550-40163, July 2006.

4. Blaney, H.F., "Monthly Consumptive Use of Water by Irrigated Crops and Natural Vegetation," General Assembly of International Union of Geodsy and Geophysics, Toronto, Canada, 1957.

5. Consumptive Use of Water by Major Crops in the Southwestern United States, United States Department of Agriculture, ARS Conservation Research Report 29, May 1982.

6. Kelly, B., and D. Kearney, "Thermal Storage Commercial Plant Design Study for a 2Tank Indirect Molten Salt System," Subcontract Report, NREL/SR-550-40166, July 2006. 
Appendices to NREL TP-550-47605,

Parabolic Trough Reference Plant for Cost Modeling with the Solar Advisor Model; C. Turchi

Appendix A

CSP Parabolic Trough Plant Cost Assessment

WorleyParsons Group

Report under NREL contract KAXL-9-99205-01

September 9, 2009 


\section{CSP Parabolic Trough Plant Cost Assessment}

59002501 - NREL-0-LS-019-0001

9 September 2009

WorleyParsons Group

Americas, Northwest Region

Denver Office

1687 Cole Blvd,

Suite 300,

Golden, CO, 80401, USA

Tel: +1 3039284226

Fax: +1303928 4230 
resources \& energy

NATIONAL RENEWABLE ENERGY LABORATORY

CSP PARABOLIC TROUGH PLANT COST ASSESSMENT

\section{Disclaimer}

This report has been prepared for the National Renewable Energy Laboratory, and is subject to and issued in accordance with the agreement between National Renewable Energy Laboratory and WorleyParsons Services Pty Ltd. WorleyParsons Services Pty Ltd accepts no liability or responsibility whatsoever for it in respect of any use of or reliance upon this report by any third party.

\section{PROJECT 59002501 -}

\begin{tabular}{|c|c|c|c|c|c|c|c|}
\hline REV & DESCRIPTION & ORIG & REVIEW & $\begin{array}{l}\text { WORLEY- } \\
\text { PARSONS } \\
\text { APPROVAL }\end{array}$ & DATE & $\begin{array}{l}\text { CLIENT } \\
\text { APPROVAL }\end{array}$ & DATE \\
\hline \multirow[t]{2}{*}{ A } & DRAFT Issue for Client & & & & $07-24-09$ & $\mathrm{~N} / \mathrm{A}$ & \\
\hline & Review & D.Ross & R.Bowers & G.Aron & & & \\
\hline \multirow[t]{2}{*}{0} & Final Issue & DR & RB & GA & 4-Sep-09 & $\mathrm{N} / \mathrm{A}$ & \\
\hline & & D.Ross & R.Bowers & G.Aron & & & \\
\hline
\end{tabular}


resources \& energy

NATIONAL RENEWABLE ENERGY LABORATORY

CSP PARABOLIC TROUGH PLANT COST ASSESSMENT

\section{TABLE OF CONTENTS}

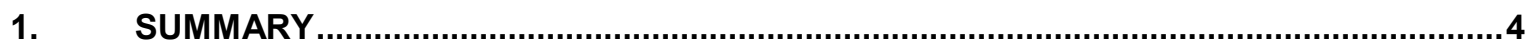

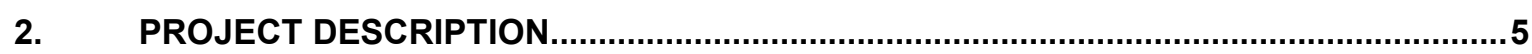

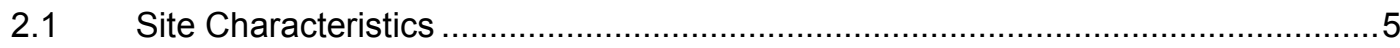

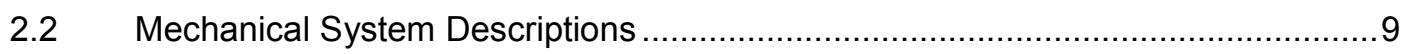

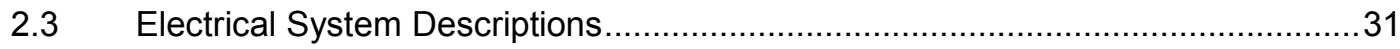

$2.4 \quad$ Instrumentation and Control System Descriptions............................................ 35

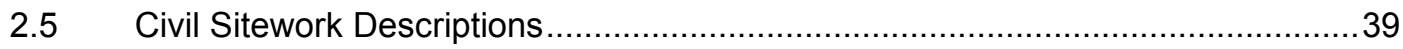

$2.6 \quad$ Structural Support and Foundation Descriptions ............................................... 43

3. COST ESTIMATE BASIS (SUBJECT TO REVISION) .............................................46

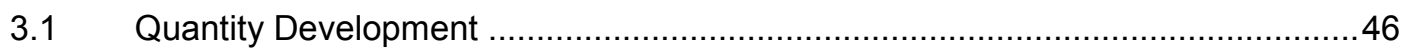

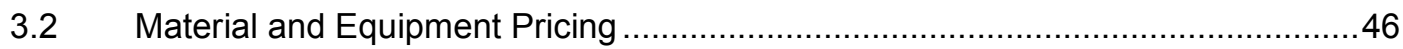

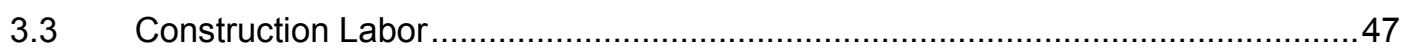

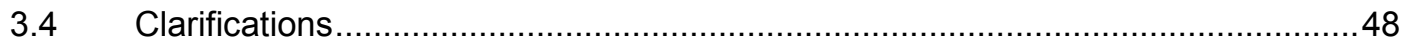

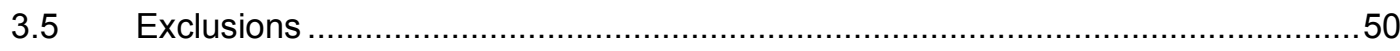

\section{APPENDICES}

Appendix A - Capital Cost Estimate Summary

Appendix B - O\&M Cost Estimate Summary 


\section{LIST OF ACRONYMES}

ASHRAE - American Society of Heating, Refrigeration, and Air-conditioning Engineers

ASME - American Society of Mechanical Engineers

BOP - balance of plant

COC - cycles of concentration

CSP - concentrating solar power

DCS - distributed control system

$\mathrm{DNI}$ - direct normal insolation

EPC - engineer-procure-construct

EPCM - engineer-procure-construction manage

HCE - heat collection element

HTF - heat transfer fluid

$\mathrm{kV}$ - kilovolt

kVA - kilovolt amps

$\mathrm{kW}$ - kilowatt

MVA - megavolt amps

$\mathrm{MWe}$ - megawatt electric

MWth - megawatt thermal

MCC - motor control center

MTO - material take off

NFPA - National Fire Protection Association

NPSHA - net positive suction head available

NREL - National Renewable Energy Laboratory

NSRDB - National Solar Radiation Data Base

P\&ID - process and instrumentation diagram

PLC - programmed logic controller

PDC - power distribution center

SAM - Solar Advisor Model

SCA - Solar Collector Assembly

SCADA - supervisory control and data acquisition

SFC - solar field control

SJAE - steam jet air ejector 
resources \& energy

NATIONAL RENEWABLE ENERGY LABORATORY

CSP PARABOLIC TROUGH PLANT COST ASSESSMENT

SSG - solar steam generator

STG - steam turbine generator

SUNY - State University of New York

TES - thermal energy storage

TMY - typical meteorological year

VFD - variable frequency drive

VSD - variable speed drive

WMO - World Meteorological Organization

\section{LIST OF TABLES AND FIGURES}

Figure 1 - DNI profile plot

Figure 2 - Power block general arrangement sketch

Figure 3 - SCA component diagram

Figure 4 - Loop layout sketch

Figure 5 - Solar field general arrangement sketch

Figure 6 - Empirical sun tracker picture

Figure 7 - Heat collection element picture

Figure 8 - Parabolic mirror picture

Figure 9 - Process flow diagram

Figure 10 - Water balance, peak summer

Figure 11 - Water balance, average annual

Figure 12 - Water balance, average winter

Figure 13 - Thermal storage system sketch

Figure 14 - Mirror wash truck picture

Figure 15 - Electrical one-line diagram, sheet 1

Figure 16 - Electrical one-line diagram, sheet 2

Figure 17 - Asphalt road section detail

Figure 18 - Perimeter road section detail

Figure 19 - Gravel road section detail

Figure 20 - Evaporation pond section detail 
NATIONAL RENEWABLE ENERGY LABORATORY CSP PARABOLIC TROUGH PLANT COST ASSESSMENT

Figure 21 - Salt storage berm section detail

Figure 22 - Salt storage maintenance access drive ramp section detail

Figure 23 - Solar collector foundation pylon, normal

Figure 24 - Solar collector foundation pylon, drive

Table 1- Direct normal insolation 12×24 data set, TMY3

Table 2- Direct normal insolation $12 \times 24$ data set, TMY2

Table 3- Direct normal insolation 12×24 data set, SUNY

Table 4 - Major mechanical equipment list

Table 5 - Heat balance output summary

Table 6 - Major electrical equipment list 
resources \& energy

\author{
NATIONAL RENEWABLE ENERGY LABORATORY \\ CSP PARABOLIC TROUGH PLANT COST ASSESSMENT
}

\title{
1. SUMMARY
}

The purpose of this cost study is to provide the solar power industry with approximate capital and reoccurring costs for a concentrating solar power (CSP) plant using parabolic trough technology. The National Renewable Energy Laboratory (NREL) intends to update the cost output portion of their Solar Advisor Model (SAM) using the results of this study. All costs found by this study are based on a conceptual engineering effort prepared at a high-level, consistent with the intended purpose and confidence of a Level $2(+/-30 \%)$ cost estimate. The base plant design will generate $103 \mathrm{MWe}$ net (118MWe gross) power to the grid at $230 \mathrm{kV}$ using wet cooling and having 6.3 hours of molten salt thermal energy storage. The reference plant requires approximately 1018 acres $\left(4,095,435 \mathrm{~m}^{2}\right)$ of desert land in Daggett California. Site geographic location resource information is limited to solar radiation, ambient conditions, and labor rate profiles. No further site specific information is known, any information necessary for cost estimating (i.e. utility interconnections, water source, infrastructure etc.) is assumed and stated later in the report.

The goal is to capture costs for a "typical" parabolic trough stand-alone plant designed and built in the United States. The Solar Advisor Model calculations will scale, escalate, and adjust the costs of this reference plant given user inputs, and cost indices to arrive at an approximate cost for the userdefined plant design. This study should be viewed as a high-level assessment with the understanding that site specific information along with more research, optimization, detailed engineering and capital cost estimating is required in order to arrive at an optimal CSP parabolic trough plant design that meets the Owner's needs. Owner's costs (i.e. land, permitting, Owner's engineer, risk, loan interest etc.) are excluded from this estimate and will be defined as a user input in SAM.

Total installed capital cost for the 103MWe net reference plant with 6.3 hours of thermal storage in Daggett is $\$ 1.016$ Billion $(\$ 9,861 / \mathrm{kW}$ net) with a $+/-30 \%$ confidence. Operation and maintenance cost is $\$ 14.8 \mathrm{MM}(1.33 \%$ of total installed cost). The plant is designed with an expected life of 30 years with daily startup and shutdown cycling. 


\title{
WorleyParsons
}

resources \& energy

\author{
NATIONAL RENEWABLE ENERGY LABORATORY \\ CSP PARABOLIC TROUGH PLANT COST ASSESSMENT
}

\section{PROJECT DESCRIPTION}

All included subsections provide a brief description of the major cost elements contributing to the total installed cost of the reference plant. Description of the cost estimating process is discussed in a separate section.

\subsection{Site Characteristics}

NREL has selected Daggett California for the reference plant location, as it has been NREL's historic representative location for CSP power plant case studies. No site boundary, resource information, or coordinates were provided. The assumed site acts only as a reference site with the purpose of providing adequate weather, solar, and labor information to estimate the cost of the CSP trough plant. All items affecting cost are identified throughout this report.

\subsubsection{Ambient Conditions}

Local weather information is used for Rankine cycle performance modeling, heat loss calculations, and equipment specifications. Two sources of weather data were used-American Society of Heating, Refrigeration, and Air-Conditioning Engineers (ASHRAE) and Typical Meteorological Year 3 (TMY3) data from Barstow-Daggett Airport station in Daggett California. Heat and mass balance modeling requires ambient conditions such as dry bulb and wet bulb temperatures and atmospheric pressure. Site elevation for Daggett is 1929 feet (589 meters) above sea level which corresponds to an atmospheric pressure of 13.70 psia (0.945 bar) (ASHRAE Handbook - Fundamentals (IP)). Three ambient temperature cases were established to capture the range of site conditions over a typical operating year. All equipment is designed based on the peak summer design case; $108.0^{\circ} \mathrm{F}\left(42.2^{\circ} \mathrm{C}\right)$ dry bulb (ASHRAE $2 \%$ monthly frequency) and $71.3^{\circ} \mathrm{F}\left(21.8^{\circ} \mathrm{C}\right.$ ) wet bulb (average of Jun/Jul/Aug $2 \%$ monthly frequency). The other two off-design cases are average annual and average winter. Average annual temperatures $\left(81.5^{\circ} \mathrm{F} \mathrm{DB}\left[27.5^{\circ} \mathrm{C}\right]\right.$ and $\left.58.1^{\circ} \mathrm{F}\left[14.5^{\circ} \mathrm{C}\right] \mathrm{WB}\right)$ are weighted against the hourly thermal input to the power block for a typical year in order to "best" represent the average operating profile of the plant. For example, midnight temperatures are given zero weight since the plant is offline, whereas noon temperatures are given partial-to-full weight since the plant is at part or full load, respectively. Similarly, average winter temperatures $\left(58.9^{\circ} \mathrm{F}\left[14.9^{\circ} \mathrm{C}\right] \mathrm{DB}\right.$ and $\left.44.4^{\circ} \mathrm{F}\left[6.9^{\circ} \mathrm{C}\right] \mathrm{WB}\right)$ are derived by the same method as average annual except only December, January, and February months are included.

Offline dry bulb temperatures average approximately $60^{\circ} \mathrm{F}\left(15.6^{\circ} \mathrm{C}\right)$. The relatively high dry bulb temperatures in desert locations, which rarely drop below freezing $(<1 \% /$ year $)$, will help to reduce heat loss and hours of freeze protection/circulation operation and therefore increase the amount of solar thermal energy used for generating electricity and/or reduce the amount of overall gas and parasitic power consumption.

Maximum daily wind speed averages range from $2.9 \mathrm{~m} / \mathrm{s}$ in December to $6.7 \mathrm{~m} / \mathrm{s}$ in May (TMY3), while the maximum occurring wind speed in a typical year is $17.5 \mathrm{~m} / \mathrm{s}$. Equipment manufacturers typically require their troughs to be stowed at wind speeds exceeding $\sim 15.6 \mathrm{~m} / \mathrm{s}$ (35 mph). Based on hourly TMY 3 data, this will occur for 10 total hours in a typical year with 8 hours during operation. These infrequent high-wind occurrences support the assumption of not including a wind fence around the solar collector field. However, an in-depth wind study should be done during the project's procurement stage to properly determine the need for wind screening. In addition, wind rose parallel to the trough axis can have a significant effect on receiver heat loss, as opposed to the transverse direction, depending on wind speed and fractional annual duration. Wind rose direction is also critical 


\section{WorleyParsons}

resources \& energy

\section{NATIONAL RENEWABLE ENERGY LABORATORY CSP PARABOLIC TROUGH PLANT COST ASSESSMENT}

in cooling tower orientation. Nevertheless, for purposes of this cost study no wind rose analysis was performed.

\subsubsection{Solar Radiation Resource Selection}

The intensity of available solar radiation, or "fuel", for a concentrating solar power project is among the primary factors driving the power generation capabilities. CSP requires direct normal insolation (DNI) or direct normal irradiation-the component of sunlight that emanates directly from the sun. This direct insolation excludes diffuse and horizontal radiation which is used by photovoltaic solar power. Multiple solar resource data sets were considered and evaluated for modeling solar energy output at the Daggett reference site.

TMY3, TMY2, and State University of New York (SUNY) are among the available data sets for this site. The TMY3 and TMY2 data sets use combined ground measured and satellite-derived data collected from 1991-2005 and 1961-1990, respectively. SUNY data uses a combination of satellitederived data with geographical information system (GIS) data collected from 1998-2005. All data sets use similar algorithms that produce one full year of hourly data to represent a "typical" year among the collected pool. TMY compiles a typical year of solar data using a complete month's dataset closest to the average for the respective month; whereas SUNY uses a complete year's dataset having monthly datasets closest to the average for the respective month. Average hourly DNI per month for each data set is illustrated in Tables 1 to 3 below.

Table 1. TMY3 (1991-2005) direct normal insolation (watt-hr/meter $\left.{ }^{2} / y e a r\right)$ hourly averages per month at Barstow Daggett Airport in Daggett, CA (NSRDB Class I, WMO station 723815).

\begin{tabular}{|c|c|c|c|c|c|c|c|c|c|c|c|c|c|}
\hline Hour of Day & Jan & Feb & Mar & Apr & May & Jun & Jul & Aug & Sep & Oct & Nov & Dec & Average \\
\hline 0.5 & 0 & 0 & 0 & 0 & 0 & 0 & 0 & 0 & 0 & 0 & 0 & 0 & 0 \\
\hline 1.5 & 0 & 0 & 0 & 0 & 0 & 0 & 0 & 0 & 0 & 0 & 0 & 0 & 0 \\
\hline 2.5 & 0 & 0 & 0 & 0 & 0 & 0 & 0 & 0 & 0 & 0 & 0 & 0 & 0 \\
\hline 3.5 & 0 & 0 & 0 & 0 & 0 & 0 & 0 & 0 & 0 & 0 & 0 & 0 & 0 \\
\hline 4.5 & 0 & 0 & 0 & 0 & 0 & 41 & 15 & 0 & 0 & 0 & 0 & 0 & 5 \\
\hline 5.5 & 0 & 0 & 12 & 147 & 341 & 409 & 298 & 182 & 68 & 8 & 0 & 0 & 122 \\
\hline 6.5 & 10 & 44 & 248 & 448 & 585 & 653 & 562 & 569 & 484 & 315 & 119 & 0 & 336 \\
\hline 7.5 & 274 & 443 & 525 & 601 & 687 & 773 & 695 & 755 & 677 & 593 & 496 & 397 & 576 \\
\hline 8.5 & 440 & 565 & 627 & 674 & 742 & 833 & 752 & 840 & 795 & 681 & 673 & 526 & 679 \\
\hline 9.5 & 548 & 610 & 695 & 733 & 757 & 873 & 801 & 871 & 848 & 814 & 739 & 576 & 739 \\
\hline 10.5 & 621 & 635 & 712 & 694 & 783 & 875 & 799 & 910 & 830 & 813 & 779 & 608 & 755 \\
\hline 11.5 & 635 & 676 & 712 & 764 & 791 & 873 & 816 & 899 & 870 & 792 & 775 & 693 & 775 \\
\hline 12.5 & 654 & 684 & 708 & 782 & 795 & 825 & 796 & 918 & 884 & 754 & 732 & 702 & 770 \\
\hline 13.5 & 605 & 713 & 667 & 757 & 758 & 809 & 785 & 880 & 844 & 732 & 668 & 644 & 739 \\
\hline 14.5 & 522 & 562 & 645 & 684 & 729 & 755 & 768 & 792 & 781 & 725 & 567 & 551 & 673 \\
\hline 15.5 & 440 & 609 & 514 & 622 & 634 & 702 & 701 & 691 & 737 & 591 & 461 & 480 & 599 \\
\hline 16.5 & 191 & 438 & 393 & 559 & 569 & 638 & 675 & 571 & 586 & 315 & 107 & 121 & 430 \\
\hline 17.5 & 3 & 54 & 171 & 173 & 445 & 537 & 517 & 379 & 208 & 9 & 0 & 0 & 208 \\
\hline 18.5 & 0 & 0 & 1 & 2 & 140 & 222 & 204 & 52 & 0 & 0 & 0 & 0 & 52 \\
\hline 19.5 & 0 & 0 & 0 & 0 & 0 & 0 & 0 & 0 & 0 & 0 & 0 & 0 & 0 \\
\hline 20.5 & 0 & 0 & 0 & 0 & 0 & 0 & 0 & 0 & 0 & 0 & 0 & 0 & 0 \\
\hline 21.5 & 0 & 0 & 0 & 0 & 0 & 0 & 0 & 0 & 0 & 0 & 0 & 0 & 0 \\
\hline 22.5 & 0 & 0 & 0 & 0 & 0 & 0 & 0 & 0 & 0 & 0 & 0 & 0 & 0 \\
\hline 23.5 & 0 & 0 & 0 & 0 & 0 & 0 & 0 & 0 & 0 & 0 & 0 & 0 & 0 \\
\hline TOTAL W-hr/m²/day & 4943 & 6033 & 6630 & 7640 & 8756 & 9818 & 9184 & 9309 & 8612 & 7142 & 6116 & 5298 & 7457 \\
\hline \# of Days/Month & 31 & 28 & 31 & 30 & 31 & 30 & 31 & 31 & 30 & 31 & 30 & 31 & 30.4 \\
\hline TOTAL W-hr $/ \mathrm{m}^{2} /$ month & 153,233 & 168,924 & 205,530 & 229,200 & 271,436 & 294,540 & 284,704 & 288,579 & 258,360 & 221,402 & 183,480 & 164,238 & 226,969 \\
\hline
\end{tabular}




\section{WorleyParsons}

resources \& energy

NATIONAL RENEWABLE ENERGY LABORATORY CSP PARABOLIC TROUGH PLANT COST ASSESSMENT

Table 2. TMY2 (1961-1990) direct normal insolation (watt-hr/meter $\left.{ }^{2} / y e a r\right)$ hourly averages per month at Barstow Daggett Airport in Daggett, CA (NSRDB Class A, WMO station 723815).

\begin{tabular}{|c|c|c|c|c|c|c|c|c|c|c|c|c|c|}
\hline Hour of Day & Jan & Feb & Mar & Apr & May & Jun & Jul & Aug & Sep & Oct & Nov & $\overline{D e c}$ & Average \\
\hline 0.5 & 0 & 0 & 0 & 0 & 0 & 0 & 0 & 0 & 0 & 0 & 0 & 0 & 0 \\
\hline 1.5 & 0 & 0 & 0 & 0 & 0 & 0 & 0 & 0 & 0 & 0 & 0 & 0 & 0 \\
\hline 2.5 & 0 & 0 & 0 & 0 & 0 & 0 & 0 & 0 & 0 & 0 & 0 & 0 & 0 \\
\hline 3.5 & 0 & 0 & 0 & 0 & 0 & 0 & 0 & 0 & 0 & 0 & 0 & 0 & 0 \\
\hline 4.5 & 0 & 0 & 0 & 0 & 15 & 41 & 13 & 0 & 0 & 0 & 0 & 0 & 6 \\
\hline 5.5 & 0 & 0 & 12 & 155 & 297 & 409 & 297 & 179 & 81 & 9 & 0 & 0 & 120 \\
\hline 6.5 & 3 & 71 & 273 & 511 & 550 & 642 & 543 & 505 & 487 & 325 & 119 & 24 & 338 \\
\hline 7.5 & 264 & 387 & 557 & 681 & 676 & 750 & 667 & 669 & 684 & 581 & 496 & 348 & 563 \\
\hline 8.5 & 518 & 545 & 692 & 798 & 736 & 812 & 732 & 746 & 785 & 704 & 673 & 551 & 691 \\
\hline 9.5 & 655 & 629 & 737 & 847 & 770 & 837 & 782 & 809 & 848 & 763 & 739 & 650 & 756 \\
\hline 10.5 & 692 & 665 & 780 & 871 & 806 & 854 & 798 & 807 & 850 & 807 & 779 & 690 & 783 \\
\hline 11.5 & 723 & 684 & 768 & 890 & 829 & 859 & 807 & 829 & 852 & 777 & 775 & 683 & 790 \\
\hline 12.5 & 724 & 668 & 769 & 846 & 823 & 826 & 821 & 799 & 820 & 753 & 732 & 681 & 772 \\
\hline 13.5 & 717 & 677 & 744 & 834 & 802 & 842 & 802 & 785 & 777 & 757 & 668 & 661 & 755 \\
\hline 14.5 & 653 & 646 & 701 & 814 & 756 & 777 & 797 & 743 & 734 & 699 & 567 & 568 & 705 \\
\hline 15.5 & 523 & 581 & 624 & 722 & 717 & 748 & 749 & 663 & 604 & 596 & 461 & 409 & 617 \\
\hline 16.5 & 240 & 426 & 511 & 653 & 643 & 670 & 659 & 570 & 518 & 343 & 107 & $\begin{array}{l}409 \\
109\end{array}$ & 454 \\
\hline 17.5 & 3 & 84 & 205 & 429 & 457 & 528 & 519 & 403 & 238 & 19 & 0 & 0 & 240 \\
\hline 18.5 & 0 & 0 & 1 & 37 & 108 & 217 & 197 & 74 & 2 & 0 & 0 & 0 & 53 \\
\hline 19.5 & 0 & 0 & 0 & 0 & 0 & 0 & 0 & 0 & 0 & 0 & 0 & 0 & 0 \\
\hline 20.5 & 0 & 0 & 0 & 0 & 0 & 0 & 0 & 0 & 0 & 0 & 0 & 0 & 0 \\
\hline 21.5 & 0 & 0 & 0 & 0 & 0 & 0 & 0 & 0 & 0 & 0 & 0 & 0 & 0 \\
\hline 22.5 & 0 & 0 & 0 & 0 & 0 & 0 & 0 & 0 & 0 & 0 & 0 & 0 & 0 \\
\hline 23.5 & 0 & 0 & 0 & 0 & 0 & 0 & 0 & 0 & 0 & 0 & 0 & 0 & 0 \\
\hline TOTAL W-hr/m²/day & 5716 & 6063 & 7374 & 9089 & 8984 & 9812 & 9184 & 8582 & 8280 & 7132 & 6116 & 5375 & 7642 \\
\hline \# of Days/Month & 31 & 28 & 31 & 30 & 31 & 30 & 31 & 31 & 30 & 31 & 30 & 31 & 30.4 \\
\hline TOTAL W-hr $/ \mathrm{m}^{2} /$ month & 177,193 & 169,753 & 228,583 & 272,661 & 278,517 & 294,374 & 284,708 & 266,037 & 248,405 & 221,104 & 183,478 & 166,612 & 232.619 \\
\hline
\end{tabular}

Table 3. SUNY (1998-2005) direct normal insolation (watt-hr/meter ${ }^{2} /$ year) hourly averages per month for $10 \mathrm{~km}$ grid over undisturbed area in Daggett, CA (radwx_116653495_9805.tm2).

\begin{tabular}{|c|c|c|c|c|c|c|c|c|c|c|c|c|c|}
\hline Hour of Day & Jan & Feb & Mar & Apr & May & Jun & Jul & Aug & Sep & Oct & Nov & Dec & Average \\
\hline 0.5 & 0 & 0 & 0 & 0 & 0 & 0 & 0 & 0 & 0 & 0 & 0 & 0 & 0 \\
\hline 1.5 & 0 & 0 & 0 & 0 & 0 & 0 & 0 & 0 & 0 & 0 & 0 & 0 & 0 \\
\hline 2.5 & 0 & 0 & 0 & 0 & 0 & 0 & 0 & 0 & 0 & 0 & 0 & 0 & 0 \\
\hline 3.5 & 0 & 0 & 0 & 0 & 0 & 0 & 0 & 0 & 0 & 0 & 0 & 0 & 0 \\
\hline 4.5 & 0 & 0 & 0 & 0 & 0 & 0 & 0 & 0 & 0 & 0 & 0 & 0 & 0 \\
\hline 5.5 & 0 & 0 & 0 & 154 & 367 & 418 & 346 & 217 & 53 & 0 & 0 & 0 & 130 \\
\hline 6.5 & 0 & 38 & 280 & 476 & 564 & 669 & 619 & 542 & 504 & 351 & 120 & 0 & 347 \\
\hline 7.5 & 309 & 381 & 498 & 645 & 670 & 763 & 690 & 691 & 697 & 550 & 480 & 382 & 563 \\
\hline 8.5 & 517 & 507 & 633 & 693 & 793 & 820 & 737 & 777 & 791 & 706 & 641 & 561 & 681 \\
\hline 9.5 & 619 & 617 & 701 & 773 & 783 & 833 & 743 & 812 & 782 & 738 & 723 & 687 & 734 \\
\hline 10.5 & 644 & 606 & 687 & 779 & 814 & 866 & 759 & 783 & 829 & 823 & 736 & 664 & 749 \\
\hline 11.5 & 678 & 631 & 715 & 737 & 823 & 862 & 743 & 786 & 815 & 784 & 738 & 707 & 752 \\
\hline 12.5 & 705 & 627 & 673 & 717 & 818 & 861 & 744 & 758 & 817 & 766 & 715 & 705 & 742 \\
\hline 13.5 & 708 & 660 & 687 & 684 & 793 & 826 & 736 & 693 & 783 & 802 & 730 & 632 & 728 \\
\hline 14.5 & 618 & 549 & 675 & 656 & 778 & 762 & 732 & 707 & 772 & 677 & 643 & 606 & 681 \\
\hline 15.5 & 577 & 517 & 678 & 631 & 719 & 771 & 689 & 615 & 687 & 626 & 588 & 537 & 636 \\
\hline 16.5 & 131 & 412 & 592 & 560 & 567 & 671 & 635 & 527 & 608 & 250 & 168 & 130 & 438 \\
\hline 17.5 & 0 & 44 & 193 & 190 & 444 & 573 & 547 & 364 & 143 & 0 & 0 & 0 & 208 \\
\hline 18.5 & 0 & 0 & 0 & 0 & 140 & 114 & 152 & 57 & 0 & 0 & 0 & 0 & 39 \\
\hline 19.5 & 0 & 0 & 0 & 0 & 0 & 0 & 0 & 0 & 0 & 0 & 0 & 0 & 0 \\
\hline 20.5 & 0 & 0 & 0 & 0 & 0 & 0 & 0 & 0 & 0 & 0 & 0 & 0 & 0 \\
\hline 21.5 & 0 & 0 & 0 & 0 & 0 & 0 & 0 & 0 & 0 & 0 & 0 & 0 & 0 \\
\hline 22.5 & 0 & 0 & 0 & 0 & 0 & 0 & 0 & 0 & 0 & 0 & 0 & 0 & 0 \\
\hline 23.5 & 0 & 0 & 0 & 0 & 0 & 0 & 0 & 0 & 0 & 0 & 0 & 0 & 0 \\
\hline TOTAL W-hr/m²/day & 5506 & 5587 & 7014 & 7695 & 9073 & 9810 & 8871 & 8329 & 8280 & 7073 & 6281 & 5612 & 7428 \\
\hline \# of Days/Month & 31 & 28 & 31 & 30 & 31 & 30 & 31 & 31 & 30 & 31 & 30 & 31 & 30.4 \\
\hline TOTAL W-hr $/ \mathrm{m}^{2} /$ month & 170,679 & 156,449 & 217,441 & 230,836 & 281,272 & 294,296 & 275,003 & 258,193 & 248,386 & 219,270 & 188,429 & 173,957 & 226,184 \\
\hline
\end{tabular}

TMY3 data was selected as the representative dataset for the Daggett site. Although SUNY records data within a $10 \mathrm{~km}$ grid over the site, it will not be used primarily due to the uncertainty of the TMY3 data being categorized as Class 1 , which is the lowest uncertainty among all solar radiation data sources. National Solar Radiation Data Base (NSRDB) Class I data sets have a complete period of record for all parameters from 1991 to 2005 with an uncertainty of $\pm 10-15 \%$. SUNY data has estimated uncertainties that range up to $\pm 20 \%$ (NREL Solar Resources Workshop "NSRDB $10 \mathrm{~km}$ Gridded Hourly Solar Database" Oct. 2008 presentation). Furthermore, TMY3 gathers data from a larger pool than SUNY (14 years vs. 7 years) and therefore may be more representative of the site's radiation profile for a typical year. The considered TMY2 data for Daggett (same WMO station as TMY3 for Barstow-Daggett Airport) is highly ranked Class A data (having a minimum of 15 candidate months without more than 2 consecutive hours of missing data). Nevertheless, TMY2 data was collected nearly 20 years ago and could possibly misrepresent the recent climate changes, thus 
resources \& energy

\section{NATIONAL RENEWABLE ENERGY LABORATORY CSP PARABOLIC TROUGH PLANT COST ASSESSMENT}

adding to the uncertainty of the data.

Annual DNI averages shown in the figures above illustrate the close similarity between the three available datasets; TMY3 rests between the two other data sources. In summary, TMY3 data for the Daggett site has a few slight advantages over the other considered solar resources. Specifically, TMY3 data has the least error uncertainty, has the most recent and largest combined data pool, and is within $<3 \%$ of SUNY and TMY2 data.

Design point direct normal insolation for solar field sizing was selected at 1,000 watts $/ \mathrm{m}^{2}$ (at zero incident angle), typical of most Southwestern United States CSP sites and further supported by Chapter 6 in "Recent Advances in Parabolic Trough Solar Power Plant Technology" (Kearney \& Associates and NREL,). For annual generation the occurrence of design point DNI is an important factor. Although this study does not estimate annual performance, it's important to note that Daggett SUNY data shows 3 hours of 1000 watts $/ \mathrm{m}^{2}$ or greater over the 8760 hours in a year; whereas TMY 3 has 37 hours.

Without storage, the plant is designed to have a solar multiple of 1.25 (i.e. $25 \%$ larger than needed for full plant output at 1000 watts $/ \mathrm{m} 2$ ). The purpose of this solar multiple is to provide more mirror area to account for radiation losses when the sun is at lower latitude and when radiation is less than design (mornings \& afternoons).

Figure 1 below compares peak day, peak month average, and minimum month average DNI by hour for the Daggett site. Sun angle and shortened days are the main contributors to the low winter DNI. Hence a solar multiple (defined later) is applied to the solar field size to account for the lower radiation seen in shoulder and winter months as well as the off-design DNI in the early and later hours of the day. Keep in mind these trends are not directly related to plant output; mainly due to the impact of thermal storage and increased steam cycle efficiencies where lower ambient temperatures are coincident with high DNI. 
resources \& energy

NATIONAL RENEWABLE ENERGY LABORATORY

CSP PARABOLIC TROUGH PLANT COST ASSESSMENT

Figure 1. Peak day, average peak month, and average minimum month DNI profiles using TMY3 data for Daggett California.

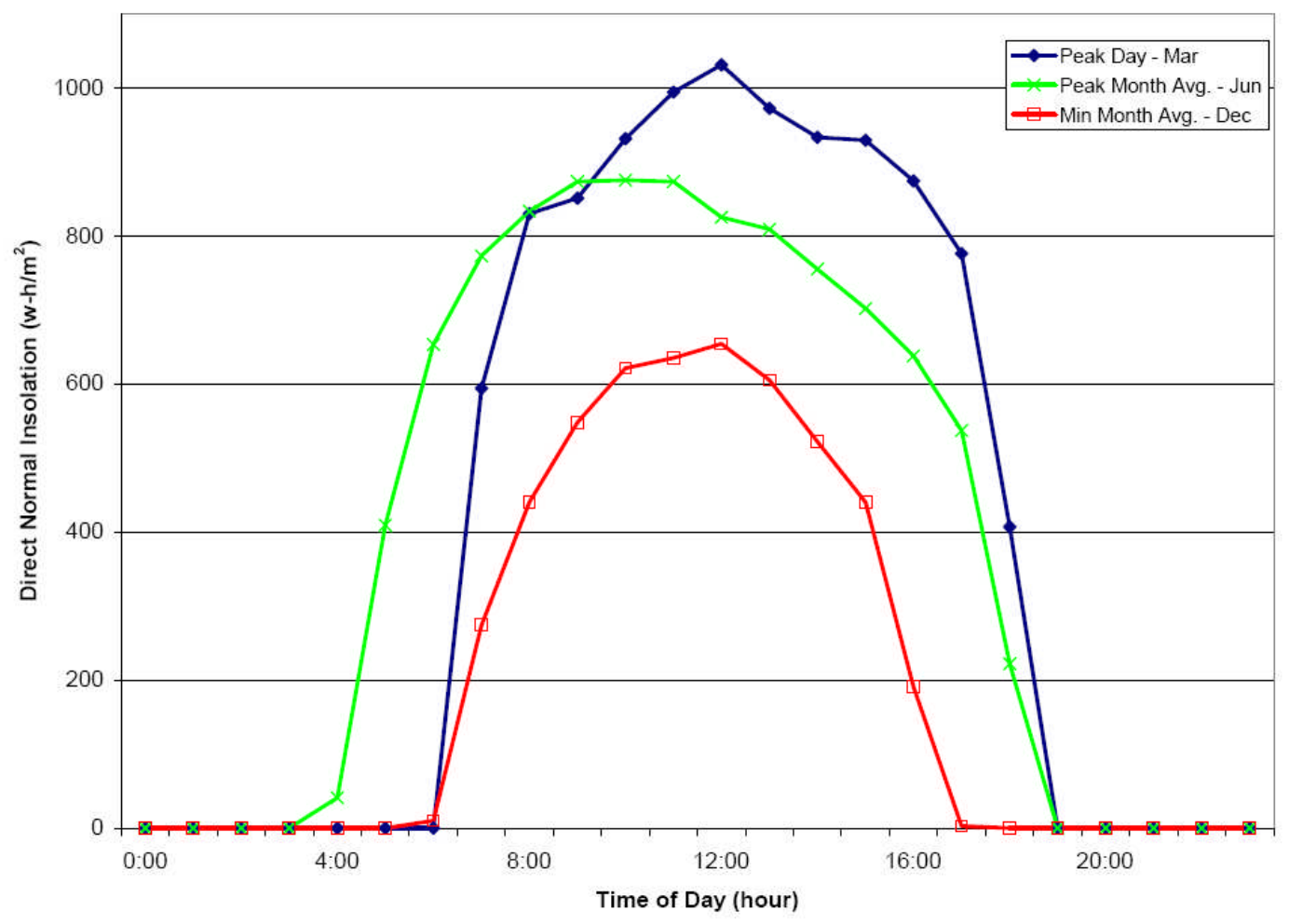

\subsection{Mechanical System Descriptions}

The stand-alone parabolic trough plant with thermal storage is made up of several interconnecting systems all working together to provide electricity to the power grid. The following systems make up the thermal cycle for the reference plant:

- Solar thermal collection field

- Heat transfer fluid system

- Rankine cycle

- Thermal energy storage

- Balance of plant

A brief description of each primary system and its sub-systems will be discussed throughout this section. Below is a list of the major mechanical equipment which makes up the reference plant design. Bulk mechanical materials such as valves, piping, fasteners etc. are not listed at this design level, but are included in the cost estimate. Further supporting sketches, flow diagrams, lists, tables, and figures are provided to better illustrate the design basis of the cost estimate. Other significant cost items in a CSP plant include civil, structural, electrical, and controls. These are discussed later in the report. 
resources \& energy

NATIONAL RENEWABLE ENERGY LABORATORY CSP PARABOLIC TROUGH PLANT COST ASSESSMENT

Table 4. Major mechanical equipment list for Daggett reference plant.

\begin{tabular}{|c|c|}
\hline EQUIPMENT NAME & QTY \\
\hline \multicolumn{2}{|l|}{ SOLAR COLLECTOR ASSEMBLIES } \\
\hline Solar Collector Mirrors & 405,888 \\
\hline Solar Collector Receiver Tubes (Heat Collection Elements) & 43,488 \\
\hline Solar Collector Assemblies/Drives & 1208 \\
\hline \multicolumn{2}{|l|}{ THERMAL ENERGY STORAGE (by EPC Vendor) } \\
\hline Cold Salt Tanks (incl. foundations) & 2 \\
\hline Cold Tank Immersion Heater & 4 \\
\hline Hot Salt Tanks (incl. foundations) & 2 \\
\hline Hot Tank Immersion Heater & 4 \\
\hline Hot Salt Pumps & $3 \times 50 \% / \operatorname{tank}$ \\
\hline Cold Salt Pumps & $3 \times 50 \% /$ tank \\
\hline Salt to HTF Heat Exchangers & 6 \\
\hline Bulk Salt Storage & $62 \mathrm{kMT}$ \\
\hline Nitrogen Storage and Vaporization System & Lot \\
\hline \multicolumn{2}{|l|}{ STEAM TURBINE \& AUXILIARIES } \\
\hline Steam Turbine & 1 \\
\hline Generator (w/ steam turbine supply) & 1 \\
\hline Gland Steam Condenser (w/ steam turbine supply) & 1 \\
\hline Lube Oil and Hydraulic Oil Skids (w/ steam turbine supply) & 1 \\
\hline Cooling Tower & 1 \\
\hline Steam Surface Condenser & 1 \\
\hline Steam Jet Air Ejector (SJAE) (Holding and Hogging ejectors) & 1 \\
\hline Deaerator/Storage Tank (open feedwater heater \#4) & 1 \\
\hline Closed Feedwater Heaters ( 3 LP and $1 \mathrm{HP}$ ) & 4 \\
\hline \multicolumn{2}{|l|}{ HEAT EXCHANGERS } \\
\hline Economizer (preheater) & $1 \times 100 \%$ \\
\hline EQUIPMENT NAME & QTY \\
\hline Evaporator (steam generator) & $2 \times 50 \%$ \\
\hline Reheater & $2 \times 50 \%$ \\
\hline Superheater & $1 \times 100 \%$ \\
\hline Closed Cooling Water Heat Exchangers & $2 \times 100 \%$ \\
\hline HTF Freeze Protection Condenser & 1 \\
\hline \multicolumn{2}{|l|}{ PUMPS } \\
\hline HTF Main Circulation & $4 \times 33 \%$ \\
\hline HTF Freeze Protection Circulation & $1 \times 100 \%$ \\
\hline HTF Overflow Tank Transfer (to Exp Tank) & $2 \times 100 \%$ \\
\hline Feedwater & $2 \times 100 \%$ \\
\hline Feedwater Drip Pump & $2 \times 100 \%$ \\
\hline Circulating Water & $2 \times 100 \%$ \\
\hline Aux Cooling Water (backup/startup) & $1 \times 100 \%$ \\
\hline Closed Cooling Water & $2 \times 100 \%$ \\
\hline Boiler Blowdown Sump (from sump to cooling tower basin) & $2 \times 100 \%$ \\
\hline Cooling Tower Blowdown Booster (circ water header to evap ponds) & $2 \times 100 \%$ \\
\hline
\end{tabular}


resources \& energy

NATIONAL RENEWABLE ENERGY LABORATORY CSP PARABOLIC TROUGH PLANT COST ASSESSMENT

\begin{tabular}{|c|c|}
\hline Condensate Forwarding & $2 \times 100 \%$ \\
\hline Demineralized Water Forwarding (cycle makeup) & $2 \times 100 \%$ \\
\hline Demineralized Water Startup/Cycle Makeup Pump & $1 \times 100 \%$ \\
\hline Demineralizer Feed Pumps & $2 \times 100 \%$ \\
\hline Potable Water & $2 \times 100 \%$ \\
\hline Oil-Water Separator Effluent Forwarding & $2 \times 100 \%$ \\
\hline Well Water Forwarding & $3 \times 50 \%$ \\
\hline Service Water (from Raw/Fire water Tank) & $2 \times 100 \%$ \\
\hline Firewater Pump (Electric Driven, see emission-generating equipment below) & $1 \times 100 \%$ \\
\hline Firewater Jockey (Pressure Maintenance) & $1 \times 100 \%$ \\
\hline \multicolumn{2}{|l|}{ TANKS } \\
\hline Demineralized Water Storage (Field Erected) & $2 \times 100 \%$ \\
\hline Raw/Fire/CT Makeup Water Storage (Field Erected) & $1 \times 100 \%$ \\
\hline Potable Water Storage (Shop Fab) & $1 \times 100 \%$ \\
\hline Blowdown/Flash Tank (Shop Fab) & $1 \times 100 \%$ \\
\hline Turbine Area Flash Tank (Shop Fab) & $1 \times 100 \%$ \\
\hline Closed Cooling Water Expansion Tank (Shop Fab) & $1 \times 100 \%$ \\
\hline HTF Expansion \& Overflow Tanks (Shop Fab) & $\begin{array}{l}1 \text { Expansion } \\
6 \text { Overflow }\end{array}$ \\
\hline \multicolumn{2}{|l|}{ HTF ULLAGE SYSTEM } \\
\hline Ullage Vessel Return Pump & $1 \times 100 \%$ \\
\hline Ullage Recirculating Pump & $1 \times 100 \%$ \\
\hline Ullage Recirculating Air-Cooler & 1 \\
\hline Ullage Air-Cooled Condenser & 1 \\
\hline Ullage Drain Vessel Intercooler & 1 \\
\hline Ullage Vessel & 1 \\
\hline Ullage Waste Storage Tank (Hot) & 1 \\
\hline Ullage Waste Storage Tank (Cold) & 1 \\
\hline Ullage Flash Tank & 1 \\
\hline Ullage Drain Vessel & 1 \\
\hline \multicolumn{2}{|l|}{ EMISSION GENERATING EQUIPMENT } \\
\hline Gas-Fired Auxiliary Packaged Boiler (turbine seals/warm-up, SJAE) & 1 \\
\hline Emergency Diesel Generator & 1 \\
\hline Diesel-Driven Firewater Pump & $1 \times 100 \%$ \\
\hline \multicolumn{2}{|l|}{ OTHER EQUIPMENT } \\
\hline Oil-Free Air Compressor, Dryer, Receiver Tank & $2 \times 100 \%$ \\
\hline Bulk Nitrogen Storage \& Vaporizer & 1 \\
\hline Diesel Fuel Tank \& Pump System (On-site Mirror Wash Trucks) & 1 \\
\hline Mirror Wash Truck Demineralized Water Fill Station & 1 \\
\hline Oil/Water Separator (not for HTF/water separation) & 1 \\
\hline Sample Panel & 1 \\
\hline Cycle Chemical Feed & Lot \\
\hline Cooling Tower Chemical Feed/Storage System & Lot \\
\hline Demineralized Water Treatment System & Lot \\
\hline
\end{tabular}


Figure 2 below represents a conceptual layout of the major equipment within the power block for the reference plant. Equipment sizes are based on vendor information, past project archives, or engineering judgment/estimates. Equipment arrangement aims to provide a functional layout which meets plant operation and maintenance needs. 


\title{
WiI WorleyParsons
}

\author{
resources \& energy
}

NATIONAL RENEWABLE ENERGY LABORATORY

CSP PARABOLIC TROUGH PLANT COST ASSESSMENT

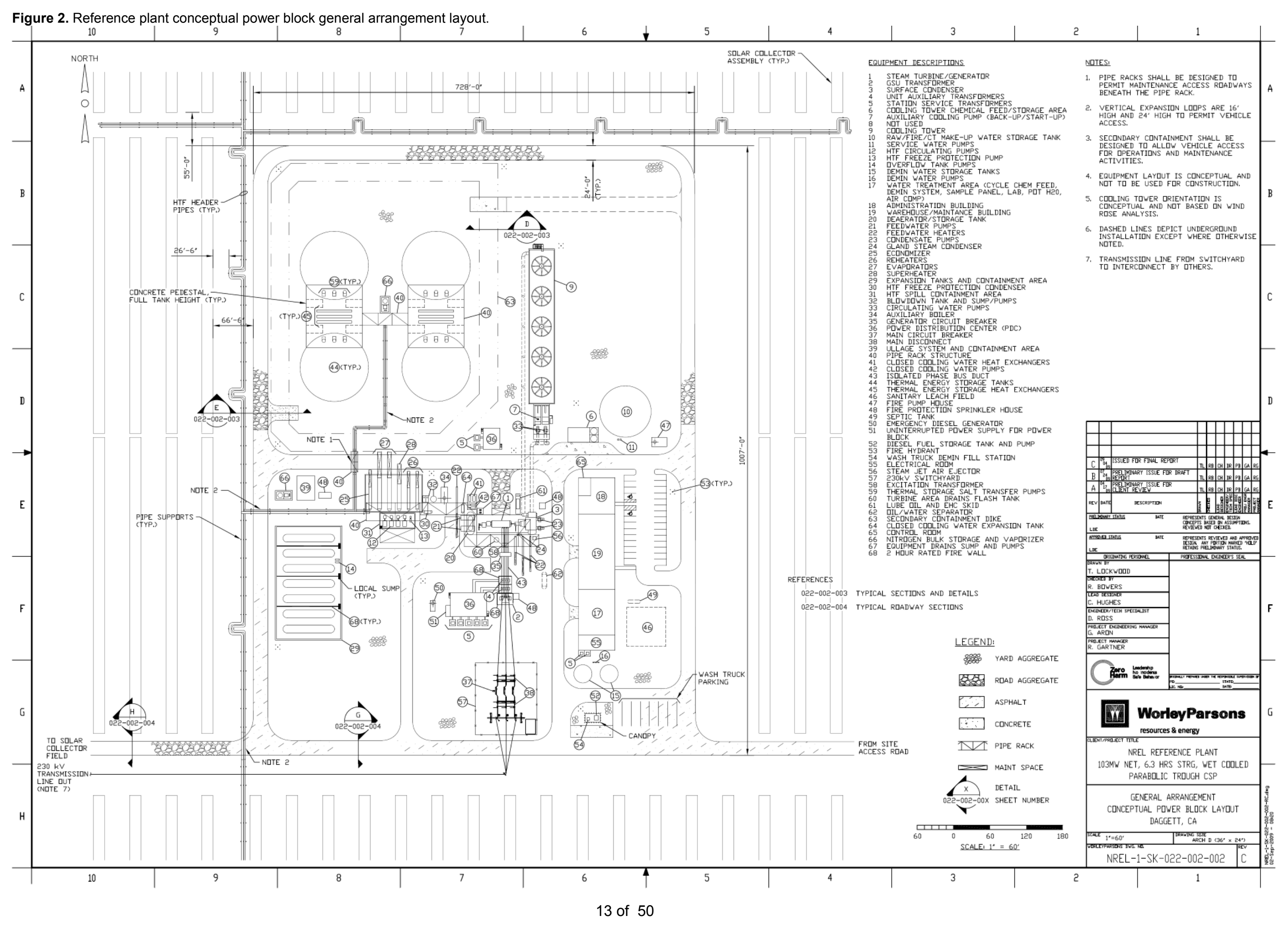




\subsubsection{Solar Thermal Collection Field}

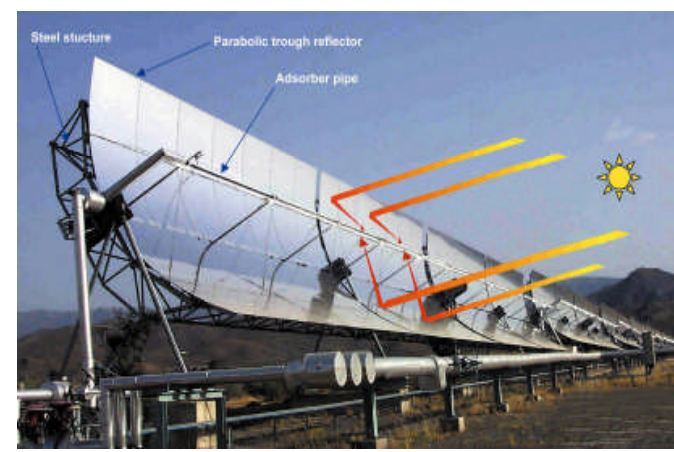

Figure 3. Solar collector assembly diagram showing direct radiation path.

As illustrated in figure 5 below, the solar field area will also encompass permanent HTF piping, power and instrument cable, asphalt access roads and perimeter gravel roads, security fencing, storm water detention pond, waste water evaporation ponds, land farm / bioremediation area, switchyard, water and natural gas supply lines and the utility's transmission lines. Solar field temporary facilities include a fabric tent solar collector assembly facility, and a construction lay down area with trailers and parking for solar field and power block construction.

The Daggett reference plant consists of 1208 solar collector assemblies (SCA), each 150 meters long having $817.5 \mathrm{~m}^{2}$ of effective aperture mirror area. Combined, the solar field has $987,540 \mathrm{~m}^{2}$ of effective aperture mirror area which can provide $\sim 250 \mathrm{MW}$ th to the thermal storage system and $407 \mathrm{MW}$ th to the power block. Four (4) SCAs make up a single circuit of "cold" $\left(\sim 560^{\circ} \mathrm{F} / 293.3^{\circ} \mathrm{C}\right)$ to "hot" $\left(\sim 740^{\circ} \mathrm{F} /\right.$ $\left.393.3^{\circ} \mathrm{C}\right) \mathrm{HTF}$ where two SCAs are aligned end-to-end in a common row and connect to another row of two SCAs making the loop (Figure 4).
Parabolic trough technology concentrates DNI, using single-axis sun tracking, onto a heat collection element (HCE) located at the focal line of the parabolic surface (Figure 3). A high temperature heat transfer fluid (HTF) such as synthetic oil with a relatively low freezing point, low vapor pressure, and the capability to retain heat absorbs the thermal energy in the HCE as it flows through the receiver tubes. Heat collected in the HCE is transported to the solar power block where a series of shell-and-tube heat exchangers, collectively the solar steam generator (SSG) boils and superheats incoming feedwater.

"Cold" HTF is pumped through the "cold" header pipes from the power block to the first SCA in each loop. "Hot" HTF is returned to the "hot" header pipes and transferred back to the power block SSG. 


\title{
Wh WorleyParsons
}

\author{
resources \& energy
}

NATIONAL RENEWABLE ENERGY LABORATORY

CSP PARABOLIC TROUGH PLANT COST ASSESSMENT

Figure 5. Reference plant conceptual solar field general arrangement layout.

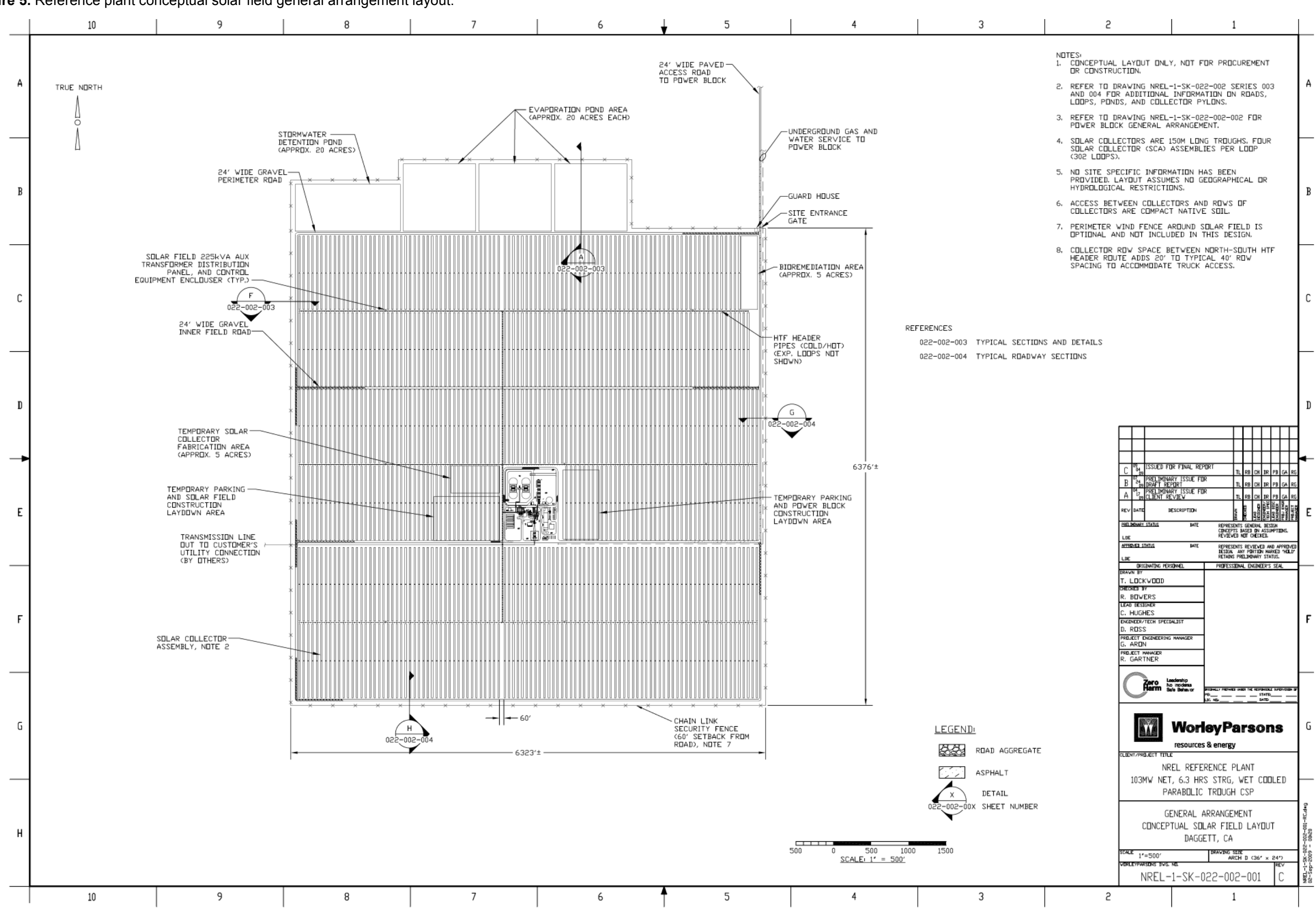




\section{WorleyParsons}

resources \& energy

\section{NATIONAL RENEWABLE ENERGY LABORATORY CSP PARABOLIC TROUGH PLANT COST ASSESSMENT}

\section{SOLAR Collector ASSEMBY}

An SCA is primarily composed of parabolic mirror facets with backing plates, heat collection elements with supports, a hydraulic actuator drive, and a sun tracking sensor; all supported by a metal support structure. The interconnecting piping system (except ball joints) and collector foundations are typically not considered part of the SCA manufacturer's supply; but are engineered and constructed by the general contractor.

The collector field is made up of multiple rows of SCAs, which are the basic, modular building blocks of the solar energy collection system. The solar collectors will rotate slowly east to west during each day to track the sun's movement and to keep the sun's rays focused on the absorber tube. This reference plant uses hydraulic actuators which are driven by a $\sim 1 \mathrm{hp}(0.746 \mathrm{~kW})$ electric pump motor. These two-speed drives intermittently track the sun (low speed) and continuously stow the SCAs (high speed) during the appropriate operation mode.

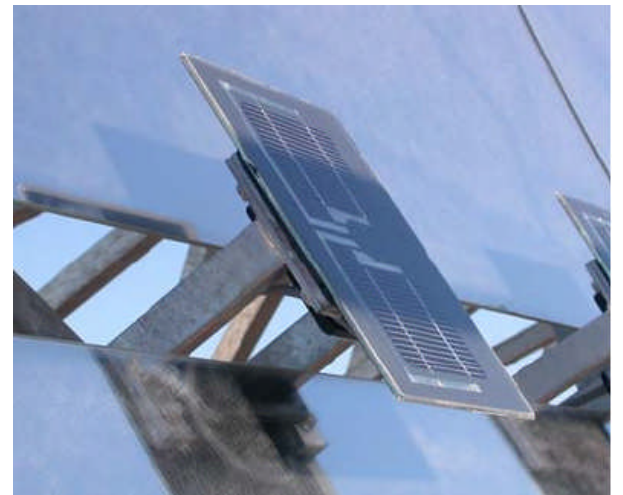

Figure 6. Empirical sun tracker.
Each SCA will track the sun via a logic controller located in the collector drive housing. The logic is preprogrammed using a GPS system to orient the SCA at the calculated sun position. Additionally included in this reference plant design is an empirical sun tracker that directly watches the sun's path by measuring a voltage differential created by a shadow casted on a flat plate photovoltaic cell which sits centrally behind the HCE just in front of the mirror (Figure 6). This empirically based tracker will typically orient the SCA during operation while the logic tracker will be used for deploy and stow positioning, or when clouds obscure the sensor.

\section{heat Collection Element}

The heat collection element absorbs heat into the HTF. This element consists of a coated stainless steel tube surrounded by a glass tube insulator holding a vacuum between the pipe and the glass, also known as evacuated glass (Figure 7). The coating on the steel tube decreases reflectivity and increases its heat absorption capabilities. The outer glass cylinder has anti-reflective coating on the inner and outer surfaces to reduce reflective losses, increasing the transmission of solar energy. Metallic substances called "getters" are installed in the annular space to absorb hydrogen and other vacuum depleting gases.

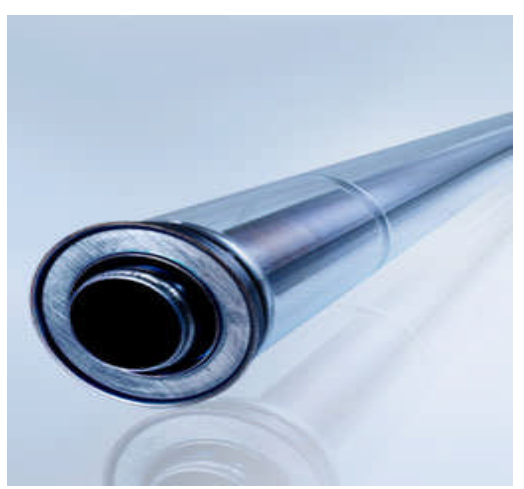

Figure 7. Heat collection element

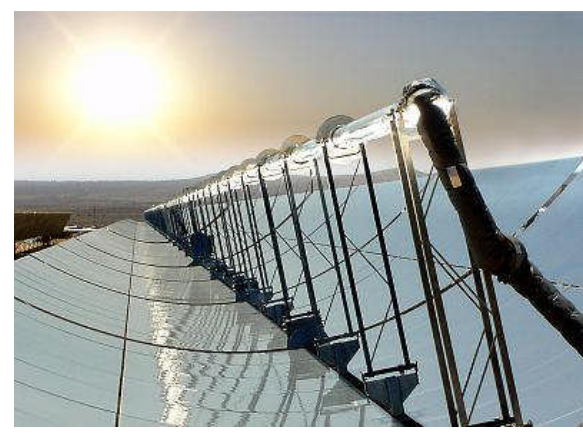

Figure 8. Parabolic mirror facets.

\section{MIRRORS}

The parabolic mirrors that reflect solar energy to the HCE use in this study will be low-iron laminated or monolithic glass mirrors. These mirrors are known to be reliable components that show no long-term degradation in reflective quality. Reflectivity of the mirrors is closely monitored to determine the frequency and method of mirror washing. Regular mirror washing has been proven to maintain mirror reflectivity at 


\section{WorleyParsons}

resources \& energy

\section{NATIONAL RENEWABLE ENERGY LABORATORY CSP PARABOLIC TROUGH PLANT COST ASSESSMENT}

installed conditions. More recent alternative mirror technology intended to drive down cost is also available.

\subsubsection{Heat Transfer Fluid System}

Heat transfer fluid is the link between the sun's radiation energy and the steam energy utilized in the power block. In a parabolic trough plant, HTF travels through a series of processes such as pumping, expanding, heating, cooling, and purifying. Circulation, expansion, ullage, and freeze protection are the primary HTF sub-systems.

The HTF selected for the reference plant is a high-temperature synthetic oil that has a proven operating history and is used in operating CSP trough plants and other heat transfer processes. It has a maximum operating temperature of $750^{\circ} \mathrm{F}\left(399^{\circ} \mathrm{C}\right)$ and a freezing temperature of $54^{\circ} \mathrm{F}\left(12.2^{\circ} \mathrm{C}\right)$. These properties are critical factors in the design of the HTF system. Because the HTF maximum temperature is the primary factor limiting the steam cycle efficiency, proper HTF selection is important in actual plant design.

Although having HTF that could reach temperatures above $950^{\circ} \mathrm{F}$ would be beneficial to the plant's performance, its use would significantly increase the capital cost by requiring special alloy piping in the solar field. In addition, the relatively high freezing temperature of this HTF will require a freeze protection system which consumes a significant amount of electricity or fossil energy to keep the fluid in a liquid state during the evening. More details on the handling of HTF are discussed throughout this section.

\section{HTF CiRCulation}

The solar collector system involves an extensive piping network which circulates HTF in a closed loop to and from the power block and solar field. This system is designed to maintain an equally distributed flow through all the SCAs so as to avoid low and high temperature areas. Variable speed pumps, quadrant control valves, loop balancing valves, and temperature sensors are used to control the "hot" HTF to a constant temperature.

Expansion loops will be located as required to maintain pipe stresses within the limits allowed by ASME B31.1 - Power Piping Code and to meet component manufacturer load limitations. Main supply and return header pipe running to/from the solar field sections and to/from the pumps range from 42inch to 24-inch nominal diameter. Solar field header pipe beginning at each section of loops (6 sections depicted in the solar field layout sketch above) which supply/return HTF to/from each loop range from 24-inch to 4-inch nominal diameter. All solar field HTF piping is insulated carbon steel and supported by pier-mounted pipe supports. Each loop of SCAs will be interconnected with 2.5-inch standard wall insulated carbon steel. Single and double ball joints will allow for independent SCA rotation while maintaining a fixed interconnecting pipe position.

Four (4) $-33 \%$ centrifugal type circulation pumps, each requiring $4000 \mathrm{hp}$ motors, will circulate the HTF in the closed loop system. They are the highest single parasitic load in the plant and will be driven by variable speed drives (VSD) in order to reduce their power requirements when the system flow is less than $100 \%$. In addition, a dedicated freeze protection circulation pump with a $200 \mathrm{hp}$ fixed speed motor will circulate HTF through the freeze protection heat exchanger. Both circulating pumps and the freeze protection pump are located on a common foundation and spill containment area underneath the pipe rack with a reserved motor/pump pull space for maintenance.

\section{HTF EXPANSION \& NITROgEN BLANKETING}

As the HTF is heated from its lowest allowable overnight temperature of $100^{\circ} \mathrm{F}\left(37.8^{\circ} \mathrm{C}\right)$ to its operating temperature of up to $740^{\circ} \mathrm{F}\left(393.3^{\circ} \mathrm{C}\right)$, the resulting large change in fluid volume requires 


\section{WorleyParsons}

resources \& energy

\section{NATIONAL RENEWABLE ENERGY LABORATORY CSP PARABOLIC TROUGH PLANT COST ASSESSMENT}

one 75,000 gallon $\left(284 \mathrm{~m}^{3}\right.$ ) expansion tank and six 75,000 gallon overflow tanks (same design as expansion tank) to accommodate this additional volume. During HTF warm-up the expansion tank reaches its max capacity and sends HTF to the first overflow tank and continues until all tanks are nearly full at full-load operation. As the HTF temperature decreases during shutdown, and the HTF contracts, an overflow tank transfer pump intermittently transfers HTF from the overflow tanks to the expansion tank until cold HTF temperature is reached and only the expansion tank is partially full. These pumps are located in a common containment area with the tanks.

Due to the heat reserve in the thermal storage system, the expansion system can be located on the cold side of the HTF cycle, which results in a cost saving with a reduction in wall thickness and a slight reduction in expansion/overflow tank capacity. During extended cloud transients, the thermal storage system will provide a buffer to maintain the plant at its "pre-cloud" load. During short-term cloud transients, the HTF system mass (HTF plus steel) will provide a buffer. Plants without storage may opt to locate the expansion system on the hot side to act as a more significant cloud buffer.

The expansion tank is also blanketed with nitrogen which serves to partially control the closed loop system pressure (similar to a bladder tank) and suppress HTF vapor formation by assuring the lowest pressure in the system remains above the HTF vapor pressure. The correct initial nitrogen blanketing pressure at the cold HTF condition, a function of expansion tank excess capacity, will assure that the tank pressure will be above the HTF vapor pressure when the nitrogen is compressed and heated by the HTF expansion. The nitrogen also guards against oxidation and contamination from air contact and eliminates a potentially explosive mixture. Oxidation will lead to a decrease in HTF heat transfer abilities and overall useable life of the fluid.

A bulk liquid nitrogen storage and vaporization system will be located adjacent to the expansion tank. Nitrogen will continuously be bled and replenished from the system due to the ullage system operation (further explained below).

\section{HTF ULLAGE SYSTEM}

The ullage system consists of heaters, coolers, flash tanks, storage tanks, pumps, drains, vents, and interconnecting piping and instrumentation. During operation the HTF breaks down into components having high and low boiling points as it is exposed to oxygen and/or overheated. The components with a low boiling point (low boilers) will be removed as vapors, along with other non-condensables and moisture (steam), out the top of the expansion tank and processed in the ullage system which releases this vaporous waste to atmosphere while recovering any high-quality liquid HTF. The components with high boiling points (high boilers) will be removed as liquid and sediment through the HTF flash system. The "good" HTF flashed vapor will be recovered and returned to the system, the remaining high boiler liquid waste and sediment will either be trucked off site or treated in the bioremediation area.

\section{HTF FREEZE PROTECTION}

The selected HTF freezes at $54^{\circ} \mathrm{F}\left(12.2^{\circ} \mathrm{C}\right)$, which is well above the Daggett area winter and/or nighttime temperatures. Once the SCAs stop transferring heat to the HTF and the HTF temperature drops significantly the freeze protection circulating pump circulates the HTF at approximately $10 \%$ of normal flow rate. Once a majority of the heat dissipates to atmosphere the HTF will be directed through a steam-to-HTF shell and tube condensing heat exchanger in order to keep it at approximately $100^{\circ} \mathrm{F}$ $\left(37.8^{\circ} \mathrm{C}\right)$. The steam source will be from the auxiliary boiler providing superheated steam which will be desuperheated with condensate spray before entering the heat exchanger. Alternatively the thermal storage system can be used to keep the HTF at the minimum temperature. Heat tracing will also be employed to protect small HTF piping, valves and instruments and/or where HTF may be stagnant. 
resources \& energy

\section{NATIONAL RENEWABLE ENERGY LABORATORY CSP PARABOLIC TROUGH PLANT COST ASSESSMENT}

\subsubsection{Power Cycle}

Typical CSP parabolic trough plants have a reheat Rankine power cycle driven by oil-to-water heat transfer. As described above, hot HTF flows from the solar field through a series of heat exchangers in the power block, which ultimately provides superheated high pressure steam to drive the $118 \mathrm{MWe}$ steam turbine generator.

Condensate is pumped through a series of low pressure closed feedwater heaters and into an open deaerating type feedwater heater used to remove oxygen from the system. This saturated and deaerated water is then sent to the deaerator storage tank, which serves as the suction for the feedwater pumps. The feedwater pump discharge is sent through a high pressure closed feedwater heater and into the economizer, evaporator and superheater. The steam from the steam generator train is admitted at $\sim 700^{\circ} \mathrm{F}\left(371^{\circ} \mathrm{C}\right)$ and $\sim 1325$ psia $(91.4$ bar) to the high pressure (HP) turbine. HP turbine exhaust is reheated in the oil-to-steam reheater where lower pressure $700^{\circ} \mathrm{F}$ steam is admitted to the low pressure (LP) turbine. LP turbine exhaust is then condensed in a wet surface condenser, using cool circulating water from a mechanical draft cooling tower, where the condensate is collected in the hotwell, from which the condensate pumps take suction.

Figure 9 below illustrates this process in more detail and includes high-level thermal storage and water treatment processes. This process flow diagram shows the relationship between all thermal process systems including HTF, water, steam, molten salt, and natural gas.

The electric generation side of the power cycle involves a generator, transformers, circuit breakers, switches, and supporting transmission equipment. These systems are discussed later in the report along with civil, structural, and instrumentation/control systems.

\section{HEAT BALANCE}

Given NREL's basic plant design criteria and WorleyParsons' assumptions, the reference plant's power cycle model was established. Conceptual Rankine cycle heat balances were modeled using General Electric's GateCycle $\odot$ software at three cases. The design case sets all equipment sizes based on peak ambient weather data as previously described. In addition, two off-design cases are modeled for winter and annual average ambient conditions. 
resources \& energy

\section{NATIONAL RENEWABLE ENERGY LABORATORY CSP PARABOLIC TROUGH PLANT COST ASSESSMENT}

Table 5. Heat balance output summary for reference plant. Not all model outputs are shown.

\begin{tabular}{|c|c|c|c|c|}
\hline \multicolumn{2}{|l|}{ Description } & \multirow{2}{*}{$\begin{array}{l}\begin{array}{l}\text { Design } \\
\text { Case }\end{array} \\
108.0 / \\
42.2\end{array}$} & \multirow{2}{*}{$\begin{array}{l}\begin{array}{l}\text { Winter } \\
\text { Average }\end{array} \\
58.9 / 14.9\end{array}$} & \multirow{2}{*}{$\begin{array}{l}\begin{array}{l}\text { Annual } \\
\text { Average }\end{array} \\
81.5 / 27.5\end{array}$} \\
\hline Ambient Conditions & DB Temperature $\left({ }^{\circ} \mathrm{F} /{ }^{\circ} \mathrm{C}\right)$ & & & \\
\hline & Relative Humidity (\%) & $17 \%$ & $29 \%$ & $23 \%$ \\
\hline System Performance & Gross Power Output (kW) & 117,994 & 119,166 & 118,906 \\
\hline \multirow{2}{*}{ HTF from Solar Field } & Flow (lb/hr) & $10,253,326$ & $10,254,841$ & $10,254,837$ \\
\hline & Temp $\left({ }^{\circ} \mathrm{F} /{ }^{\circ} \mathrm{C}\right)$ & $740 / 393.3$ & $740 / 393.3$ & $740 / 393.3$ \\
\hline \multirow{4}{*}{ HP Steam to STG } & Flow (lb/hr / kg/min) & $\begin{array}{l}1,053,158 / \\
7,961\end{array}$ & $\begin{array}{l}1,053,185 / \\
7,962\end{array}$ & $\begin{array}{l}1,053,185 / \\
7,962\end{array}$ \\
\hline & Temp $\left({ }^{\circ} \mathrm{F} /{ }^{\circ} \mathrm{C}\right)$ & $700 / 371$ & $700 / 371$ & $700 / 371$ \\
\hline & Press (psia / bar) & $1325 / 91.4$ & $1325 / 91.4$ & $1325 / 91.4$ \\
\hline & Enthalpy (BTU/lb) & 1301 & 1301 & 1301 \\
\hline \multirow{4}{*}{ HRH Steam to STG } & Flow (lb/hr / kg/min) & $\begin{array}{l}910,716 / \\
6,885 \\
\end{array}$ & $\begin{array}{l}910,715 / \\
6,885 \\
\end{array}$ & $\begin{array}{l}910,715 / \\
6,885 \\
\end{array}$ \\
\hline & Temp $\left({ }^{\circ} \mathrm{F} /{ }^{\circ} \mathrm{C}\right)$ & $700 / 371$ & $700 / 371$ & $700 / 371$ \\
\hline & Press (psia / bar) & $362 / 25$ & 362 / 25 & $362 / 25$ \\
\hline & Enthalpy (BTU/lb) & 1365 & 1365 & 1365 \\
\hline \multirow{4}{*}{$\begin{array}{l}\text { From Condenser } \\
\text { Hotwell }\end{array}$} & Flow (lb/hr / kg/min) & $\begin{array}{l}732,054 / \\
5,534 \\
\end{array}$ & $\begin{array}{l}721,732 / \\
5,456 \\
\end{array}$ & $\begin{array}{l}726,588 / \\
5,943\end{array}$ \\
\hline & Temp $\left({ }^{\circ} \mathrm{F} /{ }^{\circ} \mathrm{C}\right)$ & $109 / 42.8$ & $95 / 35$ & $101 / 38.3$ \\
\hline & Press (psia / bar) & $\begin{array}{l}1.25 / \\
0.0861\end{array}$ & $0.81 / 0.0558$ & $\begin{array}{l}0.99 / \\
0.0683\end{array}$ \\
\hline & Enthalpy (BTU/lb) & 77.1 & 62.6 & 69.5 \\
\hline
\end{tabular}




\title{
WorleyParsons
}

\author{
resources \& energy
}

NATIONAL RENEWABLE ENERGY LABORATORY

CSP PARABOLIC TROUGH PLANT COST ASSESSMENT

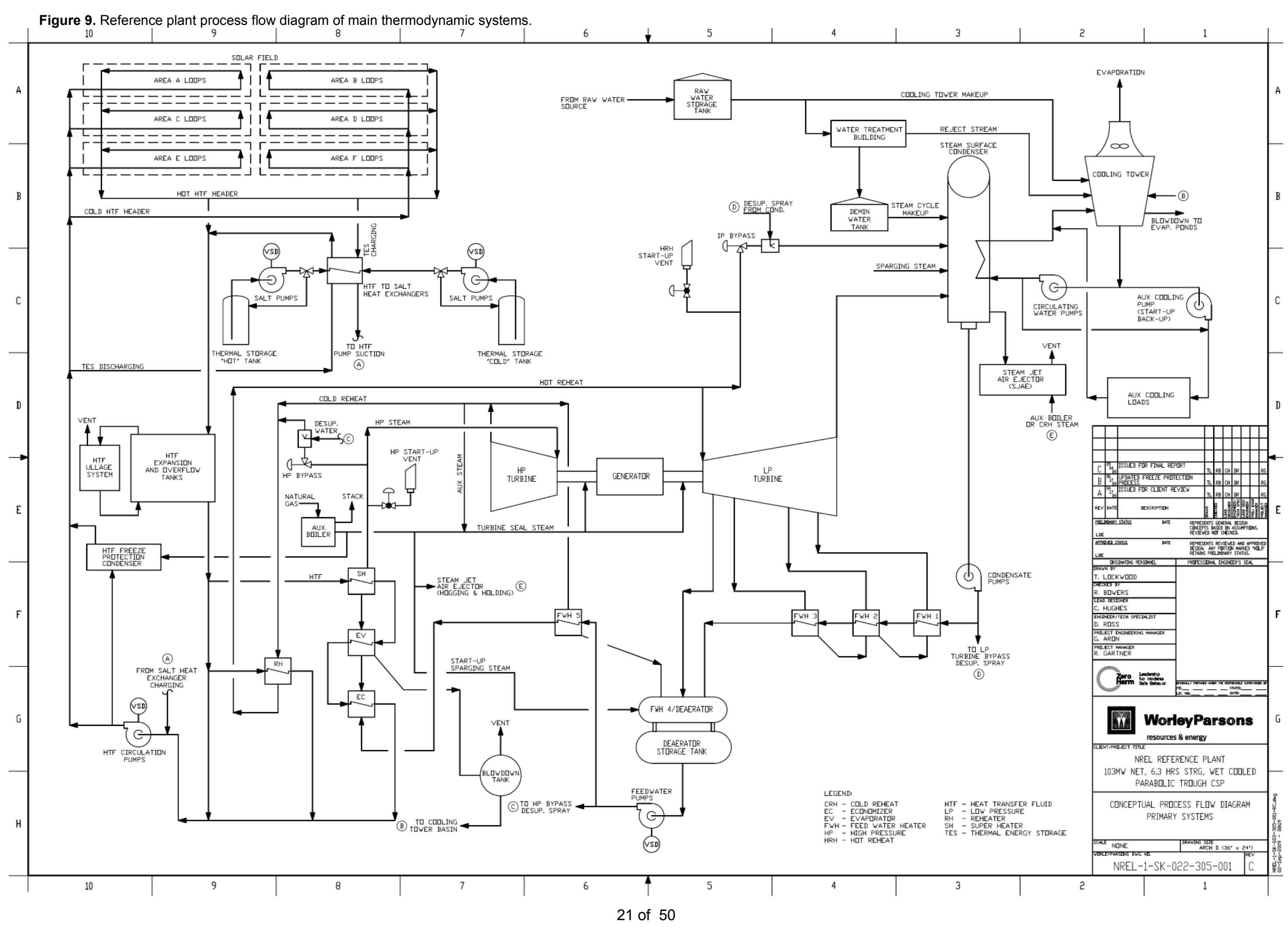




\title{
WorleyParsons
}

resources \& energy

\section{NATIONAL RENEWABLE ENERGY LABORATORY CSP PARABOLIC TROUGH PLANT COST ASSESSMENT}

\begin{abstract}
WATER BALANCE
Water balance calculation results for the three heat balance cases are shown in Figures 10 to 12 below. The water balance is representative of simultaneous operating consumers at full turbine output for a given ambient condition. Intermittent and emergency users (firewater, hose streams, safety showers etc.) are not running during normal operation and are therefore excluded from the water balance. Mirror wash water consumption is shown coincident to Rankine cycle operation for clarity, although it will not be performed so.

The primary water consumer is cooling tower makeup which is over $90 \%$ of the plant's instantaneous water consumption. Annually, cooling tower makeup equals about $93 \%$ of the plant's total annual water consumption. Mirror washing is the next largest consumer at nearly $4 \%$. The remaining water consumption is attributed to cycle makeup, blowdown quench, domestic (service water), and waste streams from the demineralized water treatment system.

Major assumptions are listed in each water balance case; primarily the cooling tower cycles of concentration $(\mathrm{COC})$ which is the most influential input. Without having site specific water quality data, a representative five cycles of concentration $(\mathrm{COC})$ was assumed. The overall water consumption is largely dependent on COC. Although poor raw water quality can be pretreated to save water, capital cost for pretreatment systems can become very expensive depending on the raw water constituents. No pretreatment system is included in the cost estimate for the reference plant.
\end{abstract}




\title{
Wi. WorleyParsons
}

\author{
resources \& energy
}

NATIONAL RENEWABLE ENERGY LABORATORY

CSP PARABOLIC TROUGH PLANT COST ASSESSMENT

Figure 10. Design case water balance at $108^{\circ} \mathrm{F}\left(42.2^{\circ} \mathrm{C}\right) \mathrm{DB}$ and $71.3^{\circ} \mathrm{F}\left(21.8^{\circ} \mathrm{C}\right) \mathrm{WB}$ ambient temperatures. Diagram is high-level and not inclusive of all water system processes
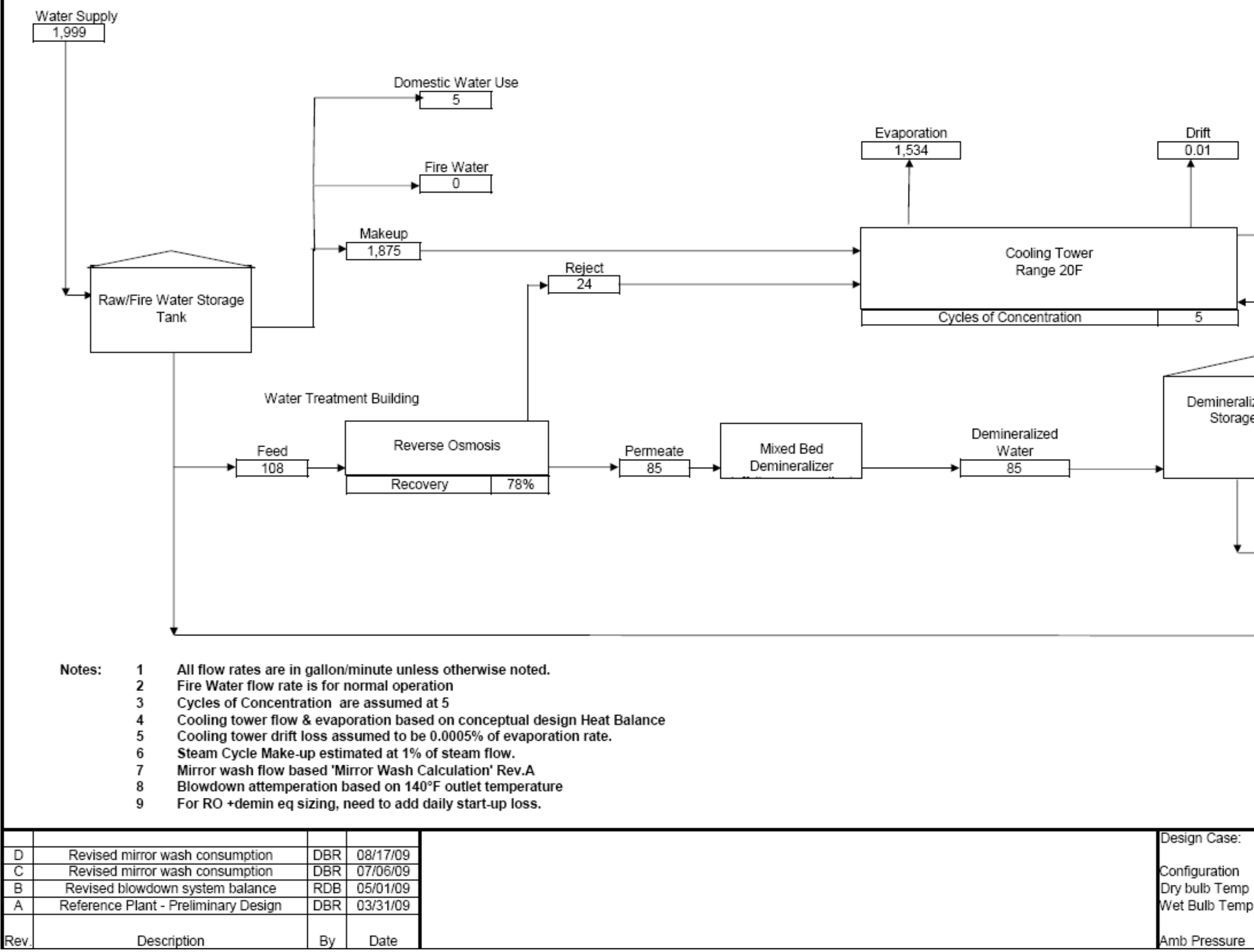

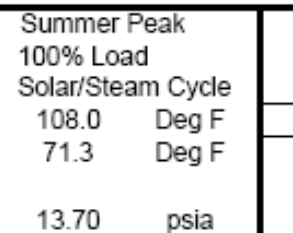

WorleyParsons 


\section{Wi. WorleyParsons}

resources \& energy

NATIONAL RENEWABLE ENERGY LABORATORY

CSP PARABOLIC TROUGH PLANT COST ASSESSMENT

Figure 11. Annual average case water balance at $81.5^{\circ} \mathrm{F}\left(27.5^{\circ} \mathrm{C}\right) \mathrm{DB}$ and $58.1^{\circ} \mathrm{F}\left(14.5^{\circ} \mathrm{C}\right) \mathrm{WB}$ ambient temperatures. Diagram is high-level and not inclusive of all water system processes

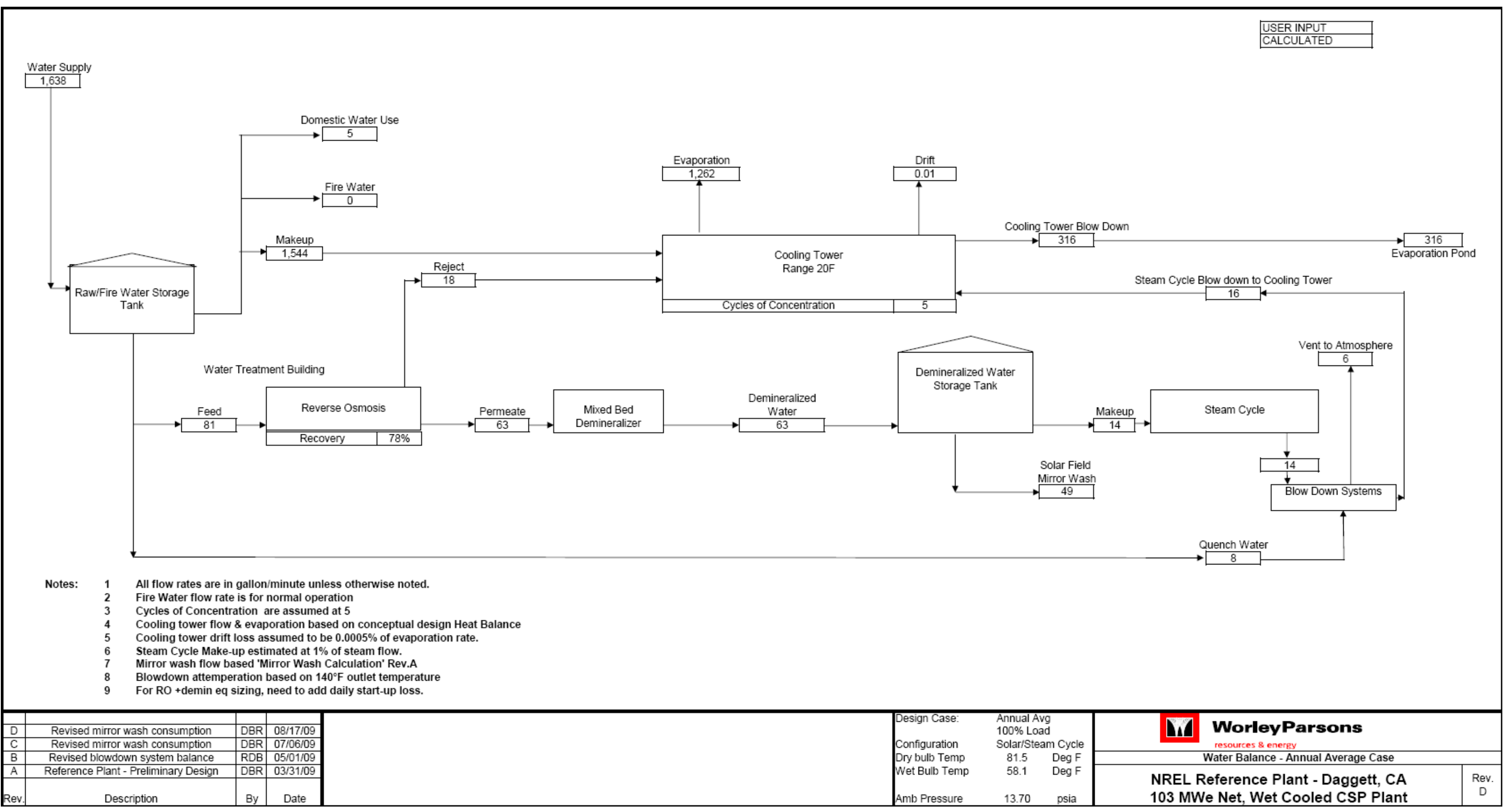




\section{WW WorleyParsons}

resources \& energy

NATIONAL RENEWABLE ENERGY LABORATORY

CSP PARABOLIC TROUGH PLANT COST ASSESSMENT

Figure 12. Winter average case water balance at $58.9^{\circ} \mathrm{F}\left(14.9^{\circ} \mathrm{C}\right) \mathrm{DB}$ and $44.4^{\circ} \mathrm{F}\left(6.9^{\circ} \mathrm{C}\right) \mathrm{WB}$ ambient temperatures. Diagram is high-level and not inclusive of all water system processes.

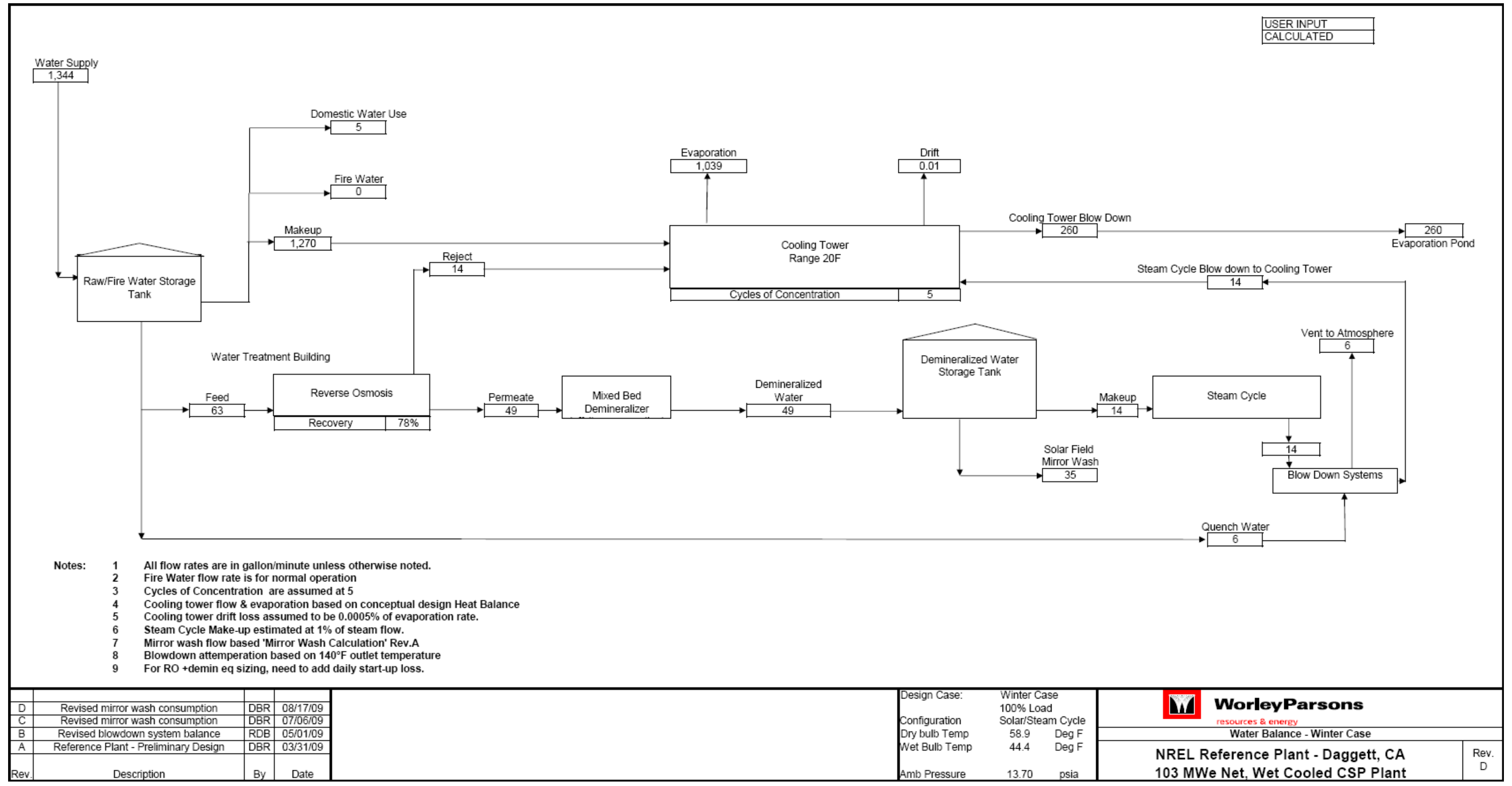




\title{
WorleyParsons
}

resources \& energy

\author{
NATIONAL RENEWABLE ENERGY LABORATORY \\ CSP PARABOLIC TROUGH PLANT COST ASSESSMENT
}

\begin{abstract}
FEEDWATER
The reference plant feedwater pumps take suction off the deaerator storage tank and discharges the feedwater through one high pressure heater and into the economizer. Two full capacity centrifugal-type ring section multistage feedwater pumps with $3000 \mathrm{hp}$ motors with VSD hydraulic couplings are the primary pressure source in the steam cycle. These pumps sit at grade below the elevated deaerator storage tank.
\end{abstract}

\section{Solar SteAM Generator}

The solar steam generator (SSG) transfers solar energy from the HTF to feedwater, generating steam used in a traditional reheat Rankine cycle for electricity generation. The steam generator system uses traditional shell and tube heat exchangers. The hot oil from the solar collector field passes through one $1 \times 100 \%$ economizer, $2 \times 50 \%$ evaporators, $1 \times 100 \%$ superheater and $2 \times 50 \%$ reheaters. The economizer acts as a preheater to raise the incoming high pressure feedwater close to saturation temperature. In the evaporator, saturated high pressure feedwater is boiled, sent through a separator (internal to kettle boiler) and on to the superheater to produce $\sim 700^{\circ} \mathrm{F}$ $\left(371^{\circ} \mathrm{C}\right)$ superheated steam for HP turbine admission. HP turbine exhaust, or cold reheat, is sent to the reheater, raised to $\sim 700^{\circ} \mathrm{F}\left(371^{\circ} \mathrm{C}\right)$ and admitted to LP turbine.

\section{STEAM TURBINE ISLAND}

One $118 \mathrm{MWe}$ rated steam turbine with reheat is selected for the Daggett reference plant. The reference turbine has a single flow LP section with last stage blades designed for wet surface condensing. The generator is located between the HP and LP sections where the LP rotor directly couples with the generator and the HP turbine rotor mates with a speed reducing gear box for generator connection. All turbine auxiliaries provided by the steam turbine generator (STG) equipment manufacturer include: turbine modules, gearbox, stop/control valves, electrical generator, lube oil skid, control oil skid, seal/gland steam condenser skid, stand alone control system and an outdoor noise enclosure. All auxiliaries work together to maintain maximum turbine performance.

\section{CONDENSATE}

LP steam turbine exhaust is condensed in a wet cooled surface condenser and pumped by a 350 $\mathrm{hp}$ vertical centrifugal can pump from the condenser hotwell, through three(3) closed LP feedwater heaters and into the deaerator. Additionally condensate is used as desuperheating spray for the LP turbine bypass system and aux boiler steam admission to the HTF freeze protection condenser. The deaerator and associated storage tank are supported $\sim 70$ feet (21.3 meters) above grade to provide a sufficient net positive suction head (NPSH) for the feedwater pumps.

\section{Circulating Cooling Water}

The primary components in the circulating water system include a forced draft five-cell cooling tower, circulating pumps/pipe, and a dedicated chemical feed system. Steam condensing temperature in a wet-cooled plant is driven primarily by ambient wet bulb temperature. Specifically, cooling water rejects its heat by latent heat of evaporation through the counter flow water-to-air cooling tower. The two-speed $250 \mathrm{hp}$ tower fans force ambient air up through its cells where the cooling water counter flows downward via gravity and is dispersed over several 


\title{
WorleyParsons
}

resources \& energy

\author{
NATIONAL RENEWABLE ENERGY LABORATORY \\ CSP PARABOLIC TROUGH PLANT COST ASSESSMENT
}

thousand square feet of cooling tower fill (honeycomb type trays) which maximize heat transfer. Large vertical turbine type pumps, mounted on a concrete intake structure providing adequate NPSHA, circulate approximately $67,000 \mathrm{gpm}(4,227 \mathrm{liter} / \mathrm{sec})$ of cooling water through a 48 -inch underground pre-stressed concrete pipe header from the cooling tower basin to the cold side of the condenser and back to the top of the tower just below its fan deck.

The cooling tower has three sources of water loss: evaporation, blowdown, and drift (refer to water balances in figures 10 to 12 above). Evaporation is by far the largest loss and it basically fixed for a given duty and set of ambient conditions. Blowdown (driven by COC) and drift (water droplets leaving the tower and not fully evaporated) are the smaller water losses of the tower. Altogether, these losses must be replaced and therefore constitute the makeup flow to the tower basin. For the reference plant, untreated cooling tower makeup water will be gravity fed from the nearby raw water storage tank to the cooling tower basin. A chemical feed storage building (complete with tanks, totes, metering pumps, and chemicals) injects chemicals into the tower basin to prevent scaling, and micro-biological fouling in the pipe, condenser and tower, which ultimately blocks the tower fill and diminishes the tower's heat transfer capability.

\subsubsection{Thermal Energy Storage}

Thermal energy storage (TES) provides the ability to extend the plant operating hours beyond that available from DNI. The reference plant is designed for 6.3 hours (or $1988 \mathrm{MWth}$-hrs) of thermal storage at full turbine output. Energy is stored in large insulated tanks containing molten salt made up of $60 \%$ (by weight) sodium nitrate and $40 \%$ potassium nitrate. The reference plant has two tank sets with one 'hot' and one 'cold' tank per set. As seen in the process flow diagram sketch above, during TES charging hot HTF from the solar field exchanges heat with cold salt from the cold tank as it flows through an elevated heat exchanger and into the hot tank. The reverse happens during TES discharging. Hot salt exchanges heat with cold HTF where it is then sent to the solar steam generators for power generation. TES primary equipment includes salt to oil heat exchangers (3 per tank set), vertical pumps with variable frequency drive (VFD) motors mounted on top of the tanks ( 3 per tank), valves and piping all supported on an elevated pipe rack at full tank height to allow draining which prevents salt freezing during TES offline hours.

Since the plant is designed with the ability to fully charge TES while generating electricity at full capacity, the solar field mirror area must increase to accommodate the larger energy demand. A plant with storage will have a larger solar multiple (previously defined) than a plat

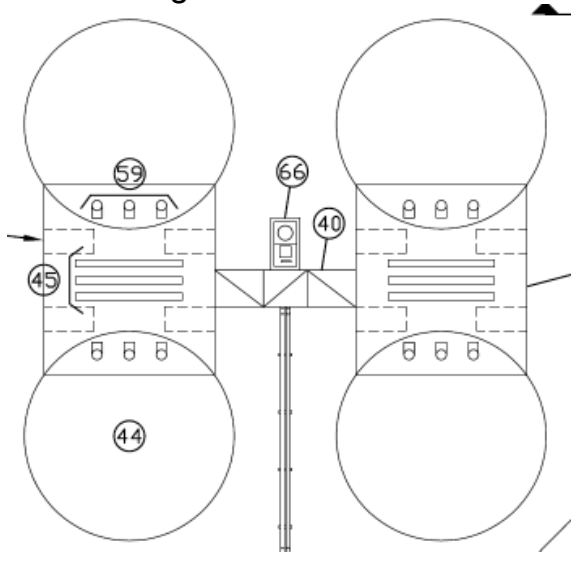

Figure 13. Typical two-tank molten salt TES system. without to accommodate the added energy delivered to storage while the power block operates at full load. When the power block is generating electricity and the TES is charging, one portion of the field delivers energy to the TES and the other to the steam generator train. 


\title{
WorleyParsons
}

resources \& energy

\author{
NATIONAL RENEWABLE ENERGY LABORATORY \\ CSP PARABOLIC TROUGH PLANT COST ASSESSMENT
}

\subsubsection{Balance of Plant}

Systems supporting the primary thermal systems above are called "balance of plant" systems. These include, but are not limited to: fire protection, auxiliary cooling, auxiliary steam, blowdown, drains, water treatment, raw water, demineralized water, potable water, wastewater, sanitary drains, fuel gas, and compressed air. Systems such as the sampling, condenser air removal, and steam turbine auxiliaries are briefly mentioned in other sections of the report.

\section{FIRE PROTECTION}

All fire prevention and fire protection systems will be designed to protect personnel from injury and prevent property damage. The primary fire hazard of a parabolic trough plant is combustion of leaking HTF. Reference plant fixed fire suppression systems (sprinkler or deluge) protect the HTF expansion tank area, HTF ullage area, HTF pump area, STG area, lubricating oil skid, fire pump house, administration/control building, warehouse/maintenance building, water treatment building, generator step-up transformer, and the auxiliary transformers. Some of these fixed systems may not be necessary depending on the Owner's insurer requirements; however all are included to provide a reference plant design.

The largest fixed system demand is the outdoor HTF expansion tank area which has a concrete firewall between every two tanks to divide the protection area and reduce flow demand. This demand plus hose stream flow requires a $3000 \mathrm{gpm}$ (189 liter/sec) firewater pump. One electric motor driven and one diesel engine driven $100 \%$ capacity pump are included in the reference plant. A small $5 \mathrm{hp}$ jockey pump is also needed to maintain pressure in the fire main at all times. National Fire Protection Association (NFPA) code recommends that a 2-hour firewater supply must be stored onsite and reserved for emergencies. Thus 360,000 gallons $\left(1363 \mathrm{~m}^{3}\right)$ of firewater is reserved via a standpipe in the raw water storage tank.

The firewater delivery system includes fire hydrants and monitors, post indicating valves, manually controlled valve houses, self detecting and actuating deluge systems and an underground loop main that feeds all firewater users. Buildings will be equipped with alarms, sensors, and fire extinguishers per NFPA code.

Most constructed CSP plants will require a fire risk evaluation, consultation with an insurance company, evaluation of potential on-site fire brigade and emergency plan to determine the best approach to fire protection and prevention of the solar field. It is expected that fire protection for the solar field will, for the most part, be provided by zoned isolation of the HTF lines in the event a rupture of any line results in a fire. A HTF fire will most likely be allowed to extinguish itself naturally since the remainder of the solar collector field consists of nonflammable material (aluminum, steel, and glass) and the separation between SCAs is significant. Therefore, no solar field fire protection equipment is included in the cost estimate.

\section{AUXILIARY COOLING}

Certain rotating equipment requires cooling water to maintain lubricating oil temperature specified by the manufacturer. Turbine lubricating oil, turbine generator, sample panel, HTF pumps, TES pumps, feedwater pumps and possibly TES tank foundations all require auxiliary cooling water. The auxiliary cooling is accomplished via a closed loop cooling system that absorbs heat from each user's cooler and rejects the combined heat in a common plate-and-frame heat exchanger. 


\title{
WorleyParsons
}

resources \& energy

\author{
NATIONAL RENEWABLE ENERGY LABORATORY \\ CSP PARABOLIC TROUGH PLANT COST ASSESSMENT
}

Daggett's high ambient temperatures allow the cooling water system to operate without any glycol additive. The heat sink for the closed loop cooling system is the circulating water system. A small stream of circulating water is drawn from the system and routed to the closed loop cooling system heat exchangers and back to the cooling tower. During start-up when the circulating water pumps are not operating, an auxiliary cooling water pump (located in the circulating water intake structure) is used to cool the heat exchangers.

\section{AUXILIARY STEAM}

A natural gas fired auxiliary boiler is needed to supply steam during plant startup and overnight to maintain STG seals, condenser vacuum and occasionally for HTF freeze protection. The primary auxiliary steam user is the vacuum Hogger which uses steam to evacuate the condenser during startup. Once vacuum is established, the Steam Jet Air Ejector (SJAE) holds the vacuum to condenser operating conditions. The auxiliary boiler duty is sized for the largest flow which is the HTF freeze protection condenser, but at the required SJAE temperature and pressure. Secondary auxiliary steam users include the gland steam system for turbine sealing and the deaerator for startup sparging steam.

\section{BLOWDOWN}

Steam cycle chemistry is partially maintained by continuous blowdown of saturated liquid from the evaporator. Blowdown is flashed in the blowdown tank where the left over condensate is quenched by raw water, collected in the blowdown sump and pumped to the cooling tower basin to reduce cooling tower makeup.

\section{VENTS AND DRAINS}

All steam piping has vents and drains for pressure bleeding, air venting and condensate draining. Drain lines are critical for steam system warm-up and condensate removal to avoid turbine water induction.

\section{WATER TREATMENT}

No pre- or post-water treatment is included in the reference plant design. Plant water treatment includes demineralized water, potable water, cooling tower chemical feed, and cycle chemical feed. Each of these systems is briefly discussed in its own section.

\section{RAW WATER}

Three- $50 \%$ capacity centrifugal type well water forwarding pumps will supply the raw water storage tank from offsite wells. The underground supply pipeline is 10-inch high density polyethylene (HDPE) plastic pipe and extends from the raw water tank to an assumed 200 feet (61 meters) off the property boundary north of the access gate. Three (3) 10-inch diameter wells, 500 -feet (152 meters) deep, 200 feet (61 meters) off the property boundary have been included in the cost estimate. Assuming well water as the raw water source is a significant assumption. Raw water supply is completely site dependent and could vary in source (surface, well, utility), quality, and quantity. 


\title{
WorleyParsons
}

resources \& energy

\author{
NATIONAL RENEWABLE ENERGY LABORATORY \\ CSP PARABOLIC TROUGH PLANT COST ASSESSMENT
}

The field-erected carbon steel raw water storage tank is sized to provide 14 hours for cooling tower makeup, blowdown quench, demineralized treatment system, and service water; as well as the aforementioned reserved firewater volume. Service water pumps typically supply blowdown quench water, plant hose streams and demineralized and potable treatment systems.

\section{DEMINERALZED WATER}

The demineralized system, located in the water treatment building, will use electrostatic deionization equipment with multimedia filtration and reverse osmosis processes. Water treatment design is very specific to the incoming water quality. A general water quality was assumed to arrive at a typical system for the reference CSP trough plant. The plant's two demineralized water users are mirror washing and steam cycle makeup. Demineralized water is stored in two field-erected lined carbon steel water tanks. Water storage capacity holds up to 30 hours of cycle makeup, 2 days of cycle makeup for startup, and 2 days of solar field mirror washing.

Steam cycle makeup replaces cycle blowdown. Cycle makeup flow is significantly higher during startup than normal operation due to the larger blowdown flows and condensate consumption for bypass desuperheat spray.

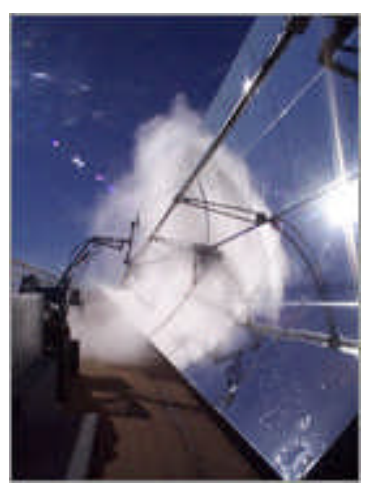

Figure 14. High pressure mirror wash
Mirror wash water is transferred from the storage tanks to the truck fill station. Although reverse osmosis filtered water can be used, demineralized water quality is the best quality water for mirror washingleaving no spots or scaling which could reduce reflectivity. Mirror washing profiles are estimated based on reports from the existing Solar Electric Generating Station (SEGS) at Kramer Junction California. In the summer, deluge spray trucks and high pressure rigs wash the field nightly to maintain mirror reflectivity to its installed value. In off-summer months, mirror washing is dramatically decreased due to lower wind speeds, natural cleaning by precipitation, and less frequent plant operation. Wash trucks will fill their water tank and fuel tank at a common station. An aboveground diesel storage tank with built-in pump will provide several months of fuel for wash trucks and general facility maintenance trucks. The canopy covered fill station will have dedicated parking spaces for the extra large wash trucks.

\section{Potable WATER}

A potable water treatment skid will be located in the water treatment building and supply a small shop fabricated potable water tank with a 36-hour supply. Potable water forwarding pumps will supply typical users such as building facilities (sinks and showers), eye washes, and safety showers.

\section{OILY WASTEWATER}

Spill containment will be provided for HTF pumps, expansion tanks, and ullage systems to collect possible HTF leaks and/or pump lubrication oil leaks. Containment is an open concrete curbed area sloping to a low point drain sump. Discharge from the HTF containment areas cannot be tied into the oily waste water system because HTF is heavier than water, whereas traditional oilwater separators used at power plants operate on the opposite principle. No HTF-laden water 


\title{
WorleyParsons
}

resources \& energy

\author{
NATIONAL RENEWABLE ENERGY LABORATORY \\ CSP PARABOLIC TROUGH PLANT COST ASSESSMENT
}

waste system has been included in the cost estimate; it is assumed that waste hauling trucks will periodically remove such waste water, although an alternate solution may be possible. Non-HTF oily waste water from truck fueling area, large transformer areas and STG lube oil areas will be routed to a common underground oil-water separator where the effluent water is then pumped to the cooling tower basin to reduce make-up water.

\section{SANITARY DRAINS}

Personnel sanitary waste facilities will discharge to the onsite septic tank located underground just outside of the water treatment building. Effluent will distribute across the adjacent leach field. Waste hauling trucks will periodically clean out the septic tank.

\section{FUEL GAS}

The reference plant single natural gas user is the auxiliary boiler. It is assumed that a nearby natural gas pipeline is available for interconnection. A 1.5-inch carbon steel supply line, locally regulated at the interconnection, will feed fuel gas to the auxiliary boiler with secondary regulation at the boiler.

\section{Compressed AIR}

Two redundant oil-free rotary screw type air compressors with an air dryer and receiver tank will be located in the water treatment building. Small bore (less than 2" nominal diameter) stainless steel piping will supply instrument and service air throughout the power block for control valve actuation, instrument control, and general operator service. No instrument or service air will be installed in the solar field. All solar field HTF valves will be motor driven or manual.

\subsection{Electrical System Descriptions}

The electrical systems will consist of a generator with step-up transformer, an auxiliary supply for the power block, a distribution system for the solar field, and a transmission tie line with an interconnecting substation. The generator voltage is $13.8 \mathrm{kV}$, the step-up transformer will be $13.8 / 230 \mathrm{kV}$, the transmission tie line will be $230 \mathrm{kV}$ and the auxiliary power block and solar distribution systems will be both $4160 \mathrm{v}$ and $480 \mathrm{v}$.

A brief description of each primary system and its sub-systems will be discussed throughout this section. Below is a list of the major electrical equipment which make up the reference plant design. Bulk mechanical materials such as cable, connectors, panel boards etc. are not listed at this design level, but are included in the cost estimate. 


\section{WorleyParsons}

resources \& energy

NATIONAL RENEWABLE ENERGY LABORATORY CSP PARABOLIC TROUGH PLANT COST ASSESSMENT

Table 6. Major electrical equipment list for Daggett reference plant.

\begin{tabular}{|l|l|}
\hline EQUIPMENT NAME & QTY \\
\hline TRANSFORMERS & \\
\hline Generator Step-Up Transformer & 1 \\
\hline Unit Auxiliary Transformer & 2 \\
\hline Station Service Transformers & 9 \\
\hline Excitation Transformer & 1 \\
\hline Solar Field Transformers & 9 \\
\hline Solar Collector Drive Power Converters & 1208 \\
\hline Emergency Transformer & 1 \\
\hline CIRCUIT BREAKERS & \\
\hline Generator Circuit Breaker & 1 \\
\hline Main Circuit Breaker & 1 \\
\hline SWITCHES & \\
\hline Circuit Switcher (switchyard) & 1 \\
\hline Main Disconnect Switch & 4 \\
\hline Transmission Line Disconnect Switch & 2 \\
\hline Generator Disconnect Switch & 1 \\
\hline Automatic Transfer Switch (for back-up battery power) & 2 \\
\hline OTHER EQUIPMENT & \\
\hline Isolated Phase Bus Duct (IPBD) & Lot \\
\hline Metering Current Transformers (CTs) & 3 \\
\hline Metering Potential Transformers (PTs) & 3 \\
\hline Control Relays & Lot \\
\hline Ground Grid & Lot \\
\hline Distributed Control System & 1 \\
\hline Uninterrupted Power Supply (UPS) - Balance of Plant & 1 \\
\hline $\begin{array}{l}\text { Power Distribution Center (PDC1A) with Switchgear and Motor Control } \\
\text { Centers (MCC) - Cooling Tower \& TES Areas }\end{array}$ & 1 \\
\hline $\begin{array}{l}\text { Power Distribution Center (PDC2A) with Switchgear and Motor Control } \\
\text { Centers (MCC) - STG \& HTF Areas, includes ESS Switchgear }\end{array}$ & 1 \\
\hline
\end{tabular}




\section{Wh WorleyParsons}

resources \& energy

NATIONAL RENEWABLE ENERGY LABORATORY

CSP PARABOLIC TROUGH PLANT COST ASSESSMENT

Figure 15. Conceptual electrical one-line diagram including all $4160 \mathrm{~V}$ connected equipment. Sheet 1 .

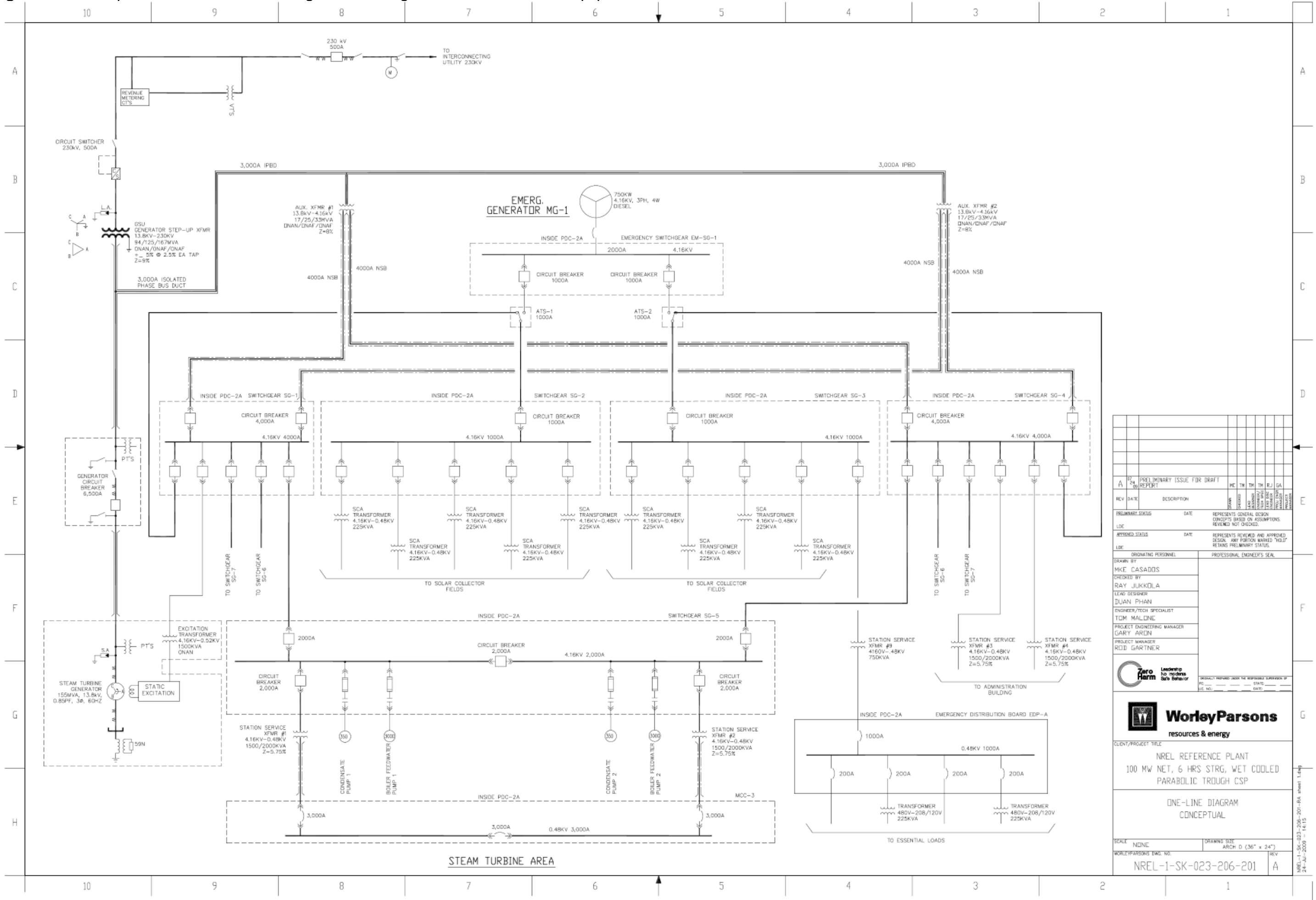




\section{WII WorleyParsons}

resources \& energy

NATIONAL RENEWABLE ENERGY LABORATORY

CSP PARABOLIC TROUGH PLANT COST ASSESSMENT

Figure 16. Conceptual electrical one-line diagram including all $4160 \mathrm{~V}$ connected equipment. Sheet 2.

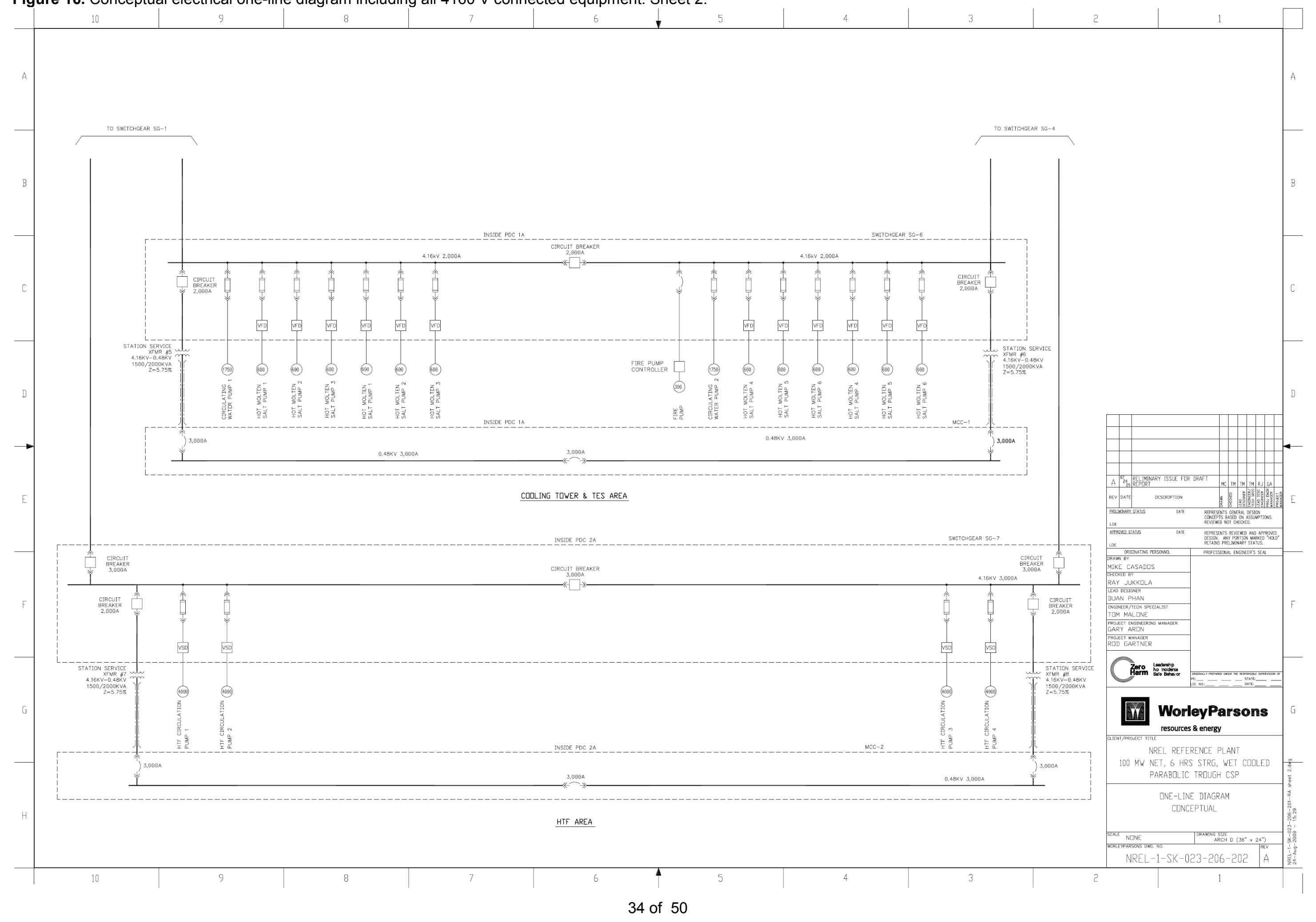




\section{WorleyParsons}

resources \& energy

NATIONAL RENEWABLE ENERGY LABORATORY

CSP PARABOLIC TROUGH PLANT COST ASSESSMENT

\subsubsection{Transformers}

The generator step-up (GSU) transformer will be 125 MVA and connected to the generator via an isophase bus duct. An additional T-connected isophase bus duct will connect the two auxiliary transformers (25 MVA) to the isophase bus duct on the low side of the GSU. These transformers will be set up to split the load under normal operating conditions, but will be able to pick up the entire load if necessary through tie breakers between the switchgear and motor control centers (MCC). There will be two power distribution center (PDC) in which the switchgear and MCC's will be located. A $750 \mathrm{~kW}$ emergency generator will be provided to serve the critical loads including the SCA's in the solar field and essential loads in the power block area.

\subsubsection{Solar Field Power Distribution}

The solar field will be served from the $4160 \mathrm{v}$ switchgear in the power block PDC. There will be nine $225 \mathrm{kva}, 4160 \mathrm{v}-480 \mathrm{v}$ transformers with adjacent 480v panelboards. The panelboards will provide individual feeds to subpanels to serve the SCA's. The cables to serve the transformers will be undergrounded in duct banks.

\subsubsection{Switchyard}

The grid tie line will be $230 \mathrm{kV}$ connecting the generator step-up transformer through an interconnecting substation to the utility grid. This will be a single line connection with breaker and disconnect switches.

\subsection{Instrumentation and Control System Descriptions}

Instrumentation and controls are provided to monitor and control the solar collection field and the power block equipment. The plant control system consists of two functional systems: a distributed control system (DCS) for the power block including the HTF system, and a solar field control (SFC) system for the solar field equipment.

\subsubsection{Power Block System Controls}

All plant control systems are microprocessor-based. All key system parameters are monitored, controlled, displayed, alarmed, recorded and trended. The system has a distributed architecture comprised of standard technology including Ethernet and serial communications with standard communications protocols such as TCP/IP and MODBUS TCP/IP. 


\section{WorleyParsons}

resources \& energy

NATIONAL RENEWABLE ENERGY LABORATORY

CSP PARABOLIC TROUGH PLANT COST ASSESSMENT

The system is based on Windows-compatible work stations and servers for operator interface and system engineering functions. Additional operator interfaces can be placed in local control centers, supervisor's offices, etc. The system engineering workstations also support all operator station functions.

Independent process controllers are provided for major plant systems including: HTF, balance of plant, steam generation, etc. Process controllers may be distributed to local control centers or other remote concentrations throughout the plant.

\subsubsection{Power Block Distributed Control System (DCS)}

\section{Plant System ContRol}

The DCS provides control functions for power generation either manually or semi-automatically. The control system provides automatic coordinated control, turbine follow, sliding pressure, and manual control configurations. The DCS controls all plant systems including: condensate/feedwater and steam, turbine / generator and heat transfer fluid. Integration of vendor supplied programmed logic controllers (PLC) and controls are seamless with the process control and information management system.

The DCS monitors and controls the following auxiliary systems:

- Auxiliary boiler including: fuel systems, burner management, combustion air, furnace draft and selective catalytic reduction (SCR).

- Water treatment system through a PLC-based control system provided by the equipment supplier.

- Diesel generator through a PLC-based control system provided by the Diesel Generator supplier.

- Circulating water system

- Closed Cooling Water System

- Condenser Vacuum System

- Chemical Feed Systems

\section{TIME SYNCHRONIZATION}

A GPS time synchronization system is supplied with the DCS. IRIG B signals from this system shall be used to synchronize time in all DCS equipment as well as the solar field control system. This time signal is used in the algorithm for calculating the position of the sun and manoeuvring the solar collectors.

\subsubsection{Power Block Control Room and Electronics Room}

\section{CONTROL ROOM OPERATOR INTERFACE}

The control room design is a soft DCS display-based operator interface consisting of multiple operator workstations, and a DCS server/workstation cabinet. A common control room is provided for the power block and solar field operator displays. 


\title{
WorleyParsons
}

resources \& energy

\author{
NATIONAL RENEWABLE ENERGY LABORATORY \\ CSP PARABOLIC TROUGH PLANT COST ASSESSMENT
}

An auxiliary benchboard control panel is provided for hardwired trip pushbuttons for the steam turbine trip and auxiliary boiler trip, direct steam generator level indication, direct hardwired operator interface with the turbine direct current (DC) oil pumps, direct hardwired operator interface with the emergency diesel generator, and turbine synchronization switches and synchroscope.

Visual and audible alarms are provided to alert the operator of abnormal operating conditions and to provide a record of operations events. All alarms are recorded in the plant data historian. The DCS has data historical storage and retrieval capabilities in order to facilitate long-term monitoring of plant equipment and performance. This system provides the ability to generate reports and trends of the stored historical data.

\section{ELECTRONICS ROOM}

The electronics room provides housing for the engineering workstations, vibration monitoring system cabinets for the steam turbine, boiler feed pumps and HTF pumps, UPS Power Distribution panels, generator / transformer protection panels, switchyard protective relaying cabinets, DCS control processor and I/O cabinets, STG control system and the DCS networking cabinet.

\subsubsection{Power Block Communications Network}

The DCS data highway is based on a Gigabit Ethernet communications system. The data highway and remote I/O communications are redundant (see Figure $\mathrm{x}$ ). The data highway inside the control room and electronics room utilizes the DCS vendor's standard copper cable for short connections. Fiber optic cables are used for longer routes between buildings and rooms.

\subsubsection{Power Block Instrumentation Requirements}

Redundant measurements are performed for system critical process variables.: The redundant measured variables include: turbine throttle pressure \& temperature, turbine reheat pressure \& temperature, steam generator pressure \& level, feedwater pressure \& temperature, condensate pressure \& temperature, deaerator tank level, condenser pressure, hotwell level, superheater pressure \& temperature, BFP flow, feedwater \& condensate heater level and instrument air header pressure.

The control system processes triple redundant inputs using a median select algorithm be used for control and protection. Dual redundant instruments are averaged. An alarm is generated if the deviation between instruments exceeds a predetermined deadband.

\subsubsection{Solar Field Control System and Equipment}

The solar field control (SFC) system consists of a microprocessor based supervisory control and data acquisition (SCADA) system, and local controllers for each solar collector. All solar field system parameters are monitored, controlled, displayed, alarmed, recorded and trended. The system is based on Windows-compatible work stations and servers for operator interface and 


\title{
WorleyParsons
}

resources \& energy

\author{
NATIONAL RENEWABLE ENERGY LABORATORY \\ CSP PARABOLIC TROUGH PLANT COST ASSESSMENT
}

system engineering functions. The SFC network is seamless with the power block DCS network. All data is shared between networks.

\section{SOLAR FIELD CONTROL SYSTEM}

The SCADA system provides monitoring and high level control of the entire solar field. The SCADA system provides each local controller with master Track, Defocus, Stop, and override control signals. The system monitors the operation and performance of each local controller and associated solar collector and provides process indication and alarms on a central control room display.

A local controller is provided for each solar collector assembly. The controller contains a microprocessor based control system such as a PLC, a variable speed drive / servo valves for actuation of the collector drive system, a network switch and any electrical distribution and protection equipment.

Each local controller operates independently. Once given a master control signal from the SCADA system that initiates the Track mode, the local controller calculates the position of the sun based on its latitude and longitude and the time from the GPS clock and positions the solar collector appropriately.

The local controller monitors the angular position of the collector for accurate closed loop feedback control. Any deviations from the calculated position are alarmed in the control room. A temperature element is installed in the HTF pipe at each solar collector. The local controller monitors this temperature and "defocuses" the positioning of the solar collector to prevent overtemperature conditions.

\section{SOLAR FIELD CONTROL ROOM}

The SCADA operator interface displays are seamless with those provided with the DCS. The control network provides data sharing between the power block and solar field systems. A common control room is provided for the power block and solar field operator displays.

Independent data historical storage and retrieval capabilities are provided for the solar field network in order to facilitate long-term monitoring of the solar field equipment and performance.

\section{Solar Field Communications Network}

The SFC data highway is a based on a star - ring configuration. The network utilizes multi-mode fiber optic cable. To eliminate any potential for disruptive signal noise, no copper communication cables are utilized in the solar field.

The solar field is divided into sectors. Each sector has it own network using a HIPER-ring or turbo-ring design. This design provides an inherent level of redundancy in that if a segment is broken the data signal is transmitted around the ring in both directions.

Each solar field sector is connected to the plant control network using a star configuration. The fiber optic cables forming the star are non-redundant; however, spare fiber is installed in the event that one or more strings are damaged.

\section{SOLAR FIELD INSTRUMENTATION}

A meteorological tower station is included. Each tower is equipped with instrumentation to monitor wind speed, wind direction, normal incident solar radiation, temperature and barometric pressure. Each tower is supplied with power from separate and independent power sources. 


\section{WorleyParsons}

resources \& energy

NATIONAL RENEWABLE ENERGY LABORATORY CSP PARABOLIC TROUGH PLANT COST ASSESSMENT

The instrument signals communicate with the plant control network using a wireless communications system.

\subsection{Civil Sitework Descriptions}

\subsubsection{Roads, Parking, and Fencing}

The reference plant will be accessed from the nearest major intersection in Daggett, CA via an existing public road that has been assumed to be asphalt paved. Due to heavy construction traffic this public road will need to be resurfaced when construction is complete. All existing roadways, intersections, and bridges will need to be evaluated for oversized/heavy haul deliveries. All proposed roadways will be designed for this as well. A proposed asphalt paved entrance road will intersect the existing public road and continue towards the solar field. This entrance road will terminate at a guard house and gated entrance at the northeast corner of the reference solar field. Access will continue along the east side of the solar field and turn west towards the power block on an asphalt paved power block road. A loop road will encompass the perimeter of the power block. The southern half of the power block loop road will be paved with asphalt, while the northern half will be surfaced with gravel. An asphalt surfaced parking lot will be located adjacent to the Warehouse/Maintenance Building and Administration Building within the power block. Refer to figures 17 to 19 below for roadway sections and details.

Figure 17. Typical road section detail for site access and inner power block asphalt roads.

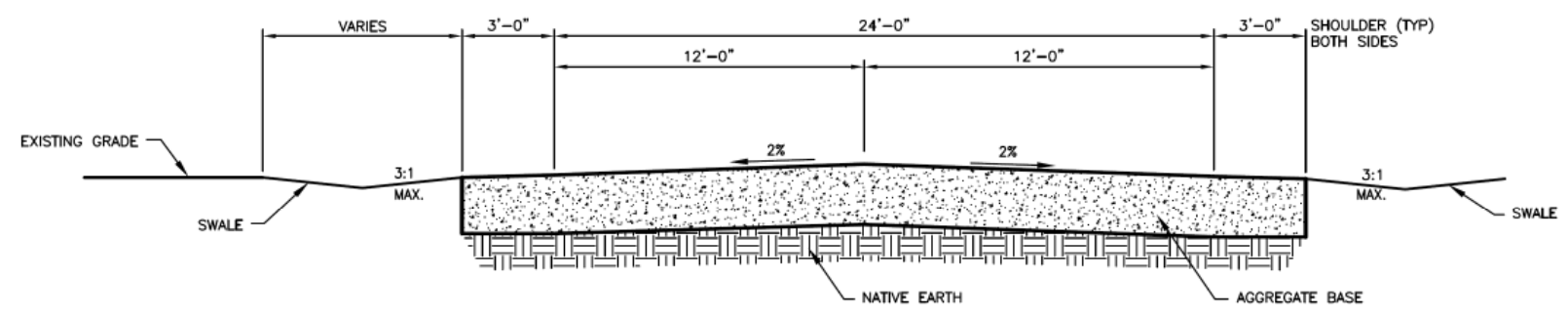




\section{WorleyParsons}

resources \& energy

NATIONAL RENEWABLE ENERGY LABORATORY CSP PARABOLIC TROUGH PLANT COST ASSESSMENT

Figure 18. Typical road section detail for perimeter gravel roads.

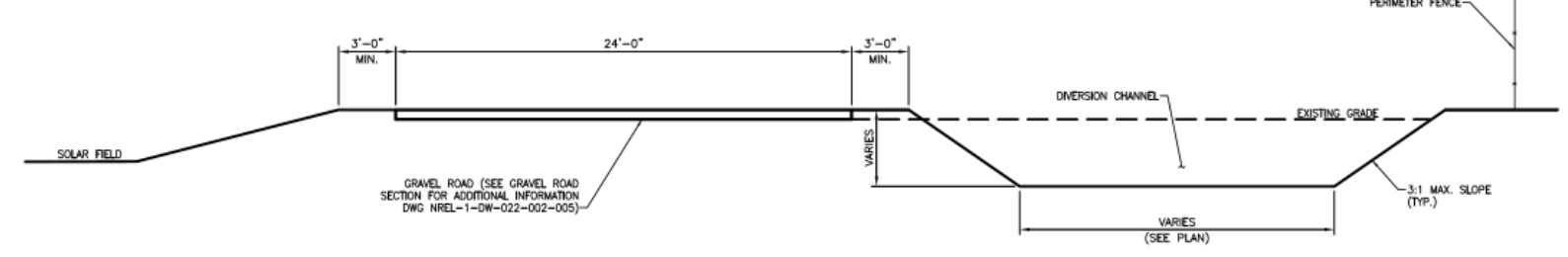

Figure 19. Typical road section detail for gravel roads.

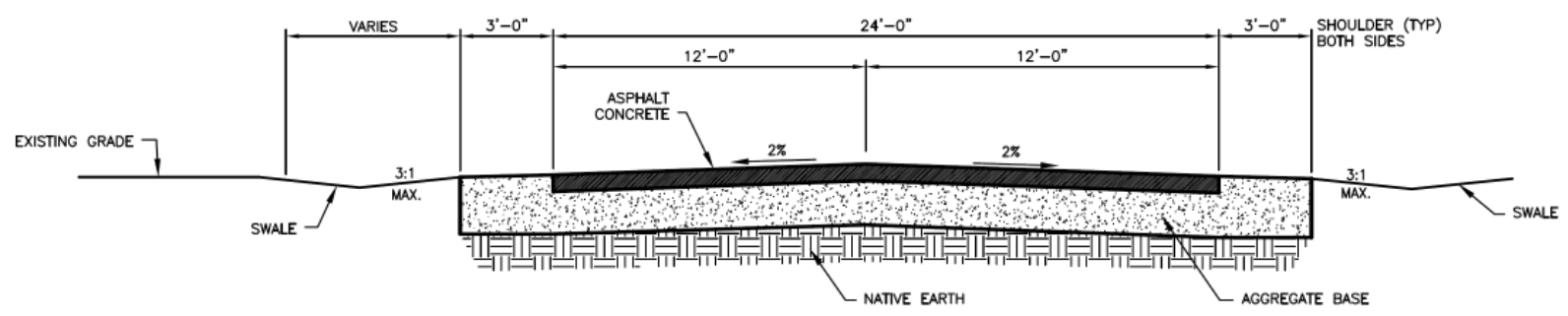

Solar array access roads will be provided between each parabolic trough for mirror washing activities. These solar array roads will consist of proof rolled compacted native soil. A gravel loop road will encompass the perimeter of the solar field. A diversion channel will be located on the upstream side of the gravel solar field loop road to divert offsite watershed runoff around the solar field site. A perimeter security fence will be located just outside of the diversion channel, encompassing the perimeter of the solar field, including the detention and evaporation ponds.

\subsubsection{Bioremediation / Land Farm Area}

A bioremediation/land farm unit will be required to treat non-hazardous soil contaminated from HTF spills. Soil contaminated from HTF spills that test as a Resource Conservation and Recovery Act (RCRA) characteristic waste will be managed as hazardous waste. The bioremediation area will include a concrete-lined shallow basin and a leachate collection and removal system (LCRS).

Treatment in the bioremediation unit will involve the addition of nitrogen and phosphorous (i.e., fertilizers) as nutrients to the HTF-contaminated soil to stimulate consumption of HTF by the native bacteria. The soil will remain in the bioremediation unit until concentrations are reduced sufficiently to allow its re-use as on-site fill material. Soil for reuse would be placed within the fence boundaries to preserve isolation between the adjacent wildlife and habitat and any bioremediated soils.

The land farm area will be located next to the bioremediation area. Soils will be brought to the unlined land farm, mixed with compacted lime treated native soil, and stored there until hazardous concentrations are low enough to be used as fill material on the site. Natural attenuation is the only "treatment" that occurs at the land farm; no additives (e.g., fertilizer, water) would be used. 


\title{
WorleyParsons
}

resources \& energy

\author{
NATIONAL RENEWABLE ENERGY LABORATORY \\ CSP PARABOLIC TROUGH PLANT COST ASSESSMENT
}

\subsubsection{Site Preparation, Earthwork, and Improvements}

Since the topography of the reference plant is unknown, a grading plan to establish earthwork quantities was not performed. One of the main objectives of a site grading plan design is to minimize earthwork movement. A zero balance grading plan is ideal (i.e. no import or export of earthwork) and has been assumed to be achievable for this reference plant. At a minimum 6 inches $(152 \mathrm{~mm})$ to $1 \mathrm{foot}(304.8 \mathrm{~mm})$ of soil will be removed and/or relocated within the site during clearing, grubbing, and grading activities. It has been assumed for this reference plant that 1 foot $(304.8 \mathrm{~mm}$ ) of earthwork (cut/fill) will be moved over the entire solar field site. It has also been assumed that the entire solar field site is covered with desert vegetation (shrubs, etc.). Therefore the entire solar field site will need to be cleared and grubbed prior to rough grading. Prior to beginning any earthwork activities, including clearing and grubbing, site preparation must be performed by strategically placing erosion and sediment control measures (Best Management Practices - BMPs) per the Erosion and Sediment Control Plans and Details. This includes the installation of silt fence, rock check dams, riprap, inlet/outlet protection, gravel construction entrances, construction laydown and stockpiling areas, slope protection/erosion control blankets, etc. There will be two temporary aggregate surfaced construction laydown and parking areas, one for the power block and one for the solar field, located just outside of the power block. Adjacent to the temporary solar field laydown area there will be a temporary solar collector fabrication area. The final surfacing for the power block will be yard aggregate while the final surfacing for the solar field will be native soil.

\subsubsection{Onsite Drainage, Detention, and Evaporation Ponds}

A $1 \%$ to $2 \%$ slope range, in the east-west direction, and $0 \%$ (flat) to $1 \%$ in the north-south direction is ideal for the east to west single-axis sun tracking parabolic trough field in aboveequator regions. It has been assumed that the reference plant's topography will allow for this grading scheme. Ideally, evaporation ponds will be located downstream of the power block to allow for gravitationally fed cooling tower blowdown. Detention ponds will always be located downstream of the natural flow of storm water runoff. Site specific information may require several smaller detention ponds separately located around the perimeter of the field; however, one larger one was assumed for this reference plant.

Figure 20. Typical evaporation pond detail.

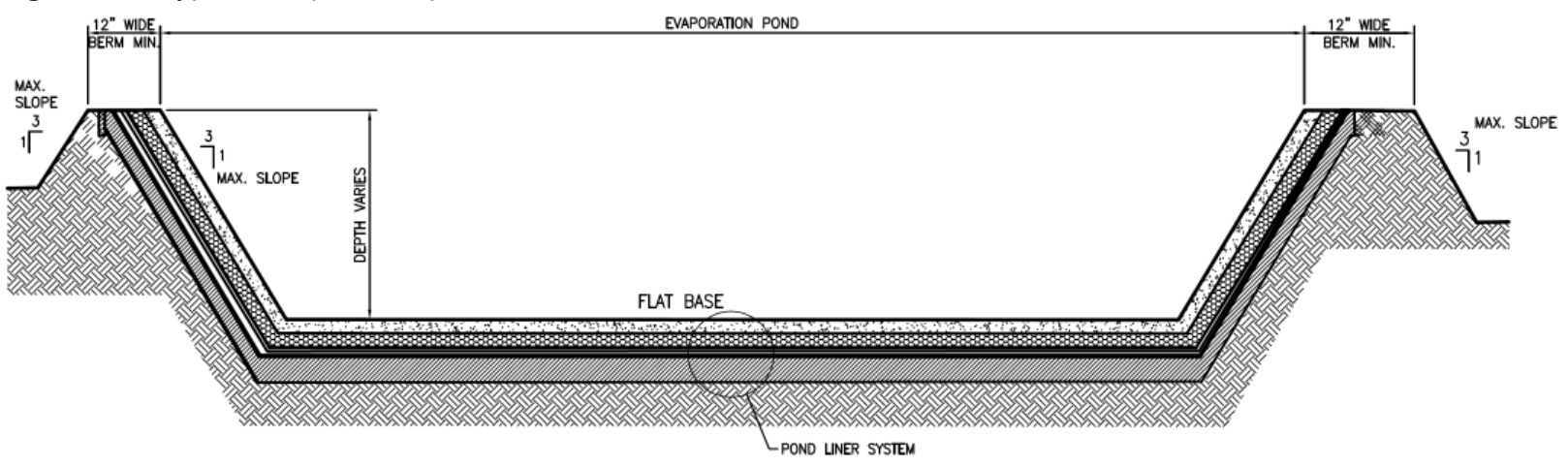




\section{WorleyParsons}

resources \& energy

\section{NATIONAL RENEWABLE ENERGY LABORATORY CSP PARABOLIC TROUGH PLANT COST ASSESSMENT}

The 20 Acre-Ft detention pond will capture the developed major storm event and release the runoff through a concrete outlet structure at the historic rate. The detention pond will also be equipped with an emergency spillway designed to pass the developed major storm event. Existing major drainage washes will be diverted around the solar field site via diversion channels. These diversion channels will return the upstream offsite runoff to their original course on the downstream side of the solar field site.

\subsubsection{Thermal Storage Salt Containment Berm}

An earthen berm will surround the thermal salt storage tanks inside the power block. The berm shall be designed to contain the volume of two salt storage tanks. This is assuming two of the four tanks have a failure at the same time. Access will need to be provided from the power block loop road into the salt storage tank area. This will require concrete surfaced vehicular ramps down into the containment over the berm. These ramps will be located in an area where adequate run out and turning space is provided as the vehicles enter the containment area (i.e. not immediately adjacent to the salt storage tanks). The ramps shall be sloped and laid out to accommodate safe access by all potential maintenance vehicles. At least two ramps will be provided; one ramp for smaller day to day maintenance vehicle access and another ramp for larger semi-trailer and crane access.

Figure 21. Salt storage berm section detail.

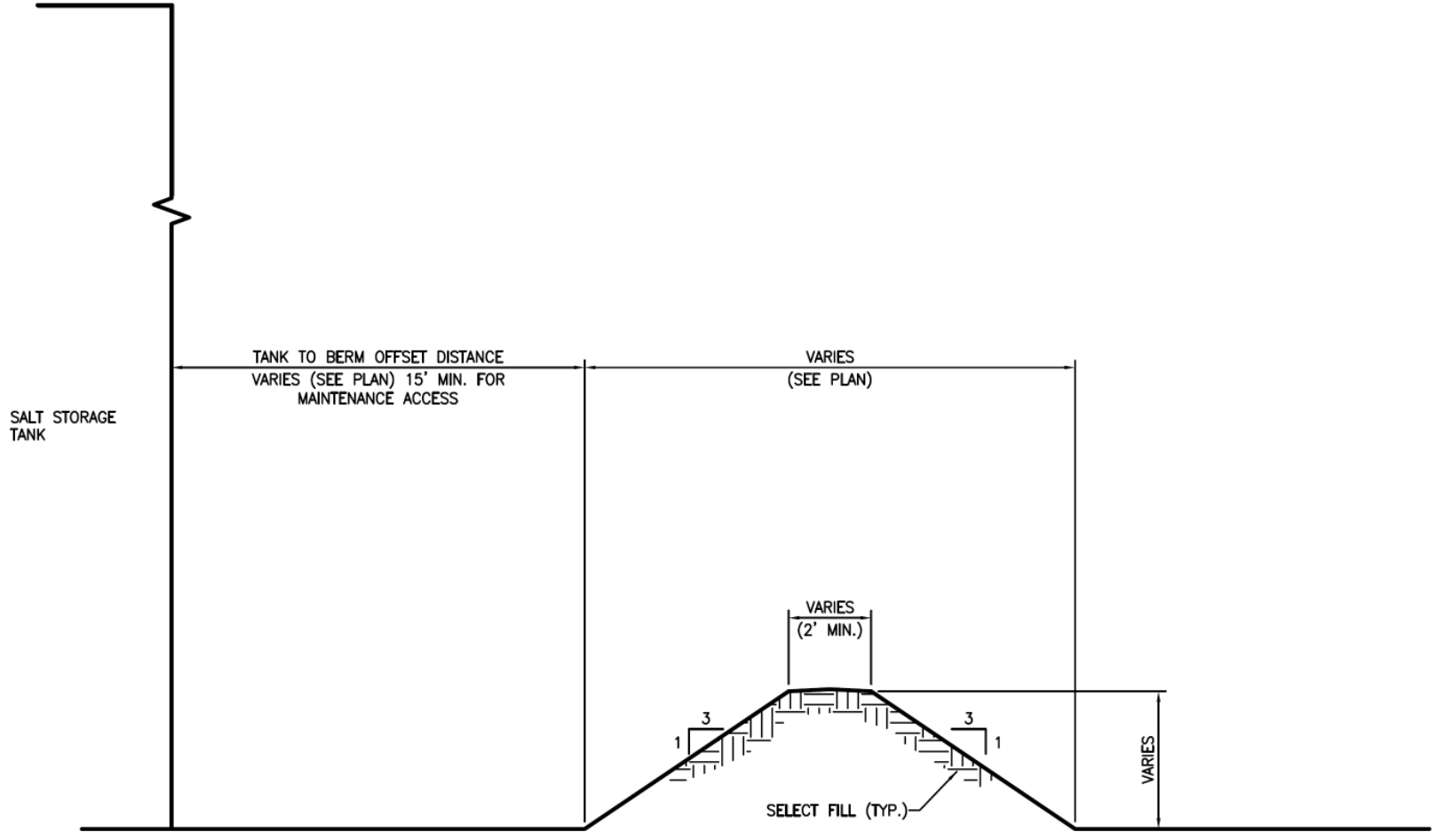




\section{WorleyParsons}

resources \& energy

NATIONAL RENEWABLE ENERGY LABORATORY CSP PARABOLIC TROUGH PLANT COST ASSESSMENT

Figure 22. Salt storage berm maintenance access drive ramp detail.

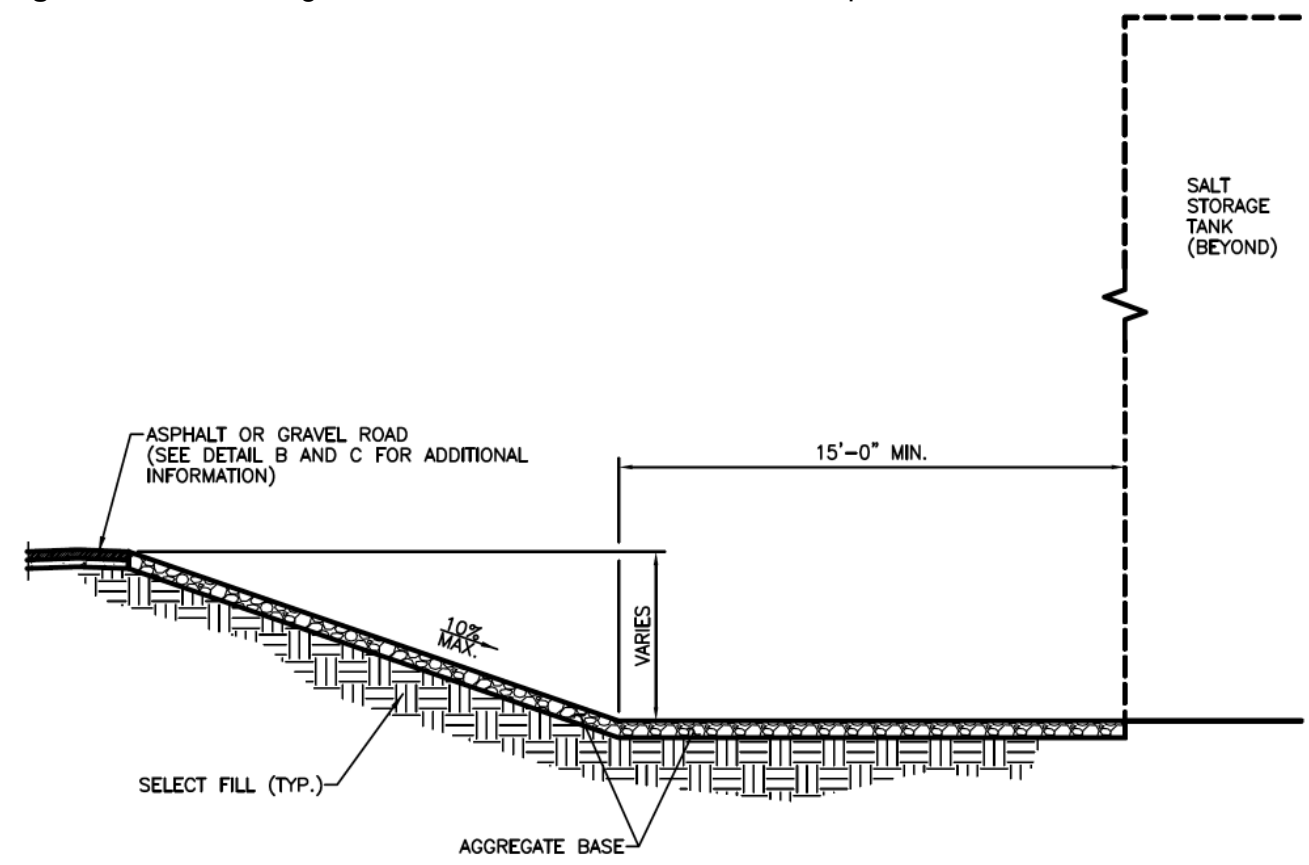

\subsection{Structural Support and Foundation Descriptions}

\subsubsection{Solar Field Structures and Foundations}

Each SCA will be supported by drilled piers (caissons). Not having any soil data, caisson diameter and depth were assumed. The HTF pipe header and SCA loop piping supports will also be supported by drilled caissons. These caissons also have an assumed diameter and depth. The power block will have structural steel pipe racks to support HTF/steam/water pipe, electrical/control cable, and lighting. A larger heavy duty rack will support the HTF headers up until the final reheater vessel, where the rack will transition into a smaller rack to support the lighter steam and water lines. A similar pipe support rack will be needed for HTF header pipe feeding the TES system. 


\section{WorleyParsons}

resources \& energy

NATIONAL RENEWABLE ENERGY LABORATORY CSP PARABOLIC TROUGH PLANT COST ASSESSMENT

Figure 23. Solar collector foundation—normal drive pylon section detail.
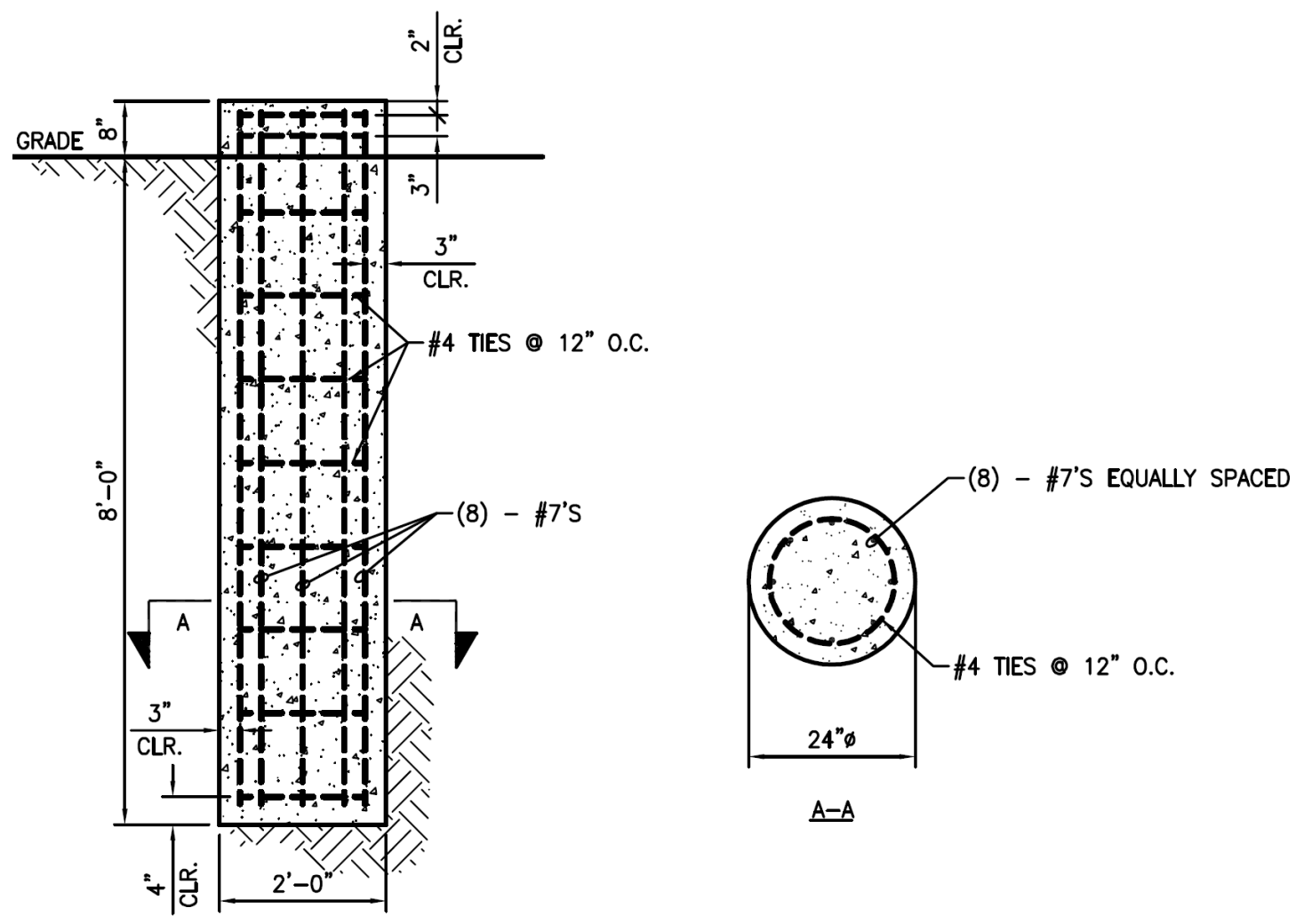


\section{WorleyParsons}

resources \& energy

NATIONAL RENEWABLE ENERGY LABORATORY CSP PARABOLIC TROUGH PLANT COST ASSESSMENT

Figure 23. Solar collector foundation-drive pylon section detail.

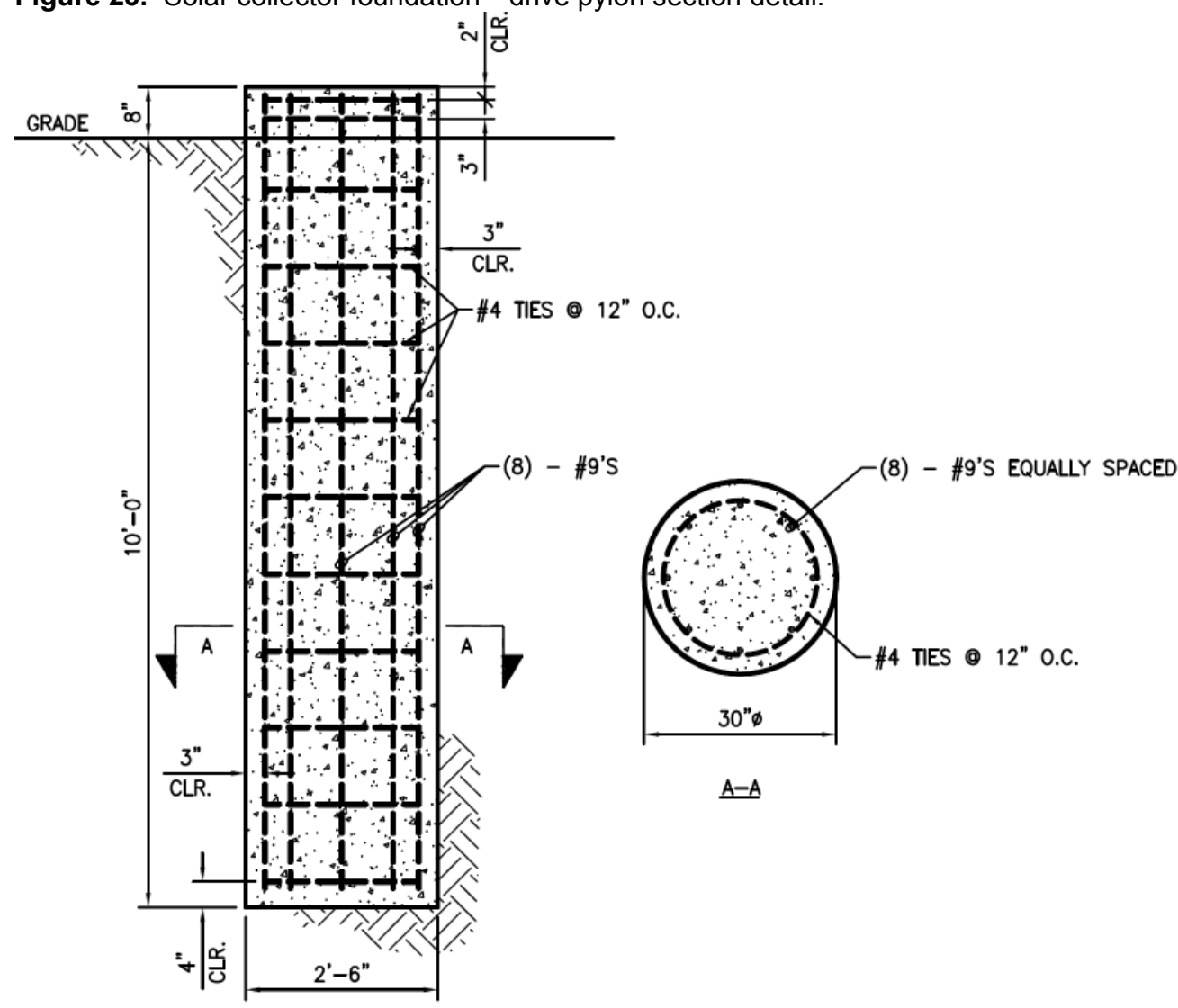

\subsubsection{Power Block Structures and Foundations}

There will be several equipment foundations and containment areas required in the power block area, with the STG concrete foundation supporting the heaviest duty. The HTF Expansion Tank and overflow pumps will share a common concrete foundation system with concrete containment and a local sump for potential HTF leaks/spills. The bulk nitrogen storage and vaporizer will require smaller individual concrete slab foundations. The HTF circulation pumps will require a concrete slab foundation with curbing/containment. The solar steam generator heat exchangers will share a common concrete foundation system with curbing/containment. 


\section{WorleyParsons}

resources \& energy

NATIONAL RENEWABLE ENERGY LABORATORY

CSP PARABOLIC TROUGH PLANT COST ASSESSMENT

\section{COST ESTIMATE BASIS (SUBJECT TO REVISION)}

The estimate is based on an Engineer - Procure - Construction Management (EPCM) approach. Engineering and Design, Construction Management, and Start-up \& Commissioning costs are included.

Material Take-off (MTO) and Design Allowances are included in the estimate and are intended to compensate for the degree of engineering that is incomplete. This is not a contingency; rather it is a minor allowance included to cover the nominal quantity growth which inevitably occurs as the design is further developed.

Contractor mark-up on bulk materials reflects the mark-up that contractors will apply to bulk materials provided under their respective contracts. A rate of $5 \%$ is used for these materials. This has been reduced from the more typical rate of $8 \%$ to account for the "engineered bulks", including most of the piping being supplied by the EPCM contractor and thus not being subject to a mark-up..

The estimate excludes escalation. All costs are presented as overnight 2nd Quarter 2009 dollars.

Project Contingency addresses unforeseen elements of costs within the current defined project scope. It is expected that by the end of the project the entire contingency will be spent on either direct or indirect costs. The contingency is applied as follows, $5 \%$ on equipment, $10 \%$ on bulk material, $10 \%$ on installation labor for the solar field and $15 \%$ on the balance of installation labor, and $0 \%$ on professional services.

\subsection{Quantity Development}

Equipment quantities for major equipment components are based on preliminary engineering provided in drawings, flow diagrams, process and instrumentation diagrams (P\&IDs), equipment lists, and electric one-line diagrams. Major piping networks such as HTF, steam, feedwater, condensate, circ water, and firewater were conceptually laid out and specified on P\&IDs.

Minor balance of plant equipment not included in the project design documents are based on similar plant designs previously developed by WorleyParsons. Examples of minor balance of plant equipment include steam turbine gland steam seal system, condenser air removal system, cooling tower chemical feed system, service air system, steam / water sampling system, and compressed air systems. Bulk material quantities were developed for select major systems based on conceptual routings and sizing where available. Quantities for the balance of plant systems were developed by scaling from a similarly sized plant to meet specific NREL site requirements.

\subsection{Material and Equipment Pricing}

The following equipment costs are based on budgetary quotes:

- Thermal energy storage system (EPC turnkey)

- Steam turbine generator, gland steam condenser, and lube oil skid 


\section{WorleyParsons}

resources \& energy

NATIONAL RENEWABLE ENERGY LABORATORY CSP PARABOLIC TROUGH PLANT COST ASSESSMENT

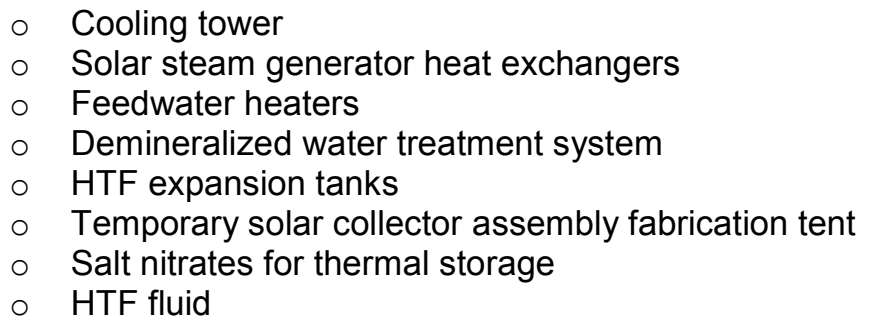

Remaining equipment costs are based on WorleyParsons cost estimating database, adjusted to 2Q2009 dollars. The bulk material costs are based on recent pricing for similar materials from the WorleyParsons estimating database, adjusted to 2Q2009 dollars. Most of the equipment and materials will be transported by truck to the project site.

\subsection{Construction Labor}

Overall construction labor costs include wage rates, installation hours, labor productivity, labor availability and construction indirect costs.

\subsubsection{Wage Rates}

Union shop wage rates are based on the 2009 RS Means Labor Rates for the Construction Industry. Rates are based on Riverside, CA and are valid to 2Q 2009.

As an added level of project cost verification, WorleyParsons performed a cost comparison using Yuma, AZ merit shop craft wage rates as a baseline. It appears that Riverside, CA union wage rates add approximately $38 \%$ to the labor cost component (without the productivity factor), and approximately $56 \%$ when the productivity factor is included.

\subsubsection{Installation Hours}

WorleyParsons maintains a database of standard unit installation hours. The database represents standard installation rates for US Gulf Coast Merit Shop. Equipment setting manhours were developed by evaluating estimated weights, equipment size, and number of components in conjunction with crew sizes and approximated time. Bulk material man-hours are based on standard unit installation rates. The resultant hours are further adjusted for productivity (described below).

\subsubsection{Labor Productivity}

The estimate reflects productivity for the Daggett, CA area. In evaluating productivity, factors such as jobsite location, type of work (i.e. new construction) and site size are considered. Labor productivity factors (multipliers over US Gulf Coast Merit Shop) have been included to reflect anticipated site specific labor productivity. A productivity factor of 1.2 was applied to the USGC labor hours, with the exception of the SCA assembly work performed $\mathrm{n}$ the on-site fabrication 


\section{WorleyParsons}

resources \& energy

NATIONAL RENEWABLE ENERGY LABORATORY CSP PARABOLIC TROUGH PLANT COST ASSESSMENT

structure and the hours associated with salt melting. No productivity adjustment was applied to furnish and erect quotes obtained specifically for this project.

\subsubsection{Labor Availability}

Labor is based on a 50-hour work-week (5-10s). The estimate includes an allowance of $\$ 60 /$ day for travel and per diem. No additional incentives have been included to attract or retain craft labor. The estimate is based on an adequate supply of qualified craft personnel being available to staff this project.

\subsubsection{Construction Indirect Costs}

In addition to base wage rates and fringe benefits, labor costs include construction indirect costs consisting of:

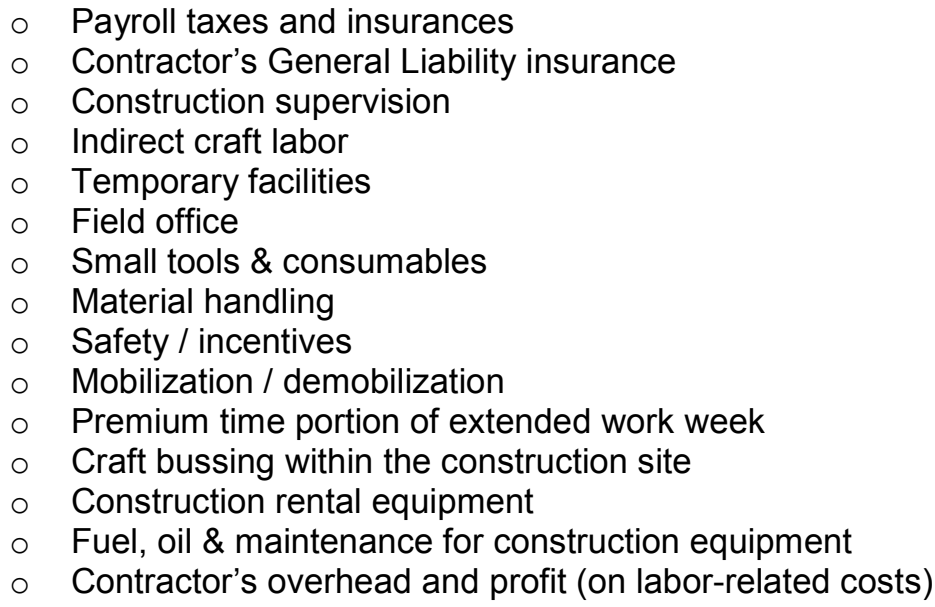

\subsection{Clarifications}

\subsubsection{Civil / Structural}

- The site is relatively flat. No underground obstructions, rock formations, or unusual site conditions exist.

- All grading will be balanced across the site.

- Earthwork (rough grading) is based on $1 \mathrm{ft}$ of earth movement over the entire solar field site.

- Site geography is assumed to have an average slope between $1 \%$ and $2 \%$ and can be graded with conventional equipment.

- Topsoil removal is not required. The topsoil will be scarified and compacted.

- Approximately 1000 acres $\left(4,046,873 \mathrm{~m}^{2}\right)$ of land will be cleared and grubbed. Desert vegetation (shrubs, etc.) covers the entire site.

$\circ$ Dewatering is not required. 


\title{
WorleyParsons
}

resources \& energy

\author{
NATIONAL RENEWABLE ENERGY LABORATORY \\ CSP PARABOLIC TROUGH PLANT COST ASSESSMENT
}

- The power block and access roads will be paved (asphalt or gravel). The solar field roads will be compacted native soil (proof rolled).

- Soil binder/stabilizer is not included for dust control at solar field roads.

- The entire site will be fenced with 8 foot $(2.4 \mathrm{~m})$ high chain link fencing with barbed wire.

- The evaporation ponds will have a single HDPE liner. A leak detection system is not included. (In the process of verifying whether double liner and leak detection is required by California Code)

- The detention pond will be unlined with a compacted native soil bottom.

- The soil under the bio-remediation area will be lime treated.

- Concrete foundations are based on 4000 psi concrete. Piles are not required.

- Concrete foundations are included for all equipment and buildings.

- The steam turbine and ancillary equipment will be outdoors.

- Warehouse \& maintenance, water treatment, administration, and cooling tower chemical feed/storage buildings are included.

- A fabrication tent for the solar array structure assembly is included.

- Sanitary waste will not be piped offsite; rather it will run through a septic tank and run through an onsite leach field.

\subsubsection{Mechanical / Piping}

- Thermal energy storage system is a completely installed, tested and commissioned turnkey EPC cost from a vendor.

- Not having any known land constraints, the solar collector field is laid out in a squareshaped array with a central power block to minimize HTF pumping loads.

- The salt fill will be delivered in one-tonne supersacs. Salt melting equipment and labor are included. Salt blending is not required, therefore, it is excluded.

- Cooling tower blowdown will be discharged to three on-site evaporation ponds.

- Cooling tower makeup will be gravity fed from the adjacent raw/fire/CT makeup storage tank.

- Stress relieving for piping is included as required by code.

- Expansion loops for the HTF piping are included.

- Water supply will be provided by three water wells. Electric well pump power is not included in the plant's auxiliary power load and will be purchased directly from the utility having jurisdiction.

- No water quality information is known and therefore no pre or post water treatment is included.

- A natural gas pipeline with adequate pressure and allowed permission is assumed within reasonable proximity for plant interconnection (i.e. no onsite natural gas compression or propane storage is needed).

- SCA costs are built bottoms up from individual component costs (mirror, structure, receiver).

- An empirical sun-tracker using a shadowed PV plate concept is included on all SCAs. These are typically not needed if the drives have pre-programmed tracking logic built-in. The empirical tracker is included for redundancy per NREL's direction.

- No wind fence is included in the estimate.

- No fire protection equipment is included in the solar field. Only power block equipment is protected. 


\section{WorleyParsons}

resources \& energy

\section{NATIONAL RENEWABLE ENERGY LABORATORY CSP PARABOLIC TROUGH PLANT COST ASSESSMENT}

- Underground steel pipe is coated and wrapped.

\subsubsection{Electrical / Instrumentation}

- A $13.8 \mathrm{kV}-230 \mathrm{kV}$ generator step-up transformer is included.

- An on-site switchyard with 230kV main circuit breaker and main disconnect switches are included.

- No transmission lines beyond the switchyard are included.

- The estimate includes auxiliary transformers, station service transformers, and solar field transformers.

- SCA drive power converters are included.

- PDC buildings and equipment are included.

- Underground duct bank is included.

- Cathodic protection is included for underground piping.

\subsubsection{Other}

- Engineering work assumes that the selected site is void of all fatal-flaws which could significantly impact project cost and schedule. These flaws include, but are not limited to: habitat and locations of threatened-endangered and sensitive species, abundance of other protected (e.g., native) species, distribution of noxious weeds, areas of critical wildlife habitats and movement corridors, contaminated soil or hazardous materials, archaeological artefacts, distribution and significance of cultural resources, Native American Tribal concerns, recreational areas, special land use designations (e.g., BLM Areas of Environmental Concern), and others.

- Utility transmissions such as natural gas and supply water are included (excluding electric transmission) up to 200 feet off the furthest site boundary

\subsection{Exclusions}

As discussed above, the scope of the estimates is generally limited to scope within the project fence. A list of items excluded from the estimate is as follows:

- Demolition and removal of existing structures

Import duties \& tariffs

Extraordinary noise mitigation or attenuation

Owner's Costs

Allowance for funds used during construction

All taxes with the exception of payroll taxes

All offsite infrastructure costs

Upgrades to existing rail spur to accommodate delivery of large equipment

Temporary housing and facilities for the construction workers 


\section{WorleyParsons}

resources \& energy

NATIONAL RENEWABLE ENERGY LABORATORY CSP PARABOLIC TROUGH PLANT COST ASSESSMENT

\subsubsection{Typical Owner's Costs}

Owner's costs are excluded from the estimate. Typical Owner's costs include, but are not limited to, the following:

- Permits \& Licensing

- Land Acquisition / Rights of Way Costs

- Economic Development

- Project Development Costs (Geotechnical Investigation \& Site Survey)

- Legal Fees

- Owner's Engineering / Project \& Construction Management Staff

- Plant Operators during start-up

- Electricity consumed during start-up

- Fuel and Reagent consumed during start-up

- Initial Fuel \& Reagent Inventory

- Transmission Interconnections \& Upgrades

- Operating Spare Parts

- Financing Costs 


\section{WorleyParsons}

resources \& energy

\section{APPENDIX A}

\section{Capital Cost Estimate Summary}


ESTIMATE SUMMARY

(Using Riverside, CA union labor rates)

NREL Task 1 Parabolic Trough Cost Assessment

$103 \mathrm{MW}$ net with $6.3 \mathrm{hrs}$ Thermal Storage

9/4/2009

Revision 1

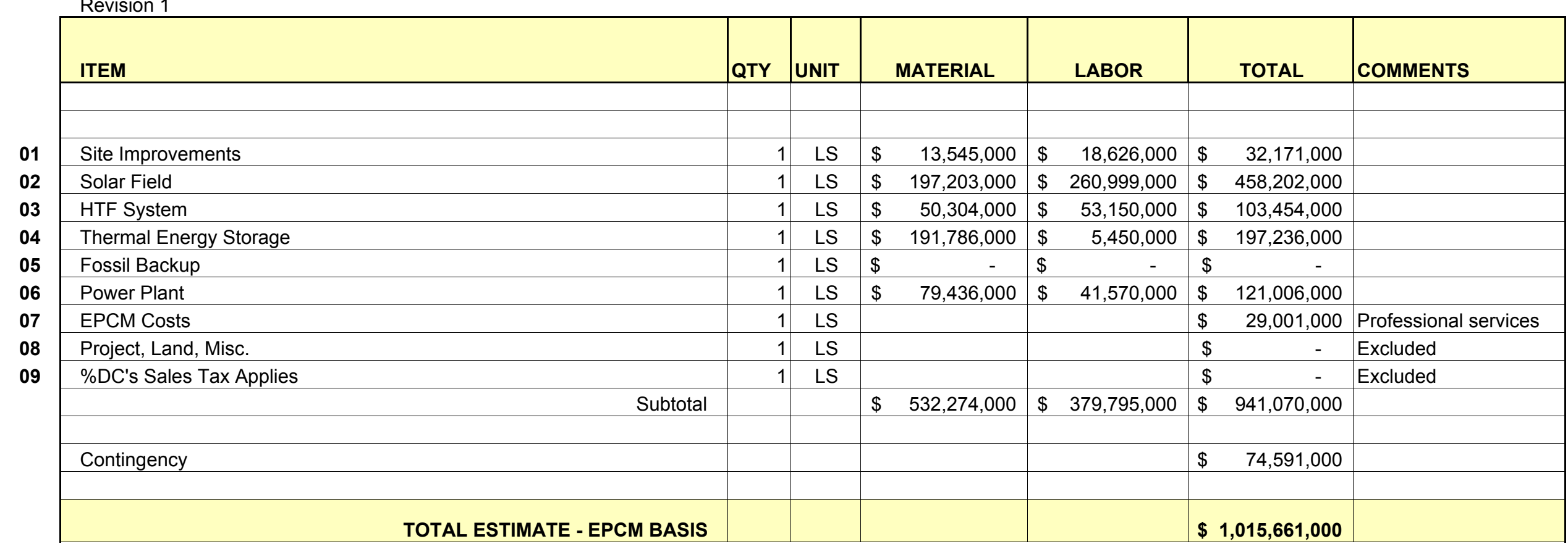

\$ 2,198 per MWe-hr

\$ 9,861 per KW

\section{CRITICAL NOTES}

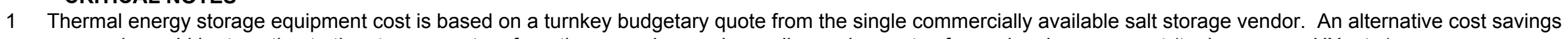
approach would be to estimate the storage system from the ground up and compile vendor quotes for each sub-component (tanks, pumps, HX, etc.)

2 NREL has selected a 2.0 solar multiple. The solar multiple has a significant capital cost impact and is subject to the project developer's financial model.

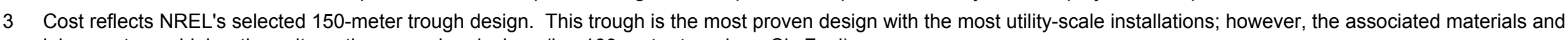
labor costs are higher than alternative emerging designs (i.e. 100-meter trough, or SkyFuel)

4 Labor rates are union-based for Riverside, California with a productivity factor of 1.2. Alternatively, merit-shop based labor rates can significantly reduce costs. 


\section{WorleyParsons}

resources \& energy

\section{APPENDIX B}

\section{O\&M COST Estimate SUMmaRY}




\section{Wil WorleyParsons}

resources \& energy

Project Name: $\quad$ CSP Trough Plant Cooling Study

Project Desc: $\quad$ 103MW net w/ 6.3 hrs TES - Wet Cooled

Location: Daggett, CA

Client: National Renewable Energy Laboratory

Date: $\quad 11 / 05 / 09$

Revision:

Originator:

B

Reviewer:

D. Ross

G. Aron

Model Inputs

\begin{tabular}{|ll|l|}
\hline Est Gas Cost & $\$ / \mathrm{MMBtu}$ & $\$ 6.00$ \\
\hline Est Water Cost & $\$ / \mathrm{acre}-\mathrm{ft}$ & $\$ 450$ \\
\hline Est Auxiliary Power Cost & $\$ / \mathrm{kWh}$ & $\$ 0.08$ \\
\hline
\end{tabular}

Field Design

\begin{tabular}{|ll|l|}
\hline Solar Field Effective Mirror Aperture Area & $\mathrm{m}^{2}$ & 987,540 \\
\hline Net Plant Output to Grid & MWe & 103 \\
\hline Annual Net Power Generation & MWe-hr & 426,717 \\
\hline Total Installed Capital Cost & $\$$ & $\$ 1,015,661,000$ \\
\hline
\end{tabular}

O\&M Cost Breakdown

\begin{tabular}{|l|l|}
\hline Onsite Staff & $\$ 5,283,900$ \\
\hline Utilities & $\$ 296,240$ \\
\hline Purchased Auxiliary Electricity & $\$ 53,400$ \\
\hline Natural Gas & $\$ 558,450$ \\
\hline Water & $\$ 935,333$ \\
\hline Utilities Sub-Total & $\$ 1,031,043$ \\
\hline Consumables & $\$ 903,751$ \\
\hline Maintenance \& Repairs & $\$ 278,298$ \\
\hline Solar Field & $\$ 338,000$ \\
\hline HTF System & $\$ 2,071,188$ \\
\hline TES System & $\$ 3,698,974$ \\
\hline Power Block & $\$ 145,119$ \\
\hline Maintenance \& Repairs Sub-Total & $\$ 105,464$ \\
\hline Chemicals \& Water Treatment & $\$ 81,242$ \\
\hline Office \& Administration & $\$ 377,308$ \\
\hline Training & $\$ 110,203$ \\
\hline Contract Services & \multicolumn{1}{|l|}{} \\
\hline Miscellaneous Cost & $\$ 11,768,584$ \\
\hline $\begin{array}{l}\text { Total Annual O\&M Cost } \\
\text { O\&M Percent of Total Installed Capital Cost }\end{array}$ \\
\hline
\end{tabular}

NOTES

1 Fixed and variable costs are based on 2nd quarter 2009 US $\$$ projected to 2012 first operating year.

2 Water consumption estimates are based on the analysis performed under this task.

3 Raw and waste water assume no pre or post water treatment, respectively.

4 Maintenance and repairs includes spare parts and labor.

5 Solar collector mirror washing is sub-contracted from June through Sept. Mirror washing is performed by plant staff for the remaining months

6 Miscellaneous costs are $2.5 \%$ of maintenance/repairs, chemicals/water treatment, office/administration, training, and contract services. 
Appendices to NREL TP-47605,

Parabolic Trough Reference Plant for Cost Modeling with the Solar Advisor Model; C. Turchi

Appendix B

CSP Parabolic Trough Plant Cost Assessment

Dry-Cooling Option

WorleyParsons Group

Report under NREL contract KAXL-9-99205-01

December 14, 2009 


\section{Dry Cooling Option}

\section{ADDENDUM TO: \\ CSP Parabolic Trough Plant Cost Assessment}

59002501 - NREL-0-LS-019-0002

REVISION B

14DEC2009

WorleyParsons Group

Americas, Northwest Region

Denver Office

1687 Cole Blvd,

Suite 300,

Golden, CO, 80401, USA

Tel: +1 3039284226

Fax: +1 3039284230 
NATIONAL RENEWABLE ENERGY LABORATORY

DRY COOLING OPTION

ADDENDUM TO: CSP PARABOLIC TROUGH PLANT COST ASSESSMENT

\section{Disclaimer}

This report has been prepared for the National Renewable Energy Laboratory, and is subject to and issued in accordance with the agreement between National Renewable Energy Laboratory and WorleyParsons Group, Inc. WorleyParsons Group Inc. accepts no liability or responsibility whatsoever for it in respect of any use of or reliance upon this report by any third party.

\begin{tabular}{|c|c|c|c|c|c|c|c|}
\hline \multicolumn{8}{|c|}{ PROJECT 59002501 - } \\
\hline REV & DESCRIPTION & ORIG & REVIEW & $\begin{array}{l}\text { WORLEY- } \\
\text { PARSONS } \\
\text { APPROVAL }\end{array}$ & DATE & $\begin{array}{l}\text { CLIENT } \\
\text { APPROVAL }\end{array}$ & DATE \\
\hline \multirow[t]{2}{*}{ B } & Issued for Final & $\underline{D R}$ & RB & GMA & $12-14-09$ & $\mathrm{~N} / \mathrm{A}$ & \\
\hline & & D.Ross & R.Bowers & G.Aron & & & \\
\hline & & & & & & & \\
\hline & & & & & & & \\
\hline & & & & & & & \\
\hline
\end{tabular}




\section{TABLE OF CONTENTS}

1. SUMMARY

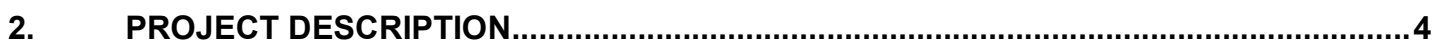

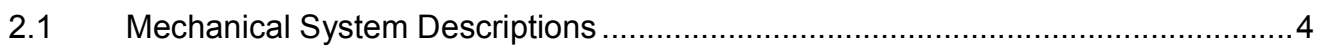

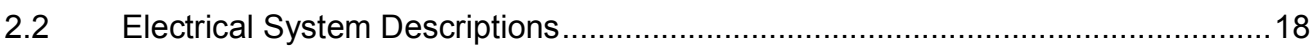

$2.3 \quad$ Instrumentation and Control System Descriptions ............................................22

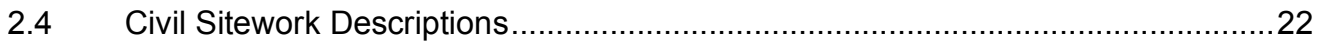

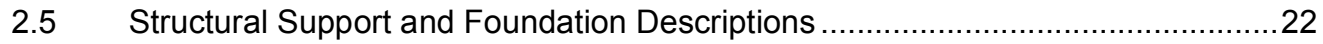

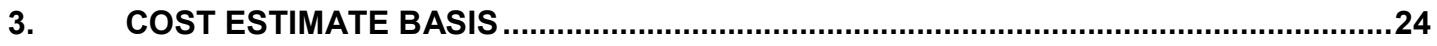

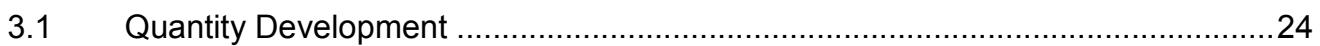

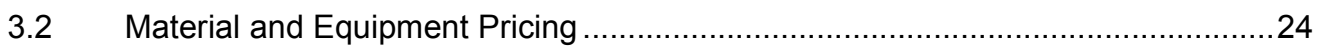

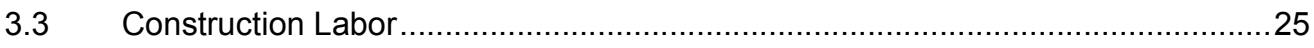

3.4 Clarifications

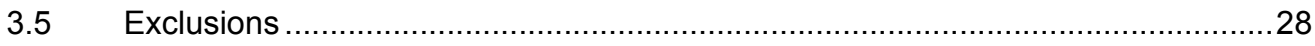

\section{APPENDICES}

Appendix A - Capital Cost Estimate Summary

Appendix B - O\&M Cost Estimate Summary 


\section{LIST OF ACRONYMES}

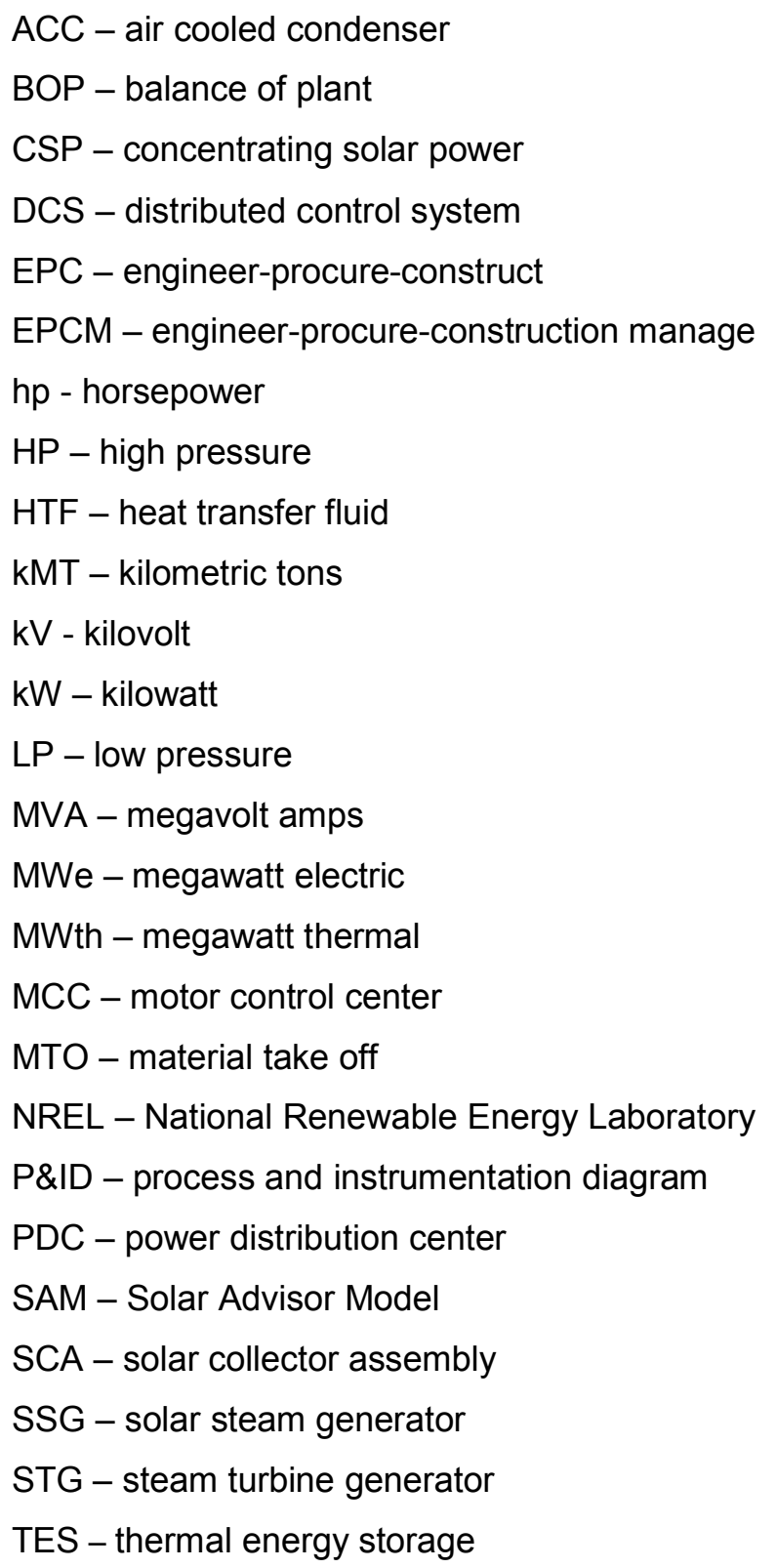

\section{LIST OF TABLES AND FIGURES}

Figure 1 - Power block general arrangement sketch

Figure 2 - Solar field general arrangement sketch

Figure 3 - Process flow diagram

Figure 4 - Water balance, design case

Figure 5 - Water balance, annual average case 
Figure 6 - Water balance, winter average case

Figure 7 - Electrical one-line diagram, Sheet 1

Figure 8 - Electrical one-line diagram, Sheet 2

Table 1 - Major mechanical equipment additions to base case

Table 2 - Major mechanical equipment deletions from base case

Table 3 - Heat balance output summary

Table 4 - Major electrical equipment modifications to base case 


\section{WorleyParsons}

resources \& energy

DRY COOLING OPTION

NATIONAL RENEWABLE ENERGY LABORATORY

ADDENDUM TO: CSP PARABOLIC TROUGH PLANT COST ASSESSMENT

\section{SUMMARY}

The purpose of this alternative design, which utilizes an air cooled condenser (ACC) in lieu of a wet cooling tower, is to provide the solar power industry with an alternative to the wet cooled plant (also referred to as "base case"). The majority of solar power plants will be located in geographical regions that have previously adjudicated water or where water is scarce and/or poor quality.

This report acts as an addendum to the formerly issued "CSP Parabolic Trough Plant Cost Assessment" (also referred to as "base report"). which presented a complete description and cost estimate summary for a 103MWe wet cooled parabolic trough plant with 6.3 hours of thermal energy storage (TES). This report only covers the changes to the base case design and identifies all constants between the two. The cost summary presented herein, however, is the same level of detail as provided in the base report. The National Renewable Energy Laboratory (NREL) intends to update the cost output portion of their Solar Advisor Model (SAM) using the results of this study. All costs found by this study are based on a conceptual engineering effort prepared at a high-level, consistent with the intended purpose and confidence of a Level $2(+/-30 \%)$ cost estimate.

The alternative dry cooled case will hold plant net power to the grid (103MWe) and available TES hours of dispatch $(6.3 \mathrm{hrs})$ at design conditions (i.e. TES, heat transfer fluid, Rankine cycle, and supporting systems operating simultaneously at full load). To achieve the same net output as the wet cooled plant, the steam turbine generator (STG) must now generate $120.5 \mathrm{MWe}$ due to the increase in plant parasitic power. The dry cooled plant requires an additional 6 acres $\left(24,281 \mathrm{~m}^{2}\right)$ or approximately 1024 acres $\left(4,143,998 \mathrm{~m}^{2}\right)$ altogether. The solar collector field and power block areas increased by a combined 58 acres $\left(234,718 \mathrm{~m}^{2}\right)$ and the evaporation ponds decreased by 52 acres $\left(210,437 \mathrm{~m}^{2}\right)$, resulting in the net overall footprint increase. Reference site characteristics remain constant from the base plant design. The primary advantage of dry cooling is water savings. Based on the findings of this study and the base case, dry cooling can save over 13 times the annual water consumption over wet cooling, provided the assumptions effecting water consumption are in place.

As in the wet cooled baseline work, this study should be viewed as a high-level assessment with the understanding that site specific information along with more research, optimization, detailed engineering and capital cost estimating is required in order to arrive at an optimal concentrating solar power (CSP) parabolic trough plant design that meets the Owner's needs. Owner's costs (i.e. land, permitting, Owner's engineer, risk, loan interest etc.) are excluded from this estimate and will be defined as a user input in SAM.

Total installed capital cost for the dry cooled option is $\$ 1.097$ billion with a $+/-30 \%$ confidence, an increase of roughly $\$ 81$ million from the wet cooled plant base design. Annual operation and maintenance costs are $\$ 11.8$ million (1.07\% of total installed cost). The plant is designed with an expected life of 30 years with daily startup and shutdown cycling. Refer to Appendix $A$ and $B$ for further cost details. 


\section{WorleyParsons}

resources \& energy

DRY COOLING OPTION

NATIONAL RENEWABLE ENERGY LABORATORY

ADDENDUM TO: CSP PARABOLIC TROUGH PLANT COST ASSESSMENT

\section{PROJECT DESCRIPTION}

All included subsections provide a brief description of the major cost elements impacted by the change in cooling methods. Description of the cost estimating process is discussed later in Section 3. The same site characteristics and ambient conditions discussed in Section 2 of the base report are also used in designing the dry cooled plant.

\subsection{Mechanical System Descriptions}

The established design approach of holding net output and thermal storage dispatch capacity requires significant equipment and bulk commodity changes to the wet cooled plant in all thermal systems discussed in the base report. Rankine cycle (also referred to as "steam cycle") and balance of plant (BOP) systems involve new types of cooling equipment for steam condensation and auxiliary cooling. In the Rankine cycle, the air cooled condenser replaces the circulating water system and steam surface condenser. Although the dry cooled plant design has less cooling equipment items, the conceptual power block layout (Figure 1) utilizes over 3 acres $\left(12,140 \mathrm{~m}^{2}\right)$ of additional power block area to accommodate the large ACC. A wet cooled plant condenses the turbine exhaust steam on the surface condenser tubes, which reject this heat to the circulating water system to atmosphere via evaporation in the cooling tower. Because water has a much higher heat transfer coefficient $\left(\mathrm{W} / \mathrm{m}^{2}\right.$ ${ }^{\circ} \mathrm{K}$ ) than air, forced convective heat transfer with water allows for a much smaller heat transfer surface area and therefore a smaller condenser is needed. The ACC requires significantly more air flow than the wet cooling tower; consequently its fans consume more plant auxiliary power than the wet cooling tower fans and circulating water pumps combined. On the whole, the dry cooled plant design point auxiliary load is $17.6 \mathrm{MWe}$, approximately $2.6 \mathrm{MWe}$ greater than the wet cooled plant. As a result, a larger steam turbine generator is necessary to maintain the net power output to the grid provided by the base case.

Furthermore, wet cooled plant heat rejection is evaporative and is governed by ambient wet bulb temperature. Dry cooled plant heat rejection is sensible and governed by ambient dry bulb temperature, which is always higher than the wet bulb, and thus the achievable turbine back pressure is always higher with dry cooling than wet cooling. Consequently, the design point Rankine cycle efficiency drops from $37.4 \%$ (wet) to $35.4 \%$ (dry), further increasing the required heat input to maintain 103MWe net capacity.

The increase in steam cycle heat input constitutes an increase in the solar thermal collection field and heat transfer fluid (HTF) system. The thermal energy storage system also grows in capacity (from 1988MWth-hrs to 2144MWth-hrs) due to the decline in steam cycle efficiency. Unlike added/deleted equipment to the Rankine and BOP systems, all three aforementioned systems maintain the same types of equipment. These changes are further discussed later in this section.

A brief description of the major mechanical changes from the wet cooled base design to the dry cooled option is discussed throughout this section. The tables below list the major mechanical equipment added to and deleted from the base wet cooled plant, which constitutes the dry cooled option. All major mechanical equipment listed in Table 4 of the base report, but not shown here, are included in the dry cooled plant design. Mechanical equipment size and configuration modifications to common wet/dry plant designs are discussed later in this section.

Bulk mechanical components such as valves, piping, fasteners, etc. are not listed, but are included in the cost estimate. Further supporting sketches, flow diagrams, lists, tables, and figures are provided to better illustrate the design basis of the cost estimate. Other significant cost items impacted by the 


\section{WorleyParsons}

resources \& energy

DRY COOLING OPTION

NATIONAL RENEWABLE ENERGY LABORATORY

ADDENDUM TO: CSP PARABOLIC TROUGH PLANT COST ASSESSMENT

dry cooling design include civil, structural, electrical, and controls; also discussed later in this addendum.

Table 1. Dry cooled plant major mechanical equipment additions to the base wet cooled plant.

\begin{tabular}{|l|l|}
\hline Equipment Name & Qty \\
\hline Air Cooled Condenser & $1 \times 100 \%$ \\
\hline Condensate Tank & $1 \times 100 \%$ \\
\hline Wet Surface Air Cooler (WSAC) - Aux Cooling & $1 \times 100 \%$ \\
\hline Air Cooled Heat Exchanger (Fin-Fan Cooler) - Aux Cooling & $1 \times 100 \%$ \\
\hline Wastewater Sump Blowdown Booster (to evap ponds) & $2 \times 100 \%$ \\
\hline WSAC Makeup Tank (field erected) & $1 \times 100 \%$ \\
\hline WSAC Chemical Feed/Storage System** & Lot \\
\hline${ }_{* *}^{*}$ No designated enclosure is necessary. Equipment will be located in the water treatment building adjacent to the WSAC.
\end{tabular}

Table 2. Dry cooled plant major mechanical equipment deletions from the base wet cooled plant.

\begin{tabular}{|l|l|}
\hline Equipment Name & Qty \\
\hline Cooling Tower & $1 \times 100 \%$ \\
\hline Steam Surface Condenser & $1 \times 100 \%$ \\
\hline Closed Cooling Water Heat Exchangers & $2 \times 100 \%$ \\
\hline Circulating Water Pumps & $2 \times 100 \%$ \\
\hline Aux Cooling Water (backup/startup) & $1 \times 100 \%$ \\
\hline Cooling Tower Blowdown Booster Pumps (circ water header to evap ponds) & $2 \times 100 \%$ \\
\hline Cooling Tower Chemical Feed/Storage Enclosure & 1 \\
\hline
\end{tabular}

Figure 1 below represents a conceptual layout of the major equipment within the power block for the dry cooled option. Equipment sizes are based on vendor information, past project archives, or engineering judgment/estimates. Equipment arrangement aims to provide a functional layout which meets plant operation and maintenance needs. 


\section{WW WorleyParsons}

resources \& energy

\section{DRY COOLING OPTION}

NATIONAL RENEWABLE ENERGY LABORATORY

ADDENDUM TO: CSP PARABOLIC TROUGH PLANT COST ASSESSMENT

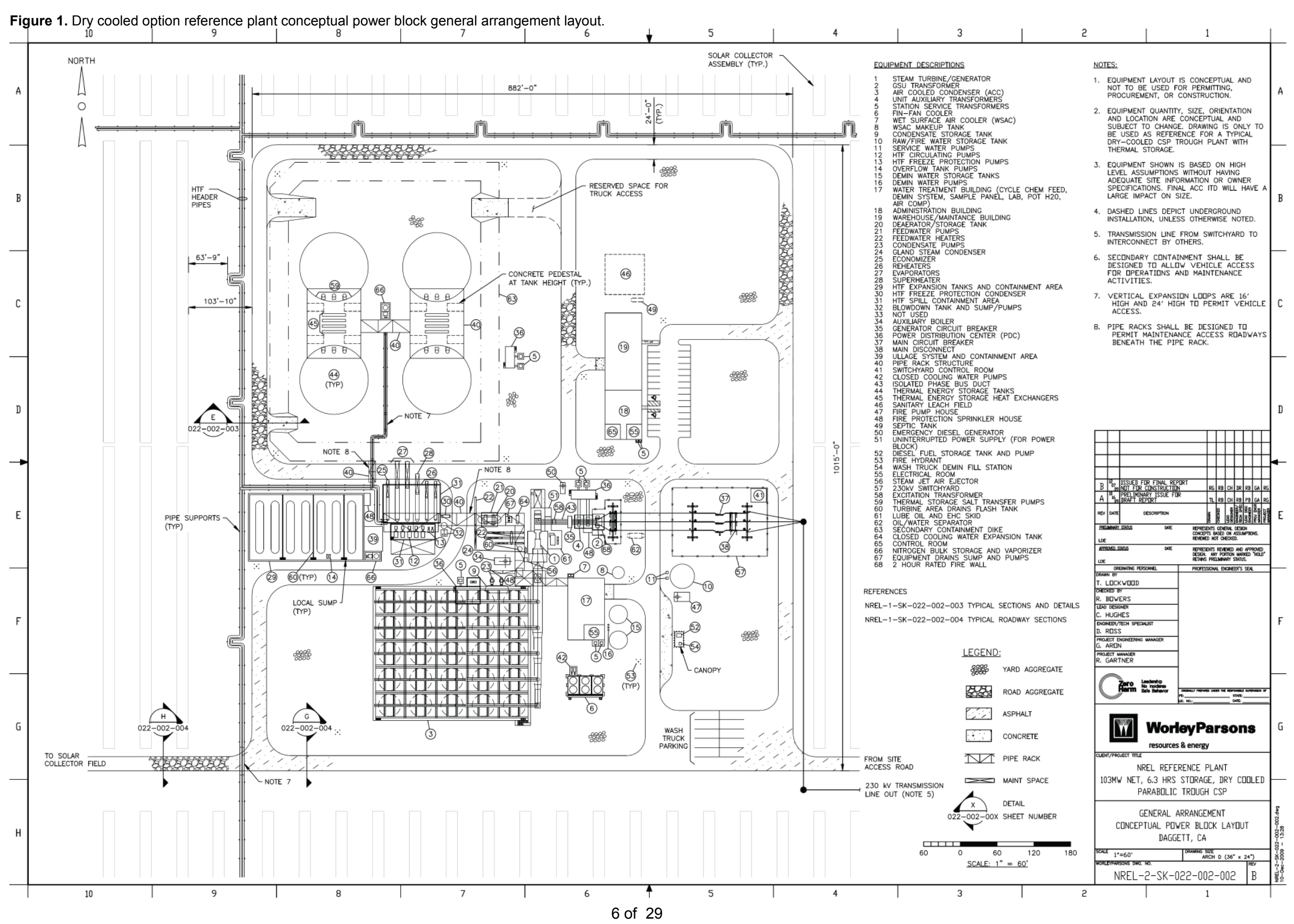




\section{WorleyParsons}

resources \& energy

DRY COOLING OPTION

NATIONAL RENEWABLE ENERGY LABORATORY

ADDENDUM TO: CSP PARABOLIC TROUGH PLANT COST ASSESSMENT

\subsubsection{Solar Thermal Collection Field}

The less-efficient dry cooled Rankine cycle requires more heat input from the solar field than needed in the wet cooled design to maintain net power to the grid. Additionally, the dry cooled plant auxiliary power requirements are greater, which increases design STG output over the base case. The combination of these conditions requires a larger solar collector field. Specifically, the dry cooled plant requires 92 additional solar collector assemblies (SCA) which translates to 23 additional collector loops having 4 SCAs per loop. The same collector type and configuration assumed in the base design is used in the dry cooling option design.

In total, the dry cooled option solar field has $1,062,750 \mathrm{~m}^{2}$ of effective aperture mirror area which can simultaneously and independently provide energy to the steam cycle and TES system via a common HTF system. The solar field size assumes a solar multiple of 2.0, which was independently optimized by NREL specifically for this reference plant. Both wet and dry plants maintain the same solar multiple.

Additional collectors constitute additional commodities such as grading, roadwork, fencing, piping, insulation, pipe supports, cable, control input/output contacts, and other additions or modifications to the base design. These additional commodities are included in the cost estimate. 


\section{Will WorleyParsons}

resources \& energy

\section{DRY COOLING OPTION}

NATIONAL RENEWABLE ENERGY LABORATORY

ADDENDUM TO: CSP PARABOLIC TROUGH PLANT COST ASSESSMENT

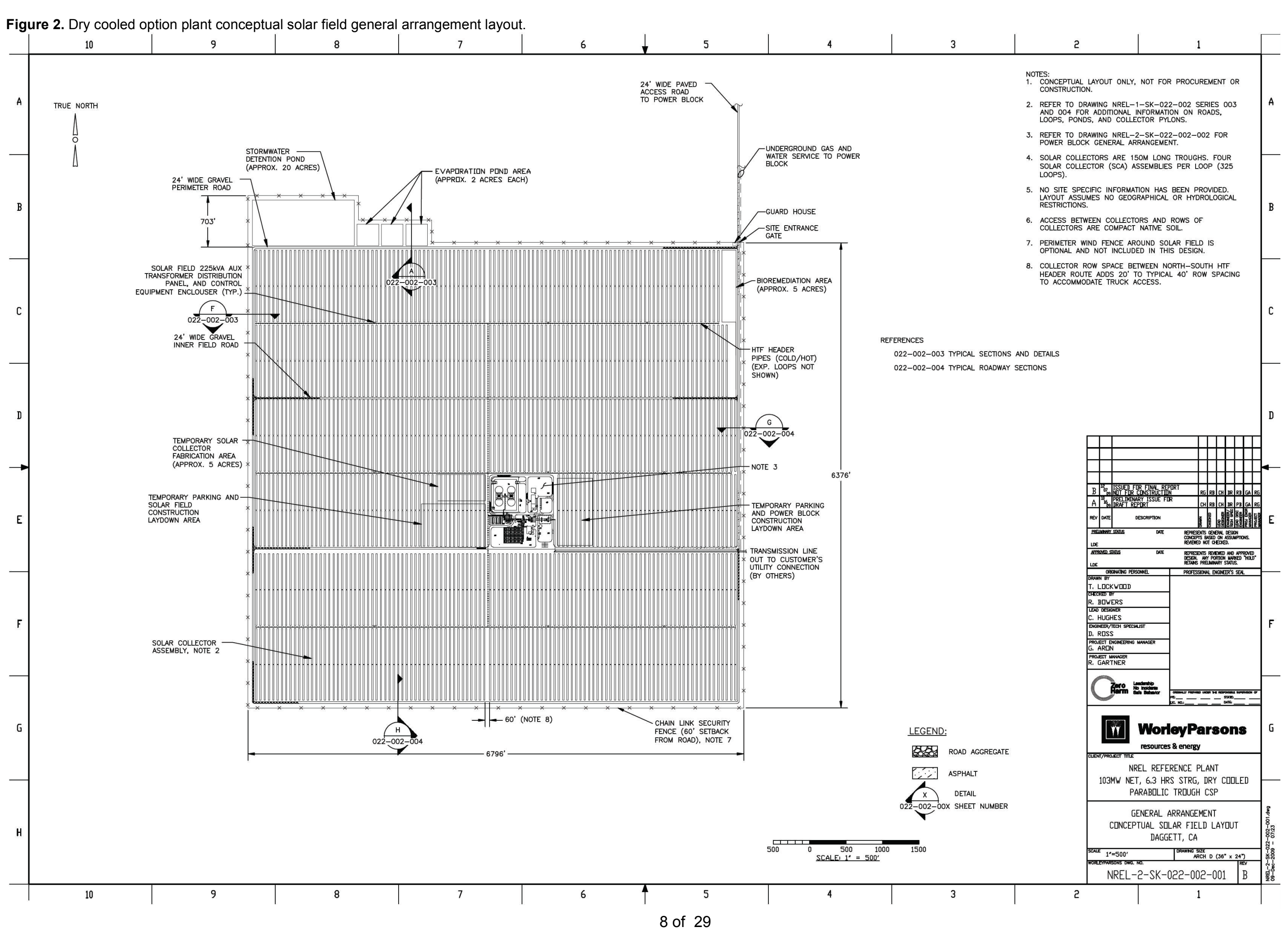




\section{WorleyParsons}

resources \& energy

DRY COOLING OPTION

NATIONAL RENEWABLE ENERGY LABORATORY

ADDENDUM TO: CSP PARABOLIC TROUGH PLANT COST ASSESSMENT

\subsubsection{Heat Transfer Fluid System}

The dry cooled solar collector field remains divided into 6 sections, as in the base case, and therefore maintains the same HTF pipe header lengths which supply fluid from the pumps to the loop headers at the inlet of each section (see Figure 2 above). However, additional SCAs will require new loop supply/return header piping which requires larger diameter header piping throughout the entire HTF piping network. The HTF volume of the larger system is 1.157 million gallons (4.38 million liters) at $100^{\circ} \mathrm{F}$. As a result, larger HTF circulation pumps are needed. The base case HTF expansion tank system, however, has enough available capacity with its single expansion tank and six overflow tanks to accommodate the dry cooled design.

Due to physical and performance limitations of HTF pumps, five (5) $25 \%$ capacity centrifugal type circulation pumps driven by $3000 \mathrm{hp}$ motors (with variable speed drives) are required in the dry cooled design. The wet cooled design required four (4) $33 \%$ capacity $4000 \mathrm{hp}$ pumps. In comparison, the wet cooled plant's HTF pumps (at design conditions) consume $7.86 \mathrm{MWe}$ of auxiliary power while the dry cooled plant's HTF pumps consume 8.40MWe.

No significant changes to the HTF ullage, freeze protection and nitrogen systems were necessary and therefore no changes were made at this preliminary design level.

\subsubsection{Power Cycle}

Figure 3 below illustrates the dry cooled power cycle in more detail and includes high-level thermal storage and water treatment processes.

Conceptual Rankine cycle heat balances were modeled using General Electric's GateCycle ${ }^{\mathrm{TM}}$ software at three ambient conditions. The design case sets all equipment sizes based on peak ambient weather data as previously described. In addition, two off-design cases are modeled for winter and annual average ambient conditions at $100 \%$ solar heat input to the steam cycle. 


\section{WorleyParsons}

resources \& energy

DRY COOLING OPTION

NATIONAL RENEWABLE ENERGY LABORATORY

ADDENDUM TO: CSP PARABOLIC TROUGH PLANT COST ASSESSMENT

Table 3. Heat balance output summary for dry cooled option. Not all model outputs are shown.

\begin{tabular}{|c|c|c|c|c|}
\hline $\mathrm{De}$ & cription & Design Case & $\begin{array}{l}\text { Winter } \\
\text { Average }\end{array}$ & $\begin{array}{l}\text { Annual } \\
\text { Average }\end{array}$ \\
\hline Ambinnt Conditions & DB Temperature $\left({ }^{\circ} \mathrm{F} /{ }^{\circ} \mathrm{C}\right)$ & $108.0 / 42.2$ & $58.9 / 14.9$ & $81.5 / 27.5$ \\
\hline Amolem comantus & Relative Humidity (\%) & 17 & 29 & 23 \\
\hline System Performance & Gross Power Output (kW) & 120,483 & 127,592 & 127,093 \\
\hline HTF to SSGs & Flow (lb/hr / kg/min) & $\begin{array}{c}1,061,541 / \\
83,624\end{array}$ & $\begin{array}{c}1,061,541 / \\
83,624\end{array}$ & $\begin{array}{c}11,061,541 \\
/ 83,624\end{array}$ \\
\hline & Temp $\left({ }^{\circ} \mathrm{F} /{ }^{\circ} \mathrm{C}\right)$ & $740 / 393.3$ & $740 / 393.3$ & $740 / 393.3$ \\
\hline & Flow (lb/hr / kg/min) & $\begin{array}{c}1,135,687 / \\
8,585\end{array}$ & $\begin{array}{c}1,135,654 / \\
8,585 \\
\end{array}$ & $\begin{array}{c}1,135,655 / \\
8,585\end{array}$ \\
\hline HP Steam to STG & Temp ( $\left.{ }^{\circ} \mathrm{F} /{ }^{\circ} \mathrm{C}\right)$ & $700 / 371$ & $700 / 371$ & $700 / 371$ \\
\hline & Press (psia / bar) & $1,325 / 91.4$ & $1,325 / 91.4$ & $1,325 / 91.4$ \\
\hline & Enthalpy (BTU/lb) & 1,301 & 1,301 & 1,301 \\
\hline & Flow (lb/hr / kg/min) & $\begin{array}{c}984,205 / \\
7,440\end{array}$ & $\begin{array}{c}983,968 / \\
7,439\end{array}$ & $\begin{array}{c}983,985 / \\
7,439\end{array}$ \\
\hline HRH Steam to STG & Temp $\left({ }^{\circ} \mathrm{F} /{ }^{\circ} \mathrm{C}\right)$ & $700 / 371$ & $700 / 371$ & $700 / 371$ \\
\hline & Press (psia / bar) & $362 / 25$ & $362 / 25$ & $362 / 25$ \\
\hline & Enthalpy (BTU/lb) & 1365 & 1365 & 1365 \\
\hline & Flow (lb/hr / kg/min) & $\begin{array}{c}808,477 / \\
6,112 \\
\end{array}$ & $\begin{array}{c}783,270 / \\
5,921\end{array}$ & $\begin{array}{c}787,142 / \\
5,951 \\
\end{array}$ \\
\hline From Condenser & Temp $\left({ }^{\circ} \mathrm{F} /{ }^{\circ} \mathrm{C}\right)$ & $133 / 56.1$ & $102 / 38.9$ & $107 / 40.6$ \\
\hline Hotwell & Press (psia / bar) & $\begin{array}{l}2.41 / \\
0.166 \\
\end{array}$ & $\begin{array}{c}1.02 / \\
0.0703\end{array}$ & $\begin{array}{c}1.18 / \\
0.0814\end{array}$ \\
\hline & Enthalpy (BTU/lb) & 100.9 & 70.5 & 75.4 \\
\hline
\end{tabular}




\section{WW WorleyParsons}

resources \& energy

DRY COOLING OPTION

NATIONAL RENEWABLE ENERGY LABORATORY

ADDENDUM TO: CSP PARABOLIC TROUGH PLANT COST ASSESSMENT

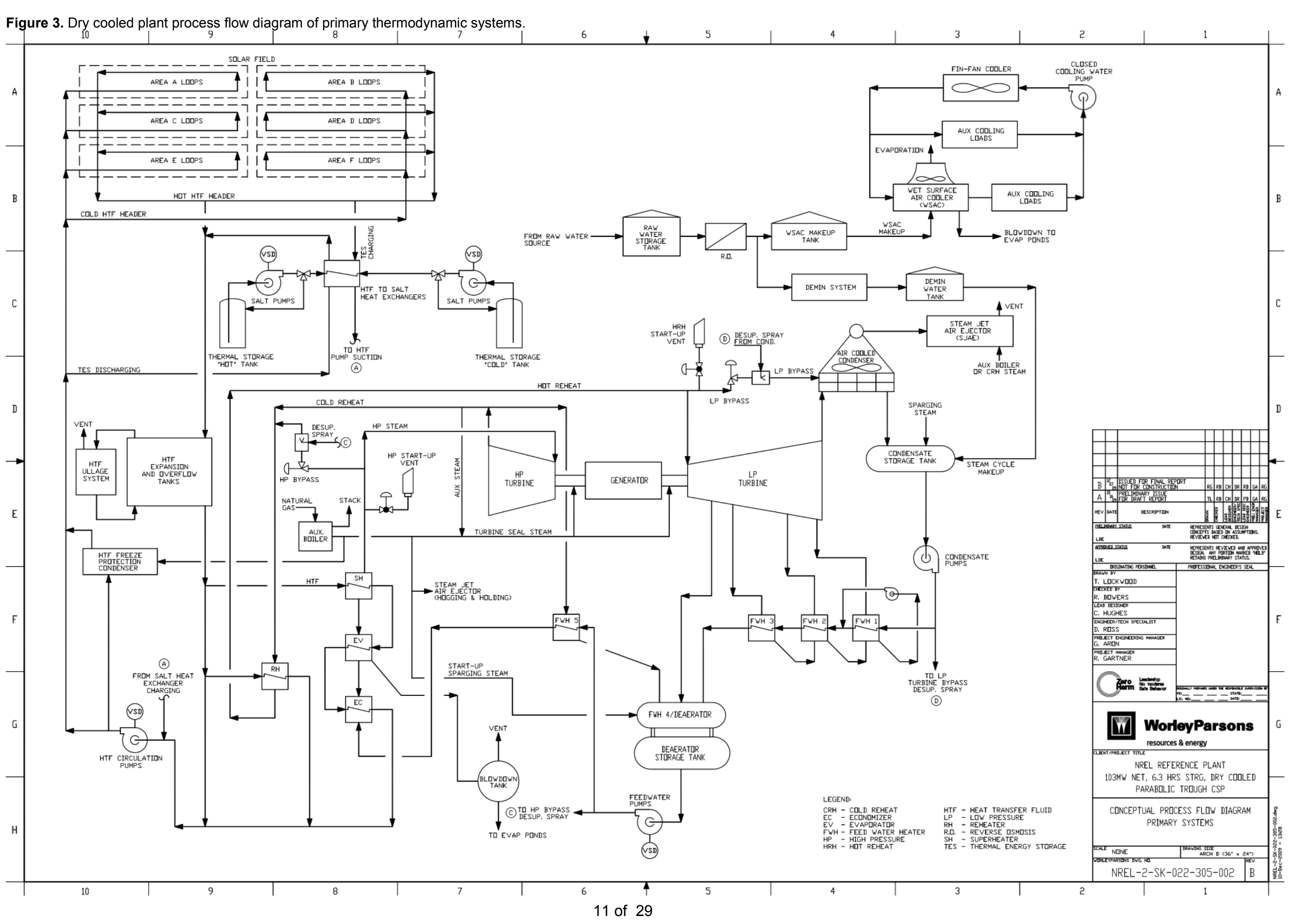




\title{
WorleyParsons
}

resources \& energy

\author{
DRY COOLING OPTION \\ NATIONAL RENEWABLE ENERGY LABORATORY \\ ADDENDUM TO: CSP PARABOLIC TROUGH PLANT COST ASSESSMENT
}

\section{WATER BALANCE}

Water balance calculation results for the three heat balance cases are shown in Figures 4 to 6 below. The water balance is representative of simultaneous operating consumers at full turbine output for a given ambient condition. Intermittent and emergency users (firewater, hose streams, safety showers, etc.) are not running during normal operation and are therefore excluded from the water balance. Mirror wash water consumption is shown coincident to Rankine cycle operation for clarity, although it will more frequently be performed off-line.

With an air cooled condenser, no cooling tower makeup water is needed to replace the evaporated cooling water as in the wet cooled design. Therefore, the dry cooled plant has significantly less water consumption with its primary consumer being the demineralized water users (steam cycle and mirror washing). At design operating conditions, approximately $91 \%$ of the incoming raw water is treated by reverse osmosis (RO); the other $9 \%$ is used as miscellaneous domestic water and blowdown quench water in the steam cycle. About $22 \%$ of the RO feed is rejected to the evaporation ponds. Approximately $11 \%$ of the RO product is used as WSAC makeup, the remainder is sent to the electrostatic deionization system to produce demineralized water. Altogether plant demineralized water accounts for $\sim 64 \%$ of the plant's total water consumption at design point (not representative of annual consumption).

The base case wet cooled plant is estimated to consume 1241 acre-feet/year of raw water for operational use during a typical year. In contrast, for the same net power out, the dry cooled plant is estimated to consume 90 Acre-feet/year, about $7 \%$ of the wet cooled plant consumption. Below is a breakdown of raw water consumers for each cooling case.

\section{$\underline{\text { Wet Cooled }}$}

- 1165 acre-feet/year, cooling tower make-up

- 23 acre-feet/year, blowdown quench \& steam cycle make-up

- 13 acre-feet/year, steam cycle make-up (during plant startup)

- 40 acre-feet/year, mirror washing

\section{Dry Cooled}

- 3 acre-feet/year, WSAC make-up

- 24 acre-feet/year, blowdown quench \& steam cycle make-up

- 19 acre-feet/year, steam cycle make-up (during plant startup)

- 44 acre-feet/year, mirror washing

Due to the slightly larger steam flow in the dry cooled plant, respective increases in blowdown quench and steam cycle make-up water result. Mirror wash water consumption also slightly increases due to the larger solar field of the dry cooled plant. No economic conclusions are provided in this study as initial and operating costs are heavily dependent on available water quality and quantity specific to the plant site. Likewise, no pre or post water treatment systems are included in the cost estimate. 


\section{WorleyParsons}

resources \& energy

\section{DRY COOLING OPTION}

NATIONAL RENEWABLE ENERGY LABORATORY

ADDENDUM TO: CSP PARABOLIC TROUGH PLANT COST ASSESSMENT

Figure 4. Dry cooled plant design case water balance at $108^{\circ} \mathrm{F}\left(42.2^{\circ} \mathrm{C}\right) \mathrm{DB}$ and $71.3^{\circ} \mathrm{F}\left(21.8^{\circ} \mathrm{C}\right) \mathrm{WB}$ ambient temperatures. Diagram is high-level and not inclusive of all water system processes.

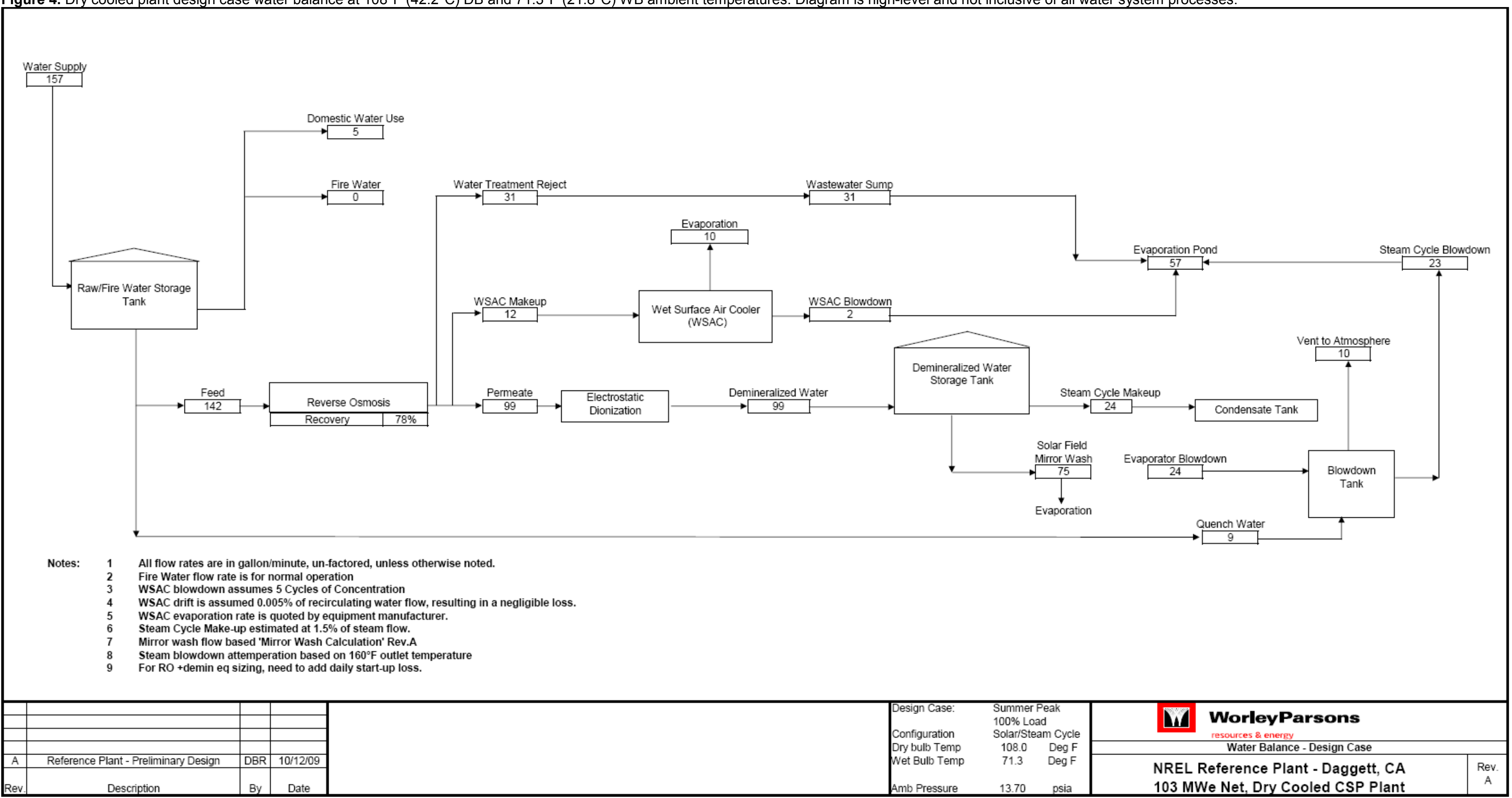




\section{WW WorleyParsons}

resources \& energy

\section{DRY COOLING OPTION}

NATIONAL RENEWABLE ENERGY LABORATORY

ADDENDUM TO: CSP PARABOLIC TROUGH PLANT COST ASSESSMENT

Figure 5. Dry cooled plant annual average case water balance at $81.5^{\circ} \mathrm{F}\left(27.5^{\circ} \mathrm{C}\right) \mathrm{DB}$ and $58.1^{\circ} \mathrm{F}\left(14.5^{\circ} \mathrm{C}\right)$ WB ambient temperatures. Diagram is high-level and not inclusive of all water system processes.

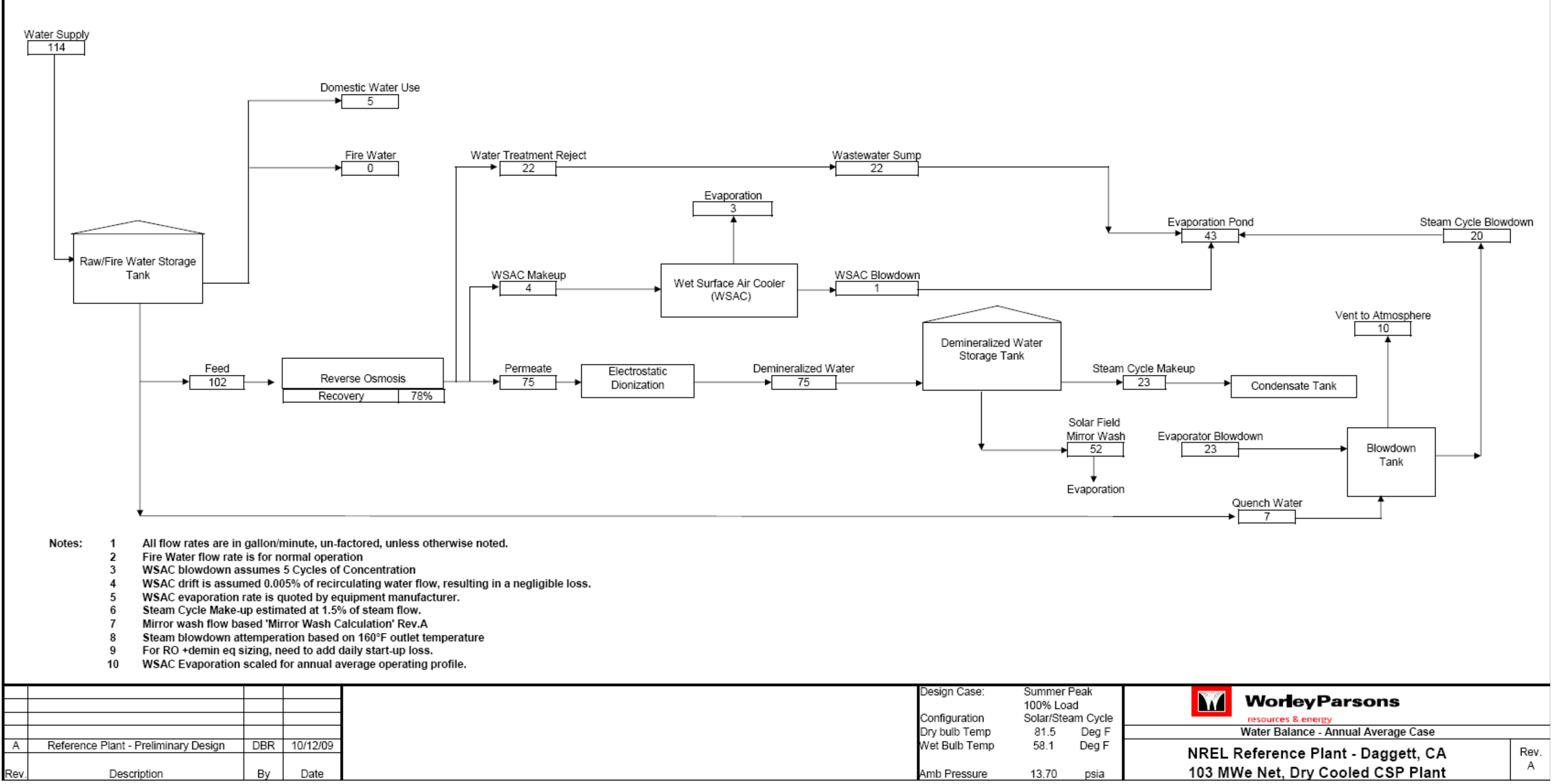




\section{WorleyParsons}

resources \& energy

\section{DRY COOLING OPTION}

NATIONAL RENEWABLE ENERGY LABORATORY

ADDENDUM TO: CSP PARABOLIC TROUGH PLANT COST ASSESSMENT

Figure 6. Dry cooled plant winter average case water balance at $58.9^{\circ} \mathrm{F}\left(14.9^{\circ} \mathrm{C}\right) \mathrm{DB}$ and $44.4^{\circ} \mathrm{F}\left(6.9^{\circ} \mathrm{C}\right) \mathrm{WB}$ ambient temperatures. Diagram is high-level and not inclusive of all water system processes

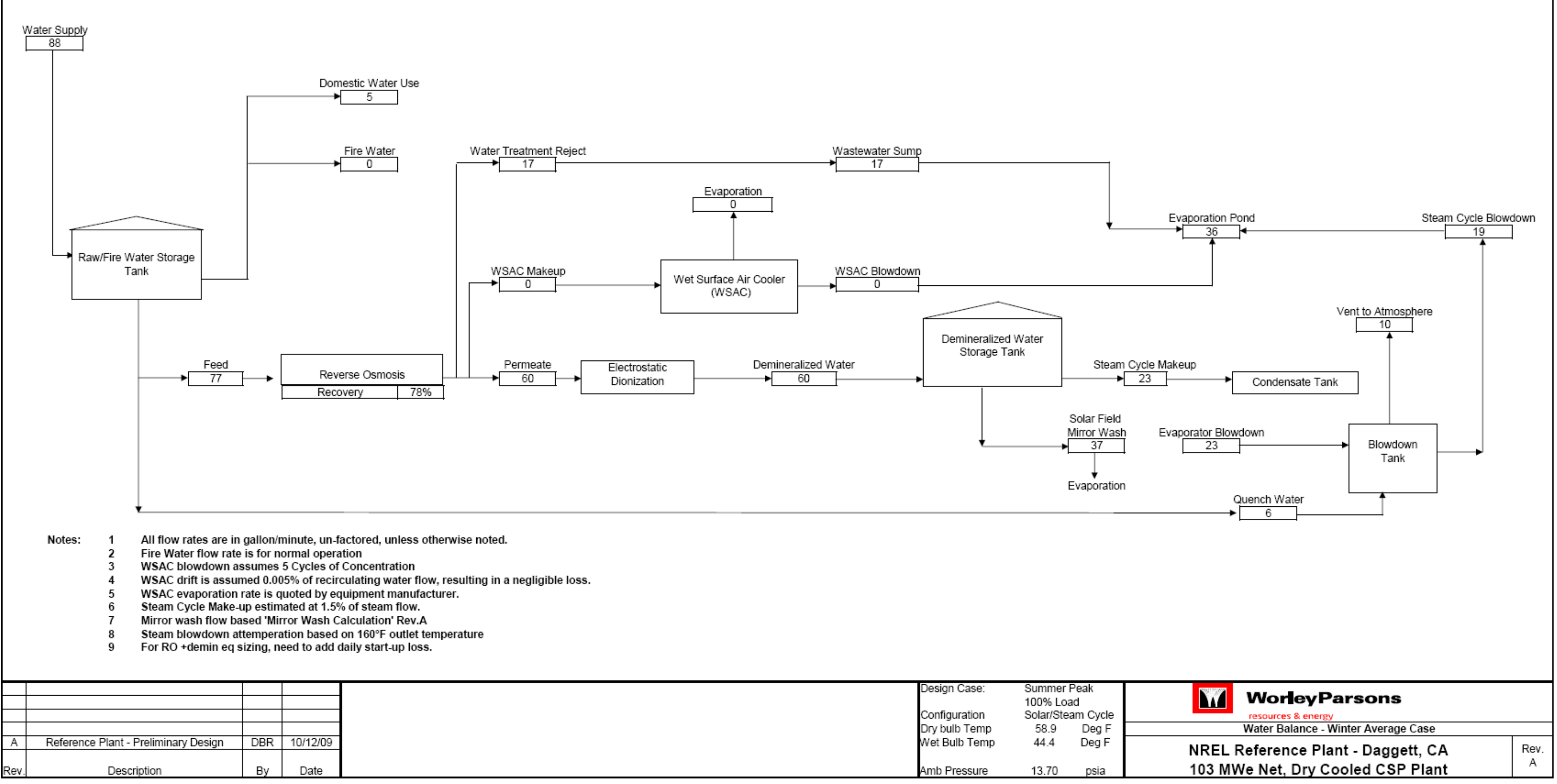




\title{
WorleyParsons
}

resources \& energy

\author{
NATIONAL RENEWABLE ENERGY LABORATORY \\ CSP PARABOLIC TROUGH PLANT COST ASSESSMENT
}

\begin{abstract}
RANKINE EQUIPMENT
The dry cooled plant uses the same two full capacity centrifugal-type ring section multistage feedwater pumps, however, with an increase in motor size from $3000 \mathrm{hp}$ (wet) to $3500 \mathrm{hp}$ (dry). While the connected available motor power is $500 \mathrm{hp}$ greater, the peak operating load is only $200 \mathrm{hp}(149 \mathrm{~kW})$ greater. The larger feedwater pumps are needed to accommodate the increase in steam flow through the larger steam turbine. Similarly, condensate pumps have no change in pump type or configuration. Although they maintain $350 \mathrm{hp}$ connected motor size from the wet to dry plant design, they require an additional $30 \mathrm{hp}(22 \mathrm{~kW})$ at peak operation.
\end{abstract}

The dry cooled Rankine cycle steam flow is not a large enough increase to warrant any physical changes in quantity or configuration of the solar steam generator (SSG) equipment. The increase in shell and tube dimensions will be insignificant and was not determined at this preliminary design level. Therefore the general arrangement drawing shows no physical change in sizes for the solar steam generators; however, costs have been adjusted appropriately.

An alternative reheat STG was selected for the dry cooled plant power block equipment layout, capable of up to $150 \mathrm{MWe}$, has a single flow LP section with last stage blades designed for dry condensing. Unlike the industrial-scale unit used in the wet cooled base design, the utility-scale turbine locates its generator at the end of the turbine train where it directly couples with the common HP/LP shaft. No speed reduction gear box is needed with this larger steam turbine. Since the HP turbine operates at lower speeds than the wet-cooled machine, the dry-cooled turbine is able to set both HP and LP turbines on a single shaft at $3600 \mathrm{rpm}$ (generator speed). This arrangement is typical of most utility-scale steam turbines and offers easier access to the generator rotor for removal during heavy maintenance activity.

The scope of supply is nearly the same for both machines. The only difference is the type of enclosures provided in each supplier's base scope; taking into account that specific enclosure specifications can be requested at the buyer's expense. The dry-cooled turbine selected for this study provides an enclosure for its generator, oil conditioning equipment, and excitation room; whereas the wet-cooled unit encloses the full turbine train (turbines and generator) but includes no covering for its oil conditioning equipment.

One supplier is not necessarily better suited than the other for dry-cooling. Use of the selected turbine for the dry-cooled plant is fully based on the amount of equipment information available at the time of the study.

\section{Air Cooled Condenser}

The dry cooled alternative equipment includes a self-contained 25-cell air cooled condenser having 5 cells in each of its 5 bays and an initial temperature difference (ITD) of $\Delta 25^{\circ} \mathrm{F}$ at design conditions. ITD is defined as the difference between ambient dry bulb temperature and steam saturation temperature at the turbine exhaust. The ACC size is driven by the selected ITD which was optimized for this study based on a high level cost and performance analysis between solar field size, ACC cost, parasitic load and net power output to the grid. An ACC designed with a $\Delta 25^{\circ} \mathrm{F} \mathrm{ITD}$ at a design ambient dry bulb temperature of $108^{\circ} \mathrm{F}\left(42.2^{\circ} \mathrm{C}\right)$ corresponds to a $133^{\circ} \mathrm{F}$ saturation temperature and respective 2.41 psia (0.1662 bar) turbine back pressure. 


\title{
WorleyParsons
}

resources \& energy

\author{
NATIONAL RENEWABLE ENERGY LABORATORY \\ CSP PARABOLIC TROUGH PLANT COST ASSESSMENT
}

Exhaust steam exits the LP turbine through the main exhaust duct, a carbon steel duct measuring 178-inches (4.52 meters) in diameter. The main duct length is minimized to the greatest extent possible in order to mitigate performance-inhibiting pressure losses that have a significant impact on turbine efficiency. A drip-leg is provided in the exhaust duct to collect the condensate in the exhaust steam (i.e. exhaust steam quality is less than $100 \%$ ). This main exhaust duct supplies saturated steam to the perpendicular "streets" (rows of bays) at the top of the tower. Ambient air is forced vertically through the 116-foot (35.4-meter) tall tower with twenty five (25) fans 36 -feet ( 11 meter) in diameter. Each fan is driven by a single-speed $200 \mathrm{hp}$ motor which requires speed reduction via a parallel shaft gear train. Altogether the ACC utilizes 3,570 $\mathrm{kWe}$ at design conditions.

Through forced convection heat transfer the saturated steam condenses as it gravitationally drops down the aluminum-finned tubes arranged in an "A" shape. Condensate collects in the condensate tank (typically supplied by the ACC manufacturer) located beneath the ACC tower. Condensate pumps forward the condensate through the low pressure feedwater heaters and into the deaerator (refer to Figure 3).

\subsubsection{Thermal Energy Storage}

Higher STG output and lower thermal-to-electric efficiency in the dry cooled plant requires an additional 156 MWth-hrs of TES capacity to meet 6.3 hours provided in the base plant design. This larger TES system will store up to $2144 \mathrm{MWth}$-hrs of thermal energy versus the $1988 \mathrm{MWth}-$ hrs stored in the wet cooled design; the salt mass therefore increases from 62kMT to 66.8kMT. The storage tanks are assumed to slightly increase in height to accommodate the larger salt mass. TES pumps are assumed to have no change in quantity or motor size but to have a slight linear increase in operating electric load based on the increased charge and discharge rates. The quantity of oil-to-salt heat exchangers per module increases from 3 to 4 , totaling 8 for the entire TES system. This quantity increase is based on WorleyParsons' past project archive with larger TES systems and their impact on heat exchanger configuration.

\subsubsection{Balance of Plant}

Changing from wet to dry cooling yields small changes to the balance of plant mechanical systems, with the exception of auxiliary cooling later discussed. Major BOP systems not changed in the alternative condensing design include: fire protection, drains, demineralized water, potable water, sanitary drains, fuel gas, and compressed air. Refer to the base report for a brief description of these systems. BOP systems affected by the alternate design are discussed below.

\section{AUXILIARY COOLING}

For an ACC facility, the traditional ultimate heat sink (wet tower) for the Closed Cooling Water (CCW) system is no longer available. An addition of a new heat sink must be added to the design. The dry cooled plant's CCW heat exchangers are replaced with either an air cooled heat exchanger (fin-fan cooler) or a combination of a fin-fan and a wet surface air cooler (WSAC) as a source to cool the CCW. In climates cooler than the Mojave Desert, a stand alone fin-fan cooler is sufficient to handle all auxiliary cooling loads and provide cooling water at temperatures meeting equipment requirements. Since Daggett typically experiences high dry bulb 


\title{
WorleyParsons
}

resources \& energy

\author{
NATIONAL RENEWABLE ENERGY LABORATORY \\ CSP PARABOLIC TROUGH PLANT COST ASSESSMENT
}

temperatures, the fin-fan cooler would be unable to meet the strict cooling water temperatures required by the STG lube oil cooler and sample panel cooler (and possibly other equipment coolers). Therefore a WSAC, which uses evaporative cooling, is added in series with the fin-fan cooler and will operate when the ambient dry bulb temperature exceeds $85^{\circ} \mathrm{F}\left(29.4^{\circ} \mathrm{C}\right)$. The WSAC cooler is sized to handle auxiliary cooling loads that require a maximum of $\sim 100^{\circ} \mathrm{F}$ cooling water at all times. At high ambient temperatures, the WSAC is used to further cool the CCW coming from the fin-fan to satisfy the STG lube oil cooler, sample panel cooler and any other cooling loads that require $<100^{\circ} \mathrm{F}$ cooling water. This arrangement minimizes water consumption.

The CCW expansion tank and CCW pumps are still needed in the dry plant design; however the auxiliary cooling water pump and plate-and-frame heat exchangers are no longer applicable. The WSAC requires its own set of relatively small cooling water pumps to circulate the water that is evaporated.

\begin{abstract}
AUXILIARY STEAM
A natural gas fired auxiliary boiler is needed in the dry cooled design and serves the same auxiliary steam hosts as in the wet cooled plant; HTF freeze protection, hogging and holding air ejectors, gland steam for turbine seals, and sparging steam for startup. In the base design the boiler size was dictated by a $12 \mathrm{MMBtu} / \mathrm{hr}$ HTF freeze protection duty. Because the ACC holds much more volume than the surface condenser, the hogging steam flow needed to initiate vacuum conditions nearly doubled, .Consequently, the auxiliary boiler size increases to 18 $\mathrm{MMBtu} / \mathrm{hr}$.
\end{abstract}

\section{BLOWDOWN}

The same steam cycle blowdown process applies to the dry cooled Rankine cycle. The only difference is the condensed blowdown wastewater is sent to a wastewater sump rather than the cooling tower basin. This wastewater sump also collects WSAC blowdown and water treatment reject streams. Sump pumps forward all wastewater to onsite evaporation ponds.

\section{RAW WATER}

Well water forwarding pumps remain as three (3) by $50 \%$ capacity centrifugal type pumps but have a decreased motor size from $250 \mathrm{hp}$ (wet) to $75 \mathrm{hp}$ (dry). The underground supply pipeline decreases from 10-inch to 3 -inch high density polyethylene (HDPE) plastic pipe. There is no change in well location, size, and configuration assumptions.

The field-erected carbon steel raw water storage tank is sized to provide 14 hours of blowdown quench, demineralized water, and service water usage. A dedicated reserve of firewater is also stored in the tank providing 360,000 gallons (1,362,748 liters) or 2 hours at $3000 \mathrm{gpm}$ (189 liters/sec). Service water pumps are identical in size and service between the wet and dry designs.

\subsection{Electrical System Descriptions}

All high voltage electrical equipment is unchanged. The same generator step-up transformer and switchyard can be used in the dry cooled plant. The changes in electrical systems are primarily seen at the medium (4160V) and low (480V) voltage levels. The solar field power distribution 


\section{WorleyParsons}

resources \& energy

\section{NATIONAL RENEWABLE ENERGY LABORATORY CSP PARABOLIC TROUGH PLANT COST ASSESSMENT}

design and its equipment are largely unchanged from the base design except a linear increase in power cable feeding the SCA drives.

Below is a list of the major electrical equipment modifications from the base plant design. Bulk electrical materials such as cable, connectors, panel boards etc. are not listed at this design level, but are included in the cost estimate.

Table 4. Dry cooled plant major electrical equipment modifications to the base plant design.

\begin{tabular}{|l|l|}
\hline EQUIPMENT NAME & QTY \\
\hline Station Service Transformers & 9 \\
\hline Solar Collector Drive Power Converters & 1300 \\
\hline $\begin{array}{l}\text { Power Distribution Center (PDC1A) with Switchgear and Motor Control } \\
\text { Centers (MCC) - TES Area }\end{array}$ & 1 \\
\hline $\begin{array}{l}\text { Power Distribution Center (PDC2A) with Switchgear and Motor Control } \\
\text { Centers (MCC) - STG \& Solar Field Areas }\end{array}$ & 1 \\
\hline $\begin{array}{l}\text { Power Distribution Center (PDC2B) with Switchgear and Motor Control } \\
\text { Centers (MCC) - ACC \& HTF Areas }\end{array}$ & 1 \\
\hline
\end{tabular}

The two auxiliary transformers slightly increase to 19/25/31 MVA to accommodate the larger parasitic load required by the added ACC fans and larger HTF pumps. There will be three power distribution centers (PDC) containing the switchgear and MCC equipment supplying $480 \mathrm{~V}$ and $4160 \mathrm{~V}$ power to the end users. No change in essential service loads and therefore no change in diesel generator size. 


\section{Wi] WorleyParsons}

resources \& energy

NATIONAL RENEWABLE ENERGY LABORATORY

CSP PARABOLIC TROUGH PLANT COST ASSESSMENT

Figure 7. Conceptual electrical one-line diagram including all $4160 \mathrm{~V}$ connected equipment. Sheet 1.

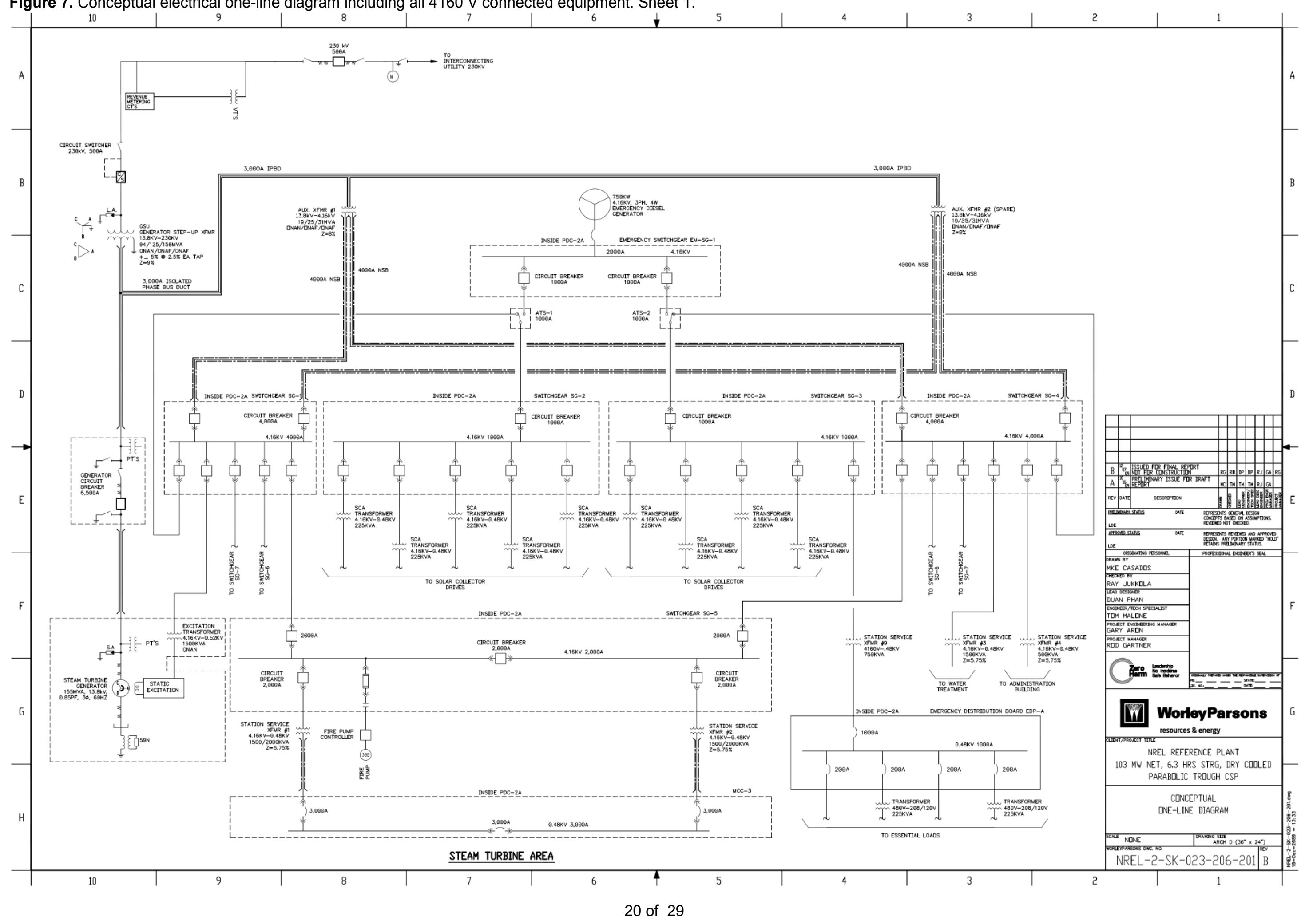




\section{Wi WorleyParsons}

resources \& energy

NATIONAL RENEWABLE ENERGY LABORATORY

CSP PARABOLIC TROUGH PLANT COST ASSESSMENT

Figure 8. Conceptual electrical one-line diagram including all $4160 \mathrm{~V}$ connected equipment. Sheet 2 .

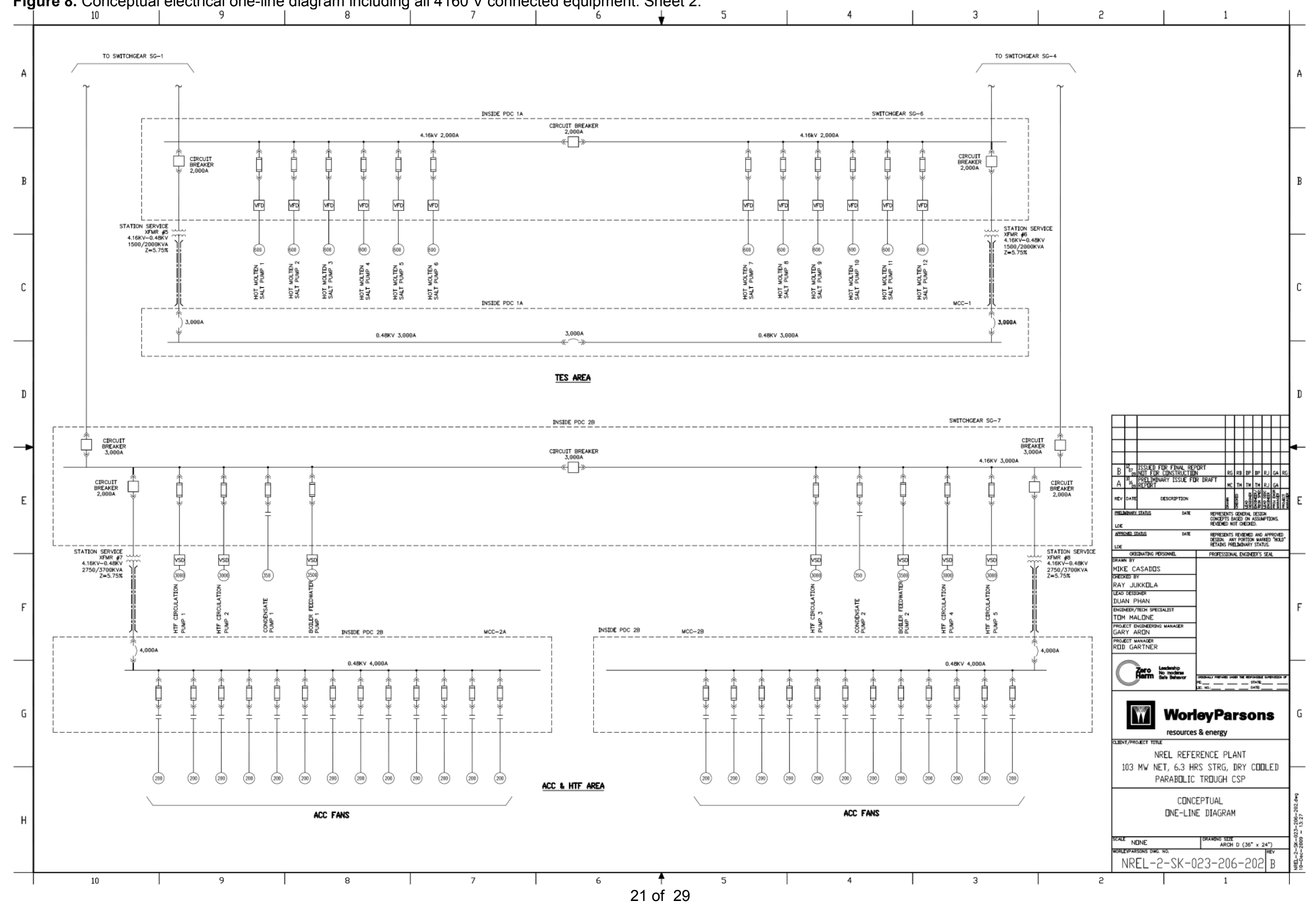




\section{WorleyParsons}

resources \& energy

NATIONAL RENEWABLE ENERGY LABORATORY

CSP PARABOLIC TROUGH PLANT COST ASSESSMENT

\subsection{Instrumentation and Control System Descriptions}

The power block distributed control system (DCS) remains unchanged.

Solar field control system design is unchanged from the base design with the exception of increased control cable and I/O quantities for the increased number of SCA drives.

\subsection{Civil Sitework Descriptions}

\subsubsection{Roads, Parking, and Fencing}

The base design remains largely unchanged with only a small increase in roads and fencing lengths due to the larger solar field.

\subsubsection{Bioremediation / Land Farm Area}

The base design remains unchanged.

\subsubsection{Site Preparation, Earthwork, and Improvements}

The base design remains largely unchanged with only a small increase due to the larger solar field.

\subsubsection{Onsite Drainage, Detention, and Evaporation Ponds}

The base design concept remains unchanged. Evaporation ponds decrease from a total of 60 acres to 6 acres due to the absence of cooling tower blowdown.

\subsubsection{Thermal Storage Salt Containment Berm}

The base design remains unchanged.

\subsection{Structural Support and Foundation Descriptions}

\subsubsection{Solar Field Structures and Foundations}

The base design remains unchanged, with the only increase due to longer HTF pipe runs for the larger solar field. 


\section{WorleyParsons}

resources \& energy

NATIONAL RENEWABLE ENERGY LABORATORY CSP PARABOLIC TROUGH PLANT COST ASSESSMENT

\subsubsection{Power Block Structures and Foundations}

The base design BOP structures/foundations remain largely unchanged, with the exception of added WSAC, fin-fan, and WSAC make-up tank foundations. The cooling tower basin has been deleted and ACC support piers added. 


\section{WorleyParsons}

resources \& energy

NATIONAL RENEWABLE ENERGY LABORATORY

CSP PARABOLIC TROUGH PLANT COST ASSESSMENT

\section{COST ESTIMATE BASIS}

The estimate is based on an Engineer - Procure - Construction Management (EPCM) approach. Engineering and Design, Construction Management, and Start-up \& Commissioning costs are included.

Material Take-off (MTO) and Design Allowances are included in the estimate and are intended to compensate for the degree of engineering that is incomplete. This is not a contingency; rather it is a minor allowance included to cover the nominal quantity growth which inevitably occurs as the design is further developed.

Contractor mark-up on bulk materials reflects the mark-up that contractors will apply to bulk materials provided under their respective contracts. A rate of $5 \%$ is used for these materials. This has been reduced from the more typical rate of $8 \%$ to account for the "engineered bulks", including most of the piping being supplied by the EPCM contractor and thus not being subject to a mark-up..

The estimate excludes escalation. All costs are presented as overnight 2nd Quarter 2009 dollars.

Project Contingency addresses unforeseen elements of costs within the current defined project scope. It is expected that by the end of the project the entire contingency will be spent on either direct or indirect costs. The contingency is applied as follows, $5 \%$ on equipment, $10 \%$ on bulk material, $10 \%$ on installation labor for the solar field and $15 \%$ on the balance of installation labor, and $0 \%$ on professional services.

\subsection{Quantity Development}

Equipment quantities for major equipment components are based on preliminary engineering provided in drawings, flow diagrams, process and instrumentation diagrams (P\&ID's), equipment lists, and electric one-line diagrams. Major piping networks such as HTF, steam, feedwater, condensate, and firewater were conceptually laid out and specified on P\&ID's.

Minor balance of plant equipment not included in the project design documents are based on similar plant designs previously developed by WorleyParsons. Examples of minor balance of plant equipment include steam turbine gland steam seal system, condenser air removal system, service air system, steam / water sampling system, and compressed air systems. Bulk material quantities were developed for select major systems based on conceptual routings and sizing where available. Quantities for the balance of plant systems were developed by scaling from a similarly sized plant to meet specific NREL site requirements.

\subsection{Material and Equipment Pricing}

All applicable vendor quotes obtained in the wet cooled plant estimate were used in the dry cooled plant and appropriately scaled if necessary. The following equipment costs are based on budgetary quotes specifically obtained for the dry cooled plant: 


\section{WorleyParsons}

resources \& energy

NATIONAL RENEWABLE ENERGY LABORATORY CSP PARABOLIC TROUGH PLANT COST ASSESSMENT

- Steam turbine generator, gland steam condenser, and lube oil skid

- Air Cooled Condenser

- Fin-fan cooler

- Wet surface air cooler

Remaining equipment costs are based on WorleyParsons cost estimating database, adjusted to 2Q2009 dollars. The bulk material costs are based on recent pricing for similar materials from the WorleyParsons estimating database, adjusted to 2Q2009 dollars. Most of the equipment and materials will be transported by truck to the project site.

\subsection{Construction Labor}

Overall construction labor costs include wage rates, installation hours, labor productivity, labor availability and construction indirect costs.

\subsubsection{Wage Rates}

Union shop wage rates are based on the 2009 RS Means Labor Rates for the Construction Industry. Rates are based on Riverside, CA and are valid to 2Q 2009.

\subsubsection{Installation Hours}

WorleyParsons maintains a database of standard unit installation hours. The database represents standard installation rates for US Gulf Coast Merit Shop. Equipment setting manhours were developed by evaluating estimated weights, equipment size, and number of components in conjunction with crew sizes and approximated time. Bulk material man-hours are based on standard unit installation rates. The resultant hours are further adjusted for productivity (described below).

\subsubsection{Labor Productivity}

The estimate reflects productivity for the Daggett, CA area. In evaluating productivity, factors such as jobsite location, type of work (i.e. new construction) and site size are considered. Labor productivity factors (multipliers over US Gulf Coast Merit Shop) have been included to reflect anticipated site specific labor productivity. A productivity factor of 1.2 was applied to the USGC labor hours, with the exception of the SCA assembly work performed in the on-site fabrication structure and the hours associated with salt melting. No productivity adjustment was applied to furnish and erect quotes obtained specifically for this project.

\subsubsection{Labor Availability}

Labor is based on a 50 -hour work-week (5-10s). The estimate includes an allowance of $\$ 60 /$ day for travel and per diem. No additional incentives have been included to attract or retain craft labor. The estimate is based on an adequate supply of qualified craft personnel being available to staff this project. 


\section{WorleyParsons}

resources \& energy

NATIONAL RENEWABLE ENERGY LABORATORY CSP PARABOLIC TROUGH PLANT COST ASSESSMENT

\subsubsection{Construction Indirect Costs}

In addition to base wage rates and fringe benefits, labor costs include construction indirect costs consisting of:

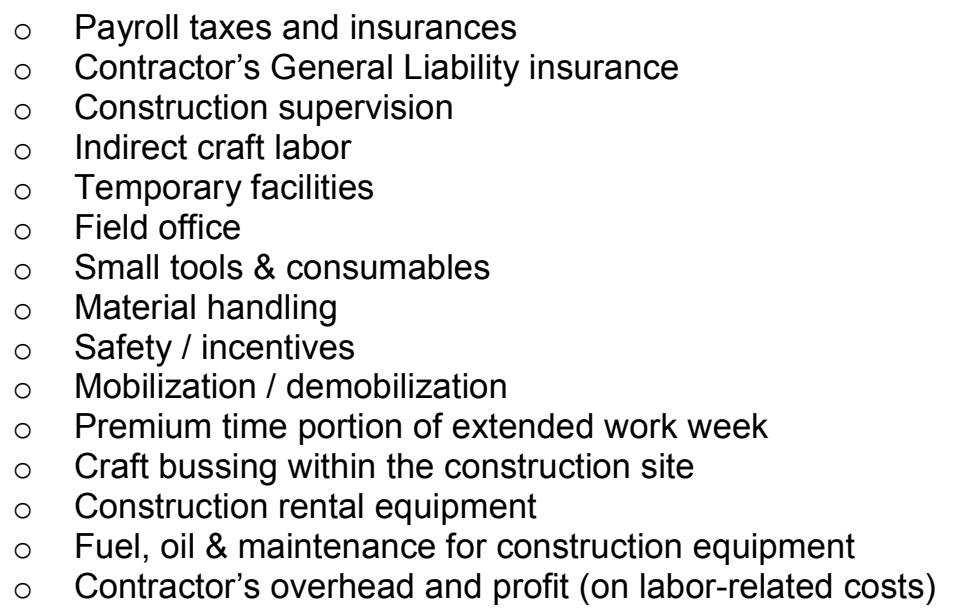

\subsection{Clarifications}

\subsubsection{Civil / Structural}

- The site is relatively flat. No underground obstructions, rock formations, or unusual site conditions exist.

- All grading will be balanced across the site.

- Earthwork (rough grading) is based on $1 \mathrm{ft}$ of earth movement over the entire solar field site.

- Site geography is assumed to have an average slope between $1 \%$ and $2 \%$ and can be graded with conventional equipment.

- Topsoil removal is not required. The topsoil will be scarified and compacted.

- Approximately 1024 acres $\left(4,143,980 \mathrm{~m}^{2}\right)$ of land will be cleared and grubbed. Desert vegetation (shrubs, etc.) covers the entire site.

- Dewatering is not required.

- The power block and access roads will be paved (asphalt or gravel). The solar field roads will be compacted native soil (proof rolled).

- Soil binder/stabilizer is not included for dust control at solar field roads.

$\circ$ The entire site will be fenced with 8 foot $(2.4 \mathrm{~m})$ high chain link fencing with barbed wire.

- The evaporation ponds will have a double HDPE liner. A leak detection system is included.

- The detention pond will be unlined with a compacted native soil bottom.

- The soil under the bio-remediation area will be lime treated.

- Concrete foundations are based on 4000 psi concrete. Piles are not required.

- Concrete foundations are included for all equipment and buildings. 


\section{WorleyParsons}

resources \& energy

NATIONAL RENEWABLE ENERGY LABORATORY CSP PARABOLIC TROUGH PLANT COST ASSESSMENT

- The steam turbine and ancillary equipment will be outdoors.

- Warehouse \& maintenance, water treatment, administration, and cooling tower chemical feed/storage buildings are included.

- A fabrication tent for the solar array structure assembly is included.

- Sanitary waste will not be piped offsite; rather it will run through a septic tank and run through an onsite leach field.

\subsubsection{Mechanical / Piping}

- The goal is to meet 103 MWe net and 6.3 hours of TES as provided in the wet cooled base case. The solar field and TES systems were increased to meet this goal.

- The thermal energy storage system is a completely installed, tested and commissioned turnkey EPC cost from a vendor, with the exception of the salt melting process.

- The salt fill will be delivered in one-tonne supersacs. Salt melting equipment and labor are included. Salt blending is not required, therefore, it is excluded.

- The solar collector field is laid out in a square-shaped array with a central power block to minimize HTF pumping loads.

- Blowdown will be discharged to three on-site evaporation ponds.

- Stress relieving for piping is included as required by code.

- Underground steel pipe is coated and wrapped.

- Expansion loops for the HTF piping are included.

- Water supply will be provided by three water wells. Electric well pump power is not included in the plant's auxiliary power load and will be purchased directly from the utility having jurisdiction.

- Water quality information is unknown and therefore no pre or post water treatment is included.

- A natural gas pipeline with adequate pressure is assumed to be available within reasonable proximity for plant interconnection (i.e. no onsite natural gas compression or propane storage is needed).

- SCA costs are estimated from individual component costs (mirror, structure, and receiver). Continuing changes in the industry appear to be resulting in a lower SCA cost than derived at the time of this cost estimate.

- An empirical sun-tracker using a shadowed PV plate concept is included on all SCAs. These are typically not needed if the drives have pre-programmed tracking logic built-in. The empirical tracker is included for redundancy per NREL's direction.

- A wind fence is excluded.

- Fire protection equipment is excluded from the solar field. Only power block equipment is protected.

\subsubsection{Electrical / Instrumentation}

- A 13.8kV-230kV generator step-up transformer is included.

- An on-site switchyard with 230kV main circuit breaker and main disconnect switches are included.

- No transmission lines beyond the switchyard are included. 


\section{WorleyParsons}

resources \& energy

\section{NATIONAL RENEWABLE ENERGY LABORATORY CSP PARABOLIC TROUGH PLANT COST ASSESSMENT}

- The estimate includes auxiliary transformers, station service transformers, and solar field transformers.

- SCA drive power converters are included.

- PDC buildings and equipment are included.

- Underground duct bank is included.

- Cathodic protection is included for underground piping.

\subsubsection{Other}

- Engineering work assumes that the selected site is void of all fatal-flaws which could significantly impact project cost and schedule. These flaws include, but are not limited to: habitat and locations of threatened-endangered and sensitive species, abundance of other protected (e.g., native) species, distribution of noxious weeds, areas of critical wildlife habitats and movement corridors, contaminated soil or hazardous materials, archaeological artefacts, distribution and significance of cultural resources, Native American Tribal concerns, recreational areas, special land use designations (e.g., BLM Areas of Environmental Concern), and others.

- Utility transmissions such as natural gas and supply water are included (excluding electric transmission) up to 200 feet off the furthest site boundary.

\subsection{Exclusions}

As discussed above, the scope of the estimates is generally limited to scope within the project fence. A list of items excluded from the estimate is as follows:

- Demolition and removal of existing structures

- Import duties \& tariffs

- Extraordinary noise mitigation or attenuation

- Owner's Costs

- Allowance for funds used during construction

- All taxes with the exception of payroll taxes

- All offsite infrastructure costs

- Upgrades to existing rail spur to accommodate delivery of large equipment

- Temporary housing and facilities for the construction workers

\subsubsection{Typical Owner's Costs}

Owner's costs are excluded from the estimate. Typical Owner's costs include, but are not limited to, the following:

○ Permits \& Licensing

- Land Acquisition / Rights of Way Costs

- Economic Development

- Project Development Costs (Geotechnical Investigation \& Site Survey)

- Legal Fees

- Owner's Engineering / Project \& Construction Management Staff

- Plant Operators during start-up 


\section{WorleyParsons}

resources \& energy

NATIONAL RENEWABLE ENERGY LABORATORY CSP PARABOLIC TROUGH PLANT COST ASSESSMENT

- Electricity consumed during start-up

Fuel and Reagent consumed during start-up

Initial Fuel \& Reagent Inventory

Transmission Interconnections \& Upgrades

Operating Spare Parts

Financing Costs 


\section{WorleyParsons}

resources \& energy

\section{APPENDIX A}

\section{Capital Cost Estimate Summary}


ESTIMATE SUMMARY

(Using Riverside, CA union labor rates)

NREL Task 1 Parabolic Trough Cost Assessment

$12 / 10 / 2009$

103 MW net with 6.3 hrs Thermal Storage - Dry Cooled Option

\begin{tabular}{|c|c|c|c|c|c|c|c|c|}
\hline ITEM & QTY & UNIT & & MATERIAL & & LABOR & TOTAL & COMMENTS \\
\hline Site Improvements & 1 & LS & $\$$ & $7,114,000$ & $\$$ & $15,723,000$ & $22,837,000$ & \\
\hline Solar Field & 1 & LS & $\$$ & $212,135,000$ & $\$$ & $284,253,000$ & $\$ \quad 496,388,000$ & \\
\hline HTF System & 1 & LS & $\$$ & $53,280,000$ & $\$$ & $56,749,000$ & $\$ \quad 110,029,000$ & \\
\hline Thermal Energy Storage & 1 & LS & $\$$ & $202,638,000$ & $\$$ & $5,438,000$ & $\$ 208,076,000$ & \\
\hline Fossil Backup & 1 & LS & $\$$ & - & $\$$ & - & $\$$ & \\
\hline Power Plant & 1 & LS & $\$$ & $112,136,000$ & $\$$ & $39,057,000$ & $\$ \quad 151,193,000$ & \\
\hline EPCM Costs & 1 & LS & & & & & $29,001,000$ & Professional services \\
\hline Project, Land, Misc. & 1 & LS & & & & & $\$$ & Excluded \\
\hline \%DC's Sales Tax Applies & 1 & LS & & & & & $\$$ & Excluded \\
\hline Subtotal & & & $\$$ & $587,303,000$ & $\$$ & $401,220,000$ & $\$ 1,017,524,000$ & \\
\hline Contingency & & & & & & & $79,227,000$ & \\
\hline TOTAL ESTIMATE - EPCM BASIS & & & & & & & $\$ 1,096,751,000$ & \\
\hline
\end{tabular}

\section{CRITICAL NOTES}

1 Thermal energy storage equipment cost is based on a turnkey budgetary quote from the single commercially available salt storage vendor. An alternative cost savings approach would be to estimate the storage system from the ground up and compile vendor quotes for each sub-component (tanks, pumps, HX, etc.)

2 NREL has selected a 2.0 solar multiple. The solar multiple has a significant capital cost impact and is subject to the project developer's financial model.

3 Cost reflects NREL's selected 150-meter trough design. This trough is the most proven design with the most utility-scale installations; however, the associated materials and labor costs are higher than alternative emerging designs (i.e. 100-meter trough, or SkyFuel)

4 Labor rates are union-based for Riverside, California with a productivity factor of 1.2. Alternatively, merit-shop based labor rates can significantly reduce costs.

5 Base plant design is wet-cooled. The goal of this alternative dry-cooled design is to fix 103 MWe net and 6.3 hours of storage. Therefore, the solar field and steam turbine outputs increased to accommodate the larger parasitic load and lower efficiency in a dry-cooled plant. 


\section{WorleyParsons}

resources \& energy

\section{APPENDIX B}

\section{O\&M COST Estimate SUMmaRY}




\section{Wi] WorleyParsons}

resources \& energy

Project Name: CSP Trough Plant Cost Estimate - Dry Option

Project Desc: $\quad$ 103MWe net with 6.3hrs TES

Location: Daggett, CA

Client: National Renewable Energy Laboratory - DOE

Date:

12/07/09

Revision:

Originator:

B

Reviewer:

D. Ross

R. Bowers

Model Inputs

Est Gas Cost

Est Water Cost

Est Auxiliary Power Cost

\begin{tabular}{|l|l|}
\hline \$MMBtu & $\$ 6.00$ \\
\hline$\$ /$ acre-ft & $\$ 450$ \\
\hline$\$ / \mathrm{kWh}$ & $\$ 0.08$ \\
\hline
\end{tabular}

Field Design

Solar Field Effective Mirror Aperture Area

Net Plant Output to Grid

Annual Net Power Generation

Total Installed Capital Cost

\begin{tabular}{|l|l|}
\hline $\mathrm{m}^{2}$ & $1,062,750$ \\
\hline MWe & 103 \\
\hline MWe-hr & 438,790 \\
\hline$\$$ & $\$ 1,096,751,000$ \\
\hline
\end{tabular}

O\&M Cost Breakdown

\begin{tabular}{|l|l|}
\hline Onsite Staff & $\$ 5,523,450$ \\
\hline Utilities & $\$ 318,960$ \\
\hline Purchased Auxiliary Electricity & $\$ 93,834$ \\
\hline Natural Gas & $\$ 43,606$ \\
\hline Water & $\$ 456,401$ \\
\hline Utilities Sub-Total & $\$ 891,602$ \\
\hline Consumables & \\
\hline Maintenance \& Repairs & $\$ 1,047,173$ \\
\hline Solar Field & $\$ 324,740$ \\
\hline HTF System & $\$ 363,923$ \\
\hline TES System & $\$ 2,369,597$ \\
\hline Power Block & $\$ 4,105,432$ \\
\hline Maintenance \& Repairs Sub-Total & $\$ 87,096$ \\
\hline Chemicals \& Water Treatment & $\$ 110,245$ \\
\hline Office \& Administration & $\$ 84,925$ \\
\hline Training & $\$ 394,413$ \\
\hline Contract Services & $\$ 119,553$ \\
\hline Miscellaneous Cost & $\$ 11,773,118$ \\
\hline $\begin{array}{l}\text { Total Annual O\&M Cost } \\
\text { O\&M Percent of Total Installed Capital Cost }\end{array}$ \\
\hline
\end{tabular}

\section{NOTES}

1 Fixed and variable costs are based on 2nd quarter 2009 US $\$$ projected to 2012 first operating year, based on $3 \%$ annual escalation (including inflation).

2 Water consumption includes WSAC makeup, mirror washing, and steam cycle makeup.

3 Raw and waste water assume no pre or post water treatment, respectively.

4 Maintenance and repairs includes spare parts and labor.

5 Solar collector mirror washing is sub-contracted from June through Sept, washing is done by plant staff for the remaining months. 


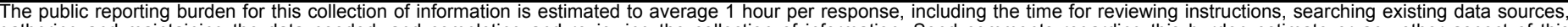

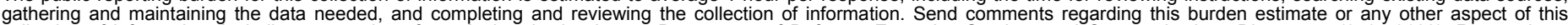

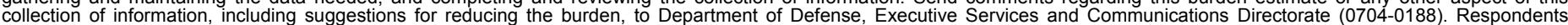

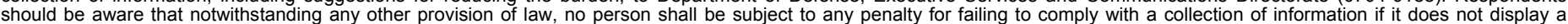

should be aware that notwithstanding

PLEASE DO NOT RETURN YOUR FORM TO THE ABOVE ORGANIZATION.

\section{REPORT DATE (DD-MM-YYYY) July 2010 \\ 2. REPORT TYPE \\ Technical Report}

4. TITLE AND SUBTITLE

Parabolic Trough Reference Plant for Cost Modeling with the Solar Advisor Model (SAM)
3. DATES COVERED (From - To) March 2009-April 2010

5a. CONTRACT NUMBER

DE-AC36-08-GO28308

5b. GRANT NUMBER

5c. PROGRAM ELEMENT NUMBER

5d. PROJECT NUMBER

NREL/TP-550-47605

5e. TASK NUMBER

SS01.2340

5f. WORK UNIT NUMBER

7. PERFORMING ORGANIZATION NAME(S) AND ADDRESS(ES)

National Renewable Energy Laboratory

1617 Cole Blvd.

8. PERFORMING ORGANIZATION REPORT NUMBER

Golden, CO 80401-3393

NREL/TP-550-47605

9. SPONSORING/MONITORING AGENCY NAME(S) AND ADDRESS(ES)

10. SPONSOR/MONITOR'S ACRONYM(S) NREL

11. SPONSORING/MONITORING AGENCY REPORT NUMBER

12. DISTRIBUTION AVAILABILITY STATEMENT

National Technical Information Service

U.S. Department of Commerce

5285 Port Royal Road

Springfield, VA 22161

13. SUPPLEMENTARY NOTES

14. ABSTRACT (Maximum 200 Words)

This report describes a component-based cost model developed for parabolic trough solar power plants. The cost model was developed by the National Renewable Energy Laboratory (NREL), assisted by WorleyParsons Group Inc. for use with NREL's Solar Advisor Model (SAM). This report includes an overview and explanation of the model, two summary contract reports from WorleyParsons, and an Excel spreadsheet for use with SAM. The cost study uses a reference plant with a 100-MWe capacity and six hours of thermal energy storage. Wet-cooling and dry-cooling configurations are considered. The spreadsheet includes capital and operating cost by component to allow users to estimate the impact of changes in component costs.

15. SUBJECT TERMS

CSP; parabolic trough; cost modeling; component-based; Solar Advisor Model; wet cooling; dry cooling; thermal energy storage; NREL; Craig Turchi; WorleyParsons; spreadsheet

\begin{tabular}{|c|c|c|c|c|c|}
\hline 16. SECURITY & CLASSIFICATI & N OF: & 17. LIMITATION & 18. NUMBER & 19a. NAME OF RESPONSIBLE PERSON \\
\hline a. REPORT & b. ABSTRACT & c. THIS PAGE & $\begin{array}{l}\text { OF ABSTRACT } \\
\text { UI }\end{array}$ & & \\
\hline & & & & & 19b. TELEPHONE NUMBER (Include area code) \\
\hline
\end{tabular}

